A PRÁTICA dOS ENFERMEIROS EM POSTOS DE SAÚdE MUNICIPAIS NO ESTADO DO PARANÁ, E SUA RELAC̄̃̃O COM A FORMACÃO PROFISSIONAL E A ORGANIZACÃO DOS SERVICOS

Lilia Bueno de Magalhāes

Tese apresentada à Faculdade de Saúde Pública da Universidade de São Paulo, Departamento de Prática de Saúde Pública, para obtenção do título de Doutor em Saūide Püblica.

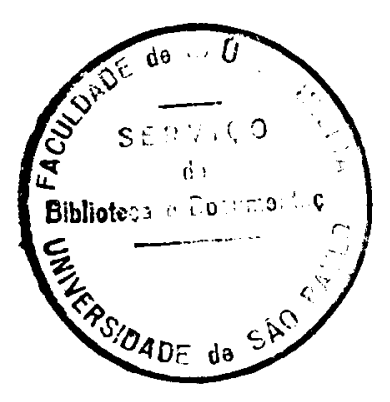

São Paulo 
A PRĀTICA DOS ENFERMEIROS EM POSTOS DE SAUUDE MUNICIPAIS NO ESTADO DO PARANĀ E SUA RELAÇ̃̃O COM A FORMAÇ̃̃ PROFISSIONAL E A ORGANIZAC,̃̃o DOS SERVIÇOS

Lilia Bueno de Magalhães

Tese apresentada a Faculdade de Saüde Püblica da Universidade de São Paulo, Departamento de Prätica de Saúde Püblica, para obtenção do título de Doutor em Saüde Püblica.

Orientadora: Profa Dra. Maria de Lourdes Rodrigues 
Aqueles, que se entregam à prätica sem ciēncia, são como o navegador que embarca em um navio sem leme nem büssola. Sempre a prätica deve se fundamentar na boa teoria.

\section{LEONARDO DA VINCI}


DEDICATÓRIA 
À memöria da minha avó Leonete, com quem convivi até os 13 anos e que, ao receber os pobres pela porta da frente de sua casa em Castro, ensinou-me a voltar o olhar e trabalhar com os espoliados e excluidos. 
AGRADECIMENTOS 
Dra. Maria de Lourdes Rodrigues por sua orientação e autonomia durante todos esses anos.

Rossana Stavie Baduy e Maria do Socorro M. 01iveira que, durante 2 anos e 4 meses, me substituiram e sem os quais seria impossivel a minha saida para os crēditos e a pesquisa de campo.

Leslie V. 0. V. Rego, 0lga Giraldi Paterline, Regina K. T. Souza, Tereza Meiga Pinto, Alci A. L. de Souza, Ezia Maria Corradi e Demerval Nunes da Silva pela presteza com que atenderam a minha solicitação dos currículos e programas das escolas de enfermagem.

Angela P. Cargano e Cilla que transcreveram e datilografaram a maior parte das entrevistas.

Vera Lúcia Ogassawara, do Núcleo de Processamentos de Dados da Universidade Estadual de Londrina, pela programação e digitação dos dados quantitativos.

Marcos Pellicano, bibliotecärio do NESCO/LONDRINA, pela normalização das referēncias.

Cleusa Rocha Asanome, estatīstica do departamento de Matemática da UEL, que dispōs do seu tempo, orientando na confecção de tabelas e no tratamento estatistico.

Idalina Bueno de Magalhāes, minha māe, que com paciēncia revisou o texto.

Ao Programa Institucional de Capacitação Docente - P.I.C.D., que, com sua bolsa, permitiu que tivessemos recursos suficientes para realizarmos entrevistas, viajando de um extremo ao outro do Estado do Paraná.

Aos doutores Nelson Ibanez, Rosa Maria Godoy Serpa da Fonseca, Maria Jacyra de Campos Nogueira, Alice Moreira Derntel e Maria Coeli Campedelli pelas sugestōes.

Aos enfermeiros entrevistados que, dispondo do seu tempo, contribuíram para a discussão de sua prätica e que, em muitos momentos ouvindo as suas palavras parecia que tinhamos compartilhado das mesmas experiēncias apesar de nunca termos trabalhado juntos. 
somio 
PÁGINA

LISTA DE TABELAS E QUADROS

4.1 - Os cursos de enfermagem no Paraná .................... 23

4.1.1. Localização dos cursos ...................... 23

4.1.2. Anālise da disciplina enfermagem de saúde pūblica ...

4.2 - Organização das secretarias ou departamentos de saúde municipais quanto à programaçāo, manual de normas e atribuiçōes da

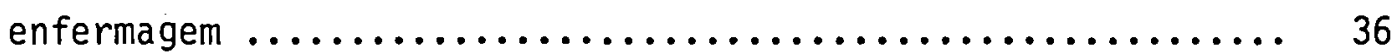

4.3 - Características da população estudada $\ldots \ldots \ldots \ldots \ldots \ldots \ldots \ldots . \ldots . \ldots . \ldots$

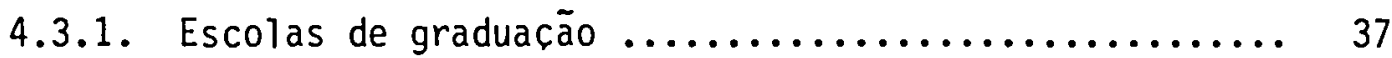

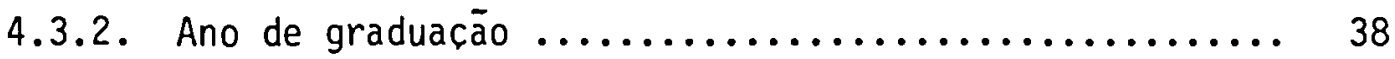

4.3.3. Habilitados em enfermagem de saúde pública segundo Instituições de Ensino .................... 38

4.3.4. Especializados em saüde püblica segundo Instituiçōes de Ensino ................................ 39

4.3.5. Tempo de trabalho nos municipios estudados ........ 40

4.3.6. Carga horäria contratual ................... 41

4.3.7. Horas de trabalho intra e extra-posto de saúde ..... 43

4.3.8. Relação numérica a tendentes/enfermeiras ......... 44

4.3.9. Postos de saúde sob supervisão do enfermeiro ....... 46

4.4 - A prática dos enfermeiros ........................ 47

4.4.1. Atividades administrativas ............... 46

4.4.2. Atividades assistenciais ................. 57

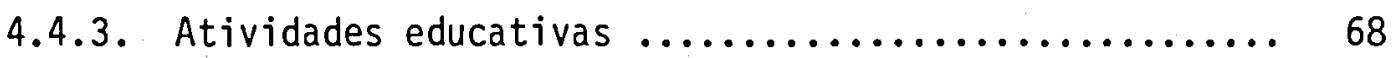

4.4.4. Pesquisa e outras atividades ............... 71

4.4.5. Atividade extra-postos de saúde .............. 73

4.4.6. Clima organizacional e fatores facilitadores do desem penho ................................ 78 
4.4.7. Fatores dificultantes do desempenho ........... 81

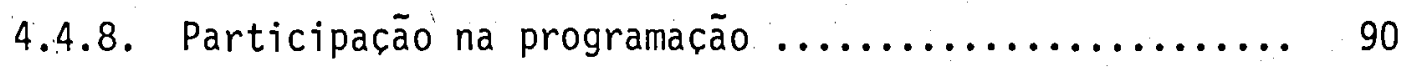

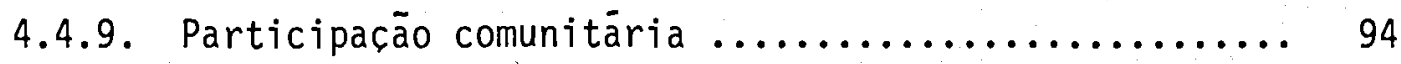

5 - Associação entre as atividades desenvolvidas, a formação profissional e a organização dos serviços ............... 96

6 - Avaliação e sugestões para disciplina de saúde pública ..... 98

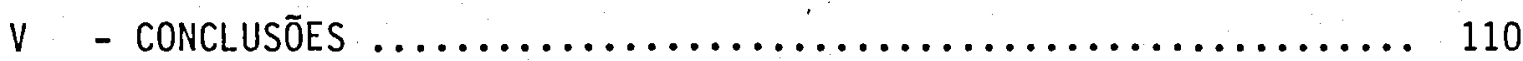

VI $\quad$ REFERÊNCIAS BIBLIOGRĀFICAS $\ldots \ldots \ldots \ldots \ldots \ldots \ldots \ldots \ldots \ldots \ldots \ldots \ldots \ldots \ldots \ldots \ldots$

ANEXOS 
LISTA DE TABELAS E QUADROS 


\section{LISTA DE TABELAS E QUADROS}

PĀGINA

QUADRO № 1 - Coeficientes de Mortalidade Infantil, nos municipios estudados .................................

QUADRO No 2 - Estabelecimentos de Saúde por algumas características, segundo os municípios estudados, Paranā, 1988.

QUADRO № 3 - Distribuiçāo dos cursos de enfermagem, segundo a sua sede, no Estado do Paraná, 1988 .................

QUADRO № 4 - Distribuição da carga horária da disciplina Enfermagem de Saūde Püblica, segundo Escolas de Enfermagem

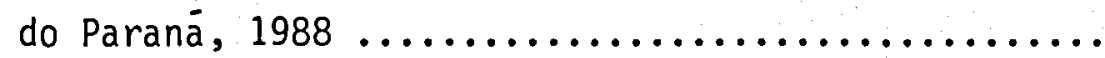

TABELA № 1 - Distribuição quanto a presença ou ausēncia de algumas variāveis organizacionais, em 22 municipios do Estado do Paraná, 1988 ........................

TABELA № 2 - Número e porcentagem dos enfermeiros em postos de saúde municipais, segundo as escolas de graduação,

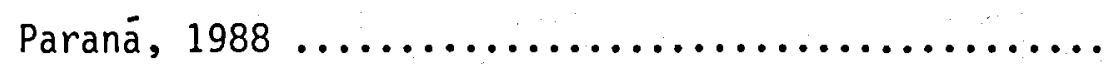

TABELA № 3 - Número e porcentagem dos enfermeiros em postos municipais, segundo ano da graduação, Paraná,..1988 .....

TABELA № 4 - Número e porcentagem dos enfermeiros em postos municipais, segundo cursos de habilitação, em saūde püblica, Paraná, 1988 ..........................

TABELA № 5 - Nümero e porcentagem dos enfermeiros em postos municipais, segundo curso de especialização em saūde pü-

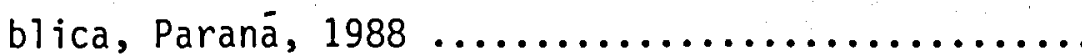

TABELA № 6 - Nümero e porcentagem dos enfermeiros em postos de saüde, segundo tempo de trabalho, Paranā, $1988 \ldots .$.

TABELA № 7 - Número e porcentagem de enfermeiros em postos de saūde municipais, segundo horas de trabalho contrata

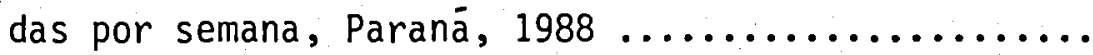

TABELA № 8 - Número e porcentagem de horas de trabalho intra e ex tra-posto de saúde dos enfermeiros, em postos de

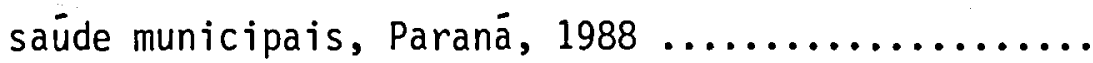

TABELA № 9 - Relação numérica de enfermeiros por atendentes, segundo municīpios e média de atendentes por enfermeiro, Paraná, 1988 
TABELA № 10 - Relação dos enfermeiros, segundo municípios e postos de saúde sob sua supervisão, Paraná, $1988 \ldots \ldots \ldots \ldots .46$

QUADRO № 5 - Nümero e porcentagem de atividades administrativas intra-posto de saúde, relacionadas pelos enfermeiros, em municipios do Paraná, 1988 ...............

QUADRO № 6 - Nümero e porcentagem de enfermeiros que declararam desempenhar atividades assistenciais intra-postos de saúde, em 22 municīios do Paraná, 1988 ...........

QUADRO № 7 - Número e porcentagem de enfermeiros que declararam exercer atividades educativas, segundo 0 tipo de atividade, em 22 municípios do Paranā, 1988 .......

QUADRO № 8 - Número e porcentagem de enfermeiros que executam atividades de pesquisa e outras, intra-posto de saú-

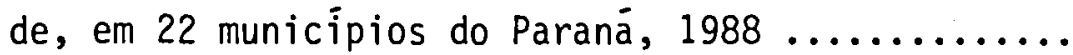

QUADRO № 9 - Número e porcentagem de enfermeiros que declararam executar atividades extra-postos de saúde, em $22 \mathrm{mu}-$

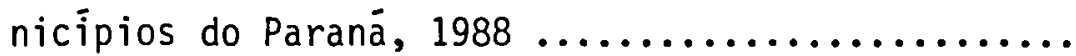

TABELA № 11 - Número e porcentagem de enfermeiros segundo a existência de fatores institucionais que facilitam o desempenho, em 22 municípios do Paraná, 1988 ........

QUADRO № 10 - Nümero e porcentagem de fatores intra institucionais facilitadores do desempenho relacionados pelos enfermeiros, em 22 municipios do Paraná, 1988 .......

TABELA № 12 - Nümero e porcentagem de enfermeiros segundo a existéncia de fatores institucionais que dificultam 0 desempenho, em 22 municīios, Paraná, 1988 ........

QUADRO № 11 - Nümero e porcentagem de fatores intra institucionais dificultadores do desempenho relacionados pelos enfermeiros, em 22 municípios do Paranā, 1988 ........

TABELA № 13 - Número e porcentagem de participação de enfermeiros na programação das atividades de saūde, em 22 muni-

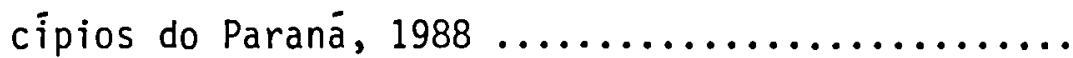

TABELA № 14 - Nümero e porcentagem de enfermeiros em atividades com a comunidade, em 22 municipios do Paraná, 1988 
QUADRO № 12 - Relaçāo entre as atividades desempenhadas por enfermeiros e servicos organizados e não organizados, em 22 municípios do Paranā, $1988 \ldots \ldots \ldots \ldots \ldots \ldots \ldots . . \ldots 6$

QUADRO № 13 - Relaçāo entre as atividades desempenhadas pelos enfermeiros e escolas de graduação, em 22 municípios do Paraná, 1988 ..............................

TABELA № 15 - Nümero e porcentagem de enfermeiros segundo a contribuição teórica no desempenho atual da disciplina de saúde pública, em 22 municípios do Paraná, 1988.

TABELA № 16 - Número e porcentagem de enfermeiros segundo a contribuição do estágio na disciplina de saūde püblica no desempenho atual, em 22 municípios do Paraná, 1988 ..................................... 99

QUADRO № 14 - Nümero e porcentagem de sugestōes para modificação da disciplina de saúde pública dos enfermeiros, em 22 municīpios do Paranä, 1988 ................. 100 
RESUMO 
A expansão do mercado para enfermeiras, em postos de saüde municipais, levou a uma pesquisa para caracterizar a prática desses profissionais em postos de saúde de 22 municipios do Estado do Paranā, e sua relação com a formação profissional e organização dos serviços. São descritos a carga horäria e conteúdo das disciplinas de enfermagem de saüde pública, das 7 escolas de enfermagem do Estado, e a existencia nas secretarias ou departamentos, de programas, atribuicões dos enfermeiros e auxiliares de saúde, manual de normas e procedimentos. Foram entrevistados 117 enfermeiros. A população estudada apresentava como características: ter menos de 5 anos de formada $(65,8 \%)$, trabalhar no municipio hä menos de 2 anos $(58,9 \%)$ e com uma carga horāria contratual em maior proporção de 40 horas semanais $(47,9 \%)$; o nümero de enfermeiros com formação específica na área era baixo: habilitação em saúde pública $16,3 \%$ e especialização em saūde pública $28,0 \%$. Tinham sob sua supervisão em média 2.1 postos de saúde e 8.4 auxiliares de saüde. A frequência maior entre as atividades administrativas foi a supervisão $(76,0 \%)$; nas assistenciais 0 atendimento de enfermagem $(83,7 \%)$ e nas educativas o treinamento de pessoal $(50,4 \%)$. A atividade de pesquisa apresentou baixo percentual $(4,2 \%)$. As reuniões em nivel central foram as mais frequentes entre as extra-posto de saúde. 0s fatores facilitadores do desempenho foram o relacionamento inter-equipe, 0 apoio institucional e a autonomia e entre os dificultadores a planta física, insuficiēncia de recursos humanos e capacitação insuficiente. Não participavam da programação $23,1 \%$ e as atividades com a comunidade foi referida por $56,4 \%$ dos entrevistados. Foi avaliado insuficiente o conteúdo teörico e prätico da disciplina enfermagem de saúde pública e as sugestões foram para mudanças no conteúdo, carga horäria, alocação e integração com outras disciplinas. Os egressos da escola de Enfermagem da Fundação Universidade de Cascavel (FECIVEL) foram os que apresentaram diferencas significativas entre as atividades desenvolvidas em relação às outras escolas. As atividades de supervisão e treinamento de pessoal apresentaram uma forte evidéncia de que a proporção dos enfermeiros, que desempenham estas atividades nos serviços organizados, é maior que nos serviços não organizados. As atividades com a comunidade e a participação na programação mostraram-se não associadas à organização, sugerindo que as va riāveis selecionadas para compor o indicador serviço organizado, parecem ser inadequadas para esta associação. 
SUMTARY 


\section{SUMMARY}

This research was meant to verify the practice of professionals in health units of 22 municipalities in the state of Parana. The amount of hours and subject matter content in the public health nursing courses of seven state schools, the availability of health programs in government departments, the duties of nurses and health assistants, and the manual of norms and procedures were checked and presented in this work. 117 nurses interviewed had the following characteristics: less than five years of graduation $(65.8 \%)$, less than two years job experience in the municipality (58.9\%), 40 hour weekly work $(47.5 \%)$. The nurses with a specialized field of studies in public health $(28.0 \%)$ had under their supervision an average of 2.1 health units and 8.4 health assistants. Supervision scored highest within administrative work $(76.0 \%)$, nursing scored $83.7 \%$ as an assisting work. Within the educational work, personnel training scored $50.4 \%$ whereas the research work scored only $4.2 \%$. Among out-of-the-health unit activities, meetings were the most frequent. Facilitating factors of performance were inter-teams relationship, institutional support and autonomy. The impeding factors were the area plan, the lack of human resources and qualification. $39.3 \%$ of the informants did not engage in any community program. The theoretical and practical content of the public health nursing course was considered insufficient by $33.2 \%$. Suggestions were given as to content, disciplines and amount of hours in the course. The nurses graduated in Faculdade de Educação, Ciencias e Letras in the city of Cascavel (FECIVEL) presented significant differences as to their formation and professional practice compared to graduates from other schools. Nevertheless, similarities were found in terms of community participation by graduates from Universidade Federal do Paraná, participation in programs by those from Universidade Católica do Paraná and Centro de Estudos Superiores de Londrina (CESULON), and personnel training by those from Universidade Estadual de Londrina. The relation between practice and organized services also presented differences as to supervision and training. And activities with the community and participation in programs were seen as independent variables in the organization of health services. 
I. I N T R O DU C A 0 


\section{INTRODUCĀO}

A enfermágem de Saúde Püblica, sendo uma prätica social, reflete as mudanças que ocorrem na sociedade e na assistēncia à saúde.

A constituição histörica do saber e da prätica na enfermagem durante o periodo de 1920-1983, foi muito bem descrita e analisada por SILVA $^{115}$ e ALMEIDA \& ROCHA ${ }^{6}$. Para os dois ültimos autores, há dois direcionamentos futuros para a enfermeira profissional: 0 primeiro, seria a ampliação de suas funçōes onde ela exerceria algumas atividades médicas, no cuidado direto do paciente, podendo ser chamada de primarista; o outro seria um aprofundamento do seu próprio campo do saber, convertendo-se em um especialista de atenção de enfermagem.

0 primeiro desses direcionamentos (o papel ampliado da enfermeira) surge no bojo das propostas de extensão de cobertura, a ser alcançada atravēs da estratégia de atenção primäria de saúde (APS).

Essas propostas tēm a sua emergēncia em programas de Medicina Comunitária, nos EEUU, na década de 60 , e é uma solução encontrada pelos países capitalistas para a crise da Medicina científica, por meio de implantaçāo de um modelo que incorpora proposiçōes como: aumento da produtividade com a diminuição de custos, simplificação de servicos e participação comunitāria.

A consolidação definitiva da APS ocorre em 1978, na Conferēncia de Alma-Ata, em que "um dos principais objetivos sociais dos governos, das organizaçōes internacionais e de toda a comunidade mundial, no curso dos próximos decénios, deve ser o de que todos os povos do mundo alcancem, no ano 2.000, um nivel de saúde que lhes permita. levar uma vida social e economicamente produtiva. A atenção primāria de saúde è a chave para alcancar esta meta como parte do desenvolvimento, conforme o espirito de justica social" 34 .

A enfermeira encampa estes objetivos na conferéncia realizada pela OMS, em 1981, intitulada "Enfermagem em apoio à meta Saúde para todos no ano 2.000", propondo a ampla utilização de pessoal elementar de enfermagem na prestação de serviços básicos de saúde, com delegáąão de funçōes ${ }^{6}$.

Essa delegação de funçóes pode ocorrer tanto com o objetivo de desmonopolização do saber (que sō poderā surgir de uma relação dialētica entre os discursos dos profissionais de saúde e da população), como também ser apenas uma transferéncia linear de certos conhecimentos e habilidadis.

A Organização Panamericana de Saúde 95 e vários autores $^{28}, 30,76,93,97,101,106,110$ entendem que o papel ampliado do en- 
fermeiro, em APS, seria desempenhar as funcōes para as quais tradicionalmente tem sido preparado: administraçāo de serviços, planejamento, supervisāo, avaliação, educação e novas atividades como, por exemplo, preparar histōrias clinicas, estabelecer diagnósticos, instaurar tratamentos, incorporar os membros da comunidade na tomada de decisōes em relação à provisāo e avaliaçāo dos serviços. A prestação de cuidados diretos pelo profissional tem sofrido criticas e restriçoes, no Brasil, com diferentes argumentos.

Para VIEIRA ${ }^{127}$, "é impraticável pensarmos o profissional de enfermagem dedicado à prestação direta de assisténcia... Enquanto não se alterar significativamente a disponibilidade de enfermeiros no pais, o emprego mais racional de sua capacidade impõe que ele seja antes um profissional multiplicador, coordenador, supervisor, docente, que um prestador direto de servicos".

SILVA 115 afirma que, "na sociedade brasileira atual, está reservado um lugar para as enfermeiras na divisão social do trabalho, que diz respeito, sobretudo, ao desempenho de atividades administrativas e de ensino. Estas atividades constituem o objeto de trabalho, por exceléncia, das enfermeiras, hoje, no Brasil".

A enfermagem primarista, que preconiza o cuidado direto ao paciente, ainda é idealista e, nesta proposta, caberia ao enfermeiro desempenhar as atividades de treinamento e supervisão do pessoal auxiliar ${ }^{6}$.

E no Paraná, qual seria a prática em APS destes profissionais? Dois municípios são pioneiros em prestar serviços básicos de saúde, nos moldes preconizados pela assistēncia primäria de saúde: Londrina e Cambé, ambos localizados no Norte do Paranā.

Dada a relevāncia destas experiéncias em relação ao tema deste trabalho, passamos a descrever suscintamente suas principais caracteristicas.

A experiēncia de Londrina orientou-se pelas diretrizes da Medicina Comunitária: descentralização, hierarquização de serviços e participação de serviços e participação da população. Implantada a partir de 1977, diferia de outras propostas existentes na época, como o PIASS, pois desenvolvia-se em ärea totalmente urbanizada, com elevada concentraçāo de capital e-complementar a organização médica, isto é, desenvolvendo-se em uma ärea fora do interesse dos grupos privados ou cooperativas médicas 37 .

Os auxiliares de saúde, além de ações de enfermagem, como vacinas, prē-consulta, pós-consulta, desempenhadas em serviços de saúde püblica, jassam a incorporar em sua prática o que passou a se denominar patologias delegadas, isto é, o atendimento à doenças comuns, de fäcil diagnóstico e tratamento, tais como: verminose, piodermites, escabiose, 
gripes, dermatites amoniacal e seborréica, granuloma umbilical e outras, em programas desenvolvidos em postos da Universidade Estadual de Londrina. 0 municipio de Cambé, a partir de 1975, por iniciativa de alguns profissionais que atuavam na rede, implementava algumas medidas para melhorar a estrutura do serviço püblico municipal, mas, sem o apoio do Executivo e nem mesmo do chefe de Departamento de Bem Estar Social, estas medidas foram esvaziando-se. Em 1982, com uma nova administração, passouse a reestruturar o sistema local de saúde, priorizando a organização da rede primāria de atenção à saüde, enquanto porta de entrada do sistema e, ao mesmo tempo, estimulando a organização da população ${ }^{74}$.

$\mathrm{Na}$ ärea de enfermagem de saüde püblica, os dois municípios, em 1987, apresentavam, quanto à composição dos recursos humanos e atribuiçōes dos enfermeiros, a conformação abaixo descrita:

\section{a) Londrina}

A rede contava com 12 enfermeiras e 59 auxiliares de saúde, alocados em 28 postos.

A atuação dos enfermeiros se dava em dois niveis: local e central, e as atribuicões, descritas por ZAROUR e col. ${ }^{130}$, compreendiam:

\section{Nivel Local}

1.1. Atuar conjuntamente com o auxiliar de saúde no atendimento $\bar{a}$ populaçāo, no sentido de entrar em contato com a comunidade $e$ seus problemas e de aplicar e desenvolver conhecimentos adquiridos.

1.2. Supervisionar os postos: planejar, programar atividades dos PS; organizar internamente o PS; treinar o auxiliar de saüde; fazer educação continuada; avaliar o serviço e o desempenho técnico dos auxiliares de saúde; prover e controlar materiais e medicamentos; realizar e coordenar reuniōes internas no PS.

\section{Nivel Central}

- Planejar e operacionalizar cursos de formaçāo, reciclagem e treinamento em serviços para os auxiliares de saüde $(A E)$;

- Elaborar projetos de avaliação do auxiliar de saúde;

- Reformular elou elaborar rotinas e normas administra-

tivas;

- Participar de reuniōes científicas e técnico-administrativas com os enfermeiros;

doenças transmissiveis;

- Elaborar relatōrios, projetos gerais e notificar as

- Desenvolver trabalhos científicos;

- Colaborar com outras instituiçōes no planejamento e execuçāo das atividades pertinentes $\bar{a}$ saūde. 


\section{b) Cambē}

Os recursos humanos, em janeiro de 1987, compreendiam 5 enfermeiros e 27 auxiliares de saúde alocados em 5 postos de saúde e 1 Centro de Saüde Integrado.

SOUZA ${ }^{120}$, relatando a atuação dos enfermeiros na rede básica, referencia "2 objetivos da equipe para o trabalho:

10) Estabelecer um bom serviço de atendimento à saūde, que contribua efetivamente, dentro dos limites possiveis, para a melhoria das condiçōes de saūde da população, atravēs da resolução dos seus problemas mais concretos $e$ imediatos;

20) Estabelecer um nivel de atuação que use a participação, a conscientização e organização popular, tanto no que diz respeito às questōes específicas de saūde, ou lutas pelas melhorias imediatas no bairro, assim como em questões politicas mais gerais, de luta pela democratização do país e por transformaçōes profundas na sociedade brasileira.

0 enfermeiro atua em dois niveis nessa rede:

1. Administrativo - reuniōes para discussão de questōes gerais com a equipe, $e$ as especificas de enfermagem.

2. Unidades de Saūde - 0 enfermeiro tem papel fundamental na supervisão e coordenação das atividades desenvolvidas ... Dentro desta linha estamos discutindo constantemente com os auxiliares, visando dar continuidade ao processo de capacitaçāo ...

Devemos também desenvolver assistência direta, visando ao aprimoramento, à supervisão e ao contato com o cliente.

o trabalho com a comunidade ainda engatinha, estamos desenvolvendo-o na base de tentativas. Apesar disso, consideramos fundamental entender cada dia mais a comunidade em que atuamos, conhecendo os seus problemas especificos e, em qualquer situação, nāo perder a consciencia da questão mais geral, que $\bar{e}$ a principal determinante dos problemas de saúde da população".

Nos dois municipios, as atribuicōes dos enfermeiros, em sua maioria, nāo diferem das atividades classicamente propostas para a enfermeira de saúde pública e desenvolvidas em serviços estaduais, comumente, fazendo parte das propostas curriculares de escolas de enfermagem do pais $^{90,91 .}$

A àrea de recursos humanos vem sendo reconhecida como um elemento crítico para alcançar a reorientação e transformação dos sistemas de servicos de saúde e do profissionais. Existe tendéncia de se enfocar de forma mais integral a problemātica de Recursos Humanos ${ }^{7}, 56,68$.

A OPAS ${ }^{100}$ propōe, considerando a transcendéncia dos recursos humanos, o seguinte diagrama para estudos na área: 


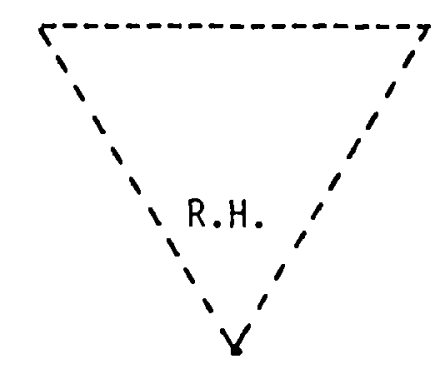

Estado, Corporações e Empresas

Processo de Trabalho

Hä divergēncias quanto a importāncia relativa de cada um desses atores: o sistema educacional, as corporações e as empresas püblicas e privadas que absorvem essa forca de trabalho. As mudanças no sistema educacional passam pelo conhecimento das condicões concretas do trabaTho. 0 aparelho formador deve responder não só ao mercado de trabalho, mas às necessidades de saúde da população. As diretrizes politicas do Estado brasileiro vēm sofrendo transformacōes que se refletiram na expansão de serviços de saúde municipais e, em consequéncia, na absorção de enfermeiros para prestarem assistência básica de saūde.

Essas mudanças iniciam-se com a criação do Conselho Consultivo de Administração de Saüde Previdenciäria - CONASP (decreto no 86.329 de 02/09/1981) e aprovação do Plano de Reorientação da Assisténcia à Saúde no àmbito da Previdēncia Social (Portaria no 3.602 de 23/08/1982) que, entre as linhas de ação básica, propunha-se a maior e melhor utilização da rede pública de serviços básicos de saūde, através da implantação do "Convênio Trilateral "Ministērio da Previdēncia e Assistēncia à Saúde, Ministério da Saūde e Secretarias Estaduais de Saūde, substituīdo posteriormente pelas Ações Integradas de Saúde (AIS). Os primeiros convênios foram assinados em 1983, criando-se comissöes interinstitucionais como mecanismos de gerēncia dos serviços públicos em processo de integração 3 .

A racionalização das açōes se daria com a unificação dos recursos e servicos e as AIS se efetivaram através desses convénios entre os Ministērios, as Secretarias Estaduais de Saūde e os municípios.

o Paraná foi um dos últimos Estados a assinar o convénio, em 22 de fevereiro de 1985, inicialmente envolvendo unidades de saüde de 13 municīpios: Curitiba, Araucāria, Campo Largo, Ponta Grossa, Guarapuava, Cascavel, Foz do Iguaçu, Maringā, Londrina, Cambē, Ibiporā, Francisco Beltrão, Toledo e, em dezembro de 1986 , os restantes 278 , dos 311 municipios paranaenses existentes nessa época.

As AIS passam a ser uma estratégia transicional, com o objetivo de fortalecimento do setor público, descentralização, revisão do financiamento setorial, mudança rádical nas relaçoes entre o setor püblico e privado, universalização e equalização do atendimento, tornando-se 
instrumento fundamental na constituição dos serviços municipais de saúde ${ }^{3}$.

Os municipios, com 0 aumento do repasse financeiro, passam a ampliar a rede de postos de saúde e a contratar enfermeiros e auxiliares de saüde.

A municipalização dos serviços è antiga proposta do Ministério da Saúde (MS), como foi apresentada por SILVEIRA 117 na III Conferēncia Nacional de Saúde: "Defendendo o Ministério da Saúde o princípio de que os servicos locais são de responsabilidade dos municípios, é evidente que não poderia estabelecer normas de organização para os mesmos... Uma organizaçāo central, programando em um pais continental, planos e programas para realização local, nos diferentes municípios do Brasil, é um verdadeiro contra-senso. As populaçōes locais é que podem ter um conhecimento mais realista dos seus problemas, são elas que devem sentir o que deva ser atendido prioritariamente."

Segundo DALLARI ${ }^{41}$, "o estabelecimento de organização sanitāria com base municipal interessa nāo sō ao governo, que deseja manter-se no poder com o apoio da população, como também ao próprio Estado que, ao satisfazer as necessidades de saúde de seu povo, promove a lealdade política de seus membros".

Os municipios brasileiros têm se empenhado neste projeto, como demonstram os värios encontros municipais do setor saúde e dos secretārios municipais $25,33,96,103,112$.

CORDONI ${ }^{39}$, ao analisar as tendéncias e perspectivas dos serviços municipais no Paraná, recomenta a que o Estado repasse para alguns municipios os seus servicos de APS.

A implantaçāo das AIS no Estado, entretanto, vem se dando de maneira bastante ortodöxica.

ALBUQUERQUE $^{4}$, por exemplo presidente do Sindicato dos Enfermeiros do Paranā, afirma que "Presenciamos um início da participação efetiva da enfermagem na politica de saüde dos municípios... Entretanto, a enfermagem, que representa $60 \%$ dos recursos humanos mobilizados pelas AIS e que realiza $70 \%$ das açōes de saüde, nāo tem o mesmo peso no que concerne aos postos de decisāo na politica de saūde. Por exemplo: questionamos as portarias do INAMPS nos $314 / 85$ e 45/84; a primeira só considera a consulta médica, a odontológica $e$ a dos profissionais de saüde mental, discriminando os outros profissionais. E a outra atribui a uma ünica categoria a competencia de auditorar as outras. Esta decisão reflete o autoritarismo e a ditadura que, vergonhosamente, uma ünica categoria profissional de saūde exerce frente as outras. Posicionamo-nis contra a politica de pagamentos por açōes prestadas, pela centralização dos recursos e pelos convērios que não visem a universalização do atendimento". 
Para a autora acima citada, alēm de uma sērie de dificuldades emergenciais, que impedem a consolidação das AIS no Paraná (heteronomia salarial, falta de apoio diagnósticoe terapéutico, inexisténcia de sistema de referéncia) esta situação è "agravada na enfermagem considerando:

- falta de posicionamento da enfermagem frente à politica nacional de saūde;

- formação do enfermeiro voltada para a saúde individual;

- ensino profissional avalizando a neutralidade da enfermagem frente à discussão crítica das políticas de saúde. Ex. pouca participação dos docentes em encontros técnicos políticos;

- falta de participacão das entidades de classes: Sindicato, ABEn, na formação do enfermeiro."

A valorização da atuação do enfermeiro era reconhecida pela Associação dos Municípios do Médio Paranapanema (AMEPAR) ${ }^{33}$ que sugere "como uma das formas de apoio técnico para a implantação da rede básica, contratar e colocar enfermeiros sanitaristas em cada cidade pólo, que englobe determinada regiāo, a qual teria a funcāo de ser o ponto de partida para a criação da equipe de saúde".

Em 1986, a 8ạ Conferência Nacional de Saúde consagra a concepcão de um Sistema Único de Saūde que deverá reger-se, em relação à organização dos serviços, pelos princípios da descentralização na gestão dos serviços, integralização das açōes superando a dicotomia preventiva-curativa, regionalização, hierarquização e participação da população no planemento, gestão, execução e avaliação das açōes de saúde; quanto às politicas de recursos humanos, propōe a isonomia salarial, capacitação e reciclagens permanentes, admissão através de concurso püblico, estabilidade no emprego, composicão multiprofissional das equipes, compromisso dos servicos com os usuários, incentivo à dedicação exclusiva, formação de profissionais de saúde integrados ao sistema de saúde e incorporação de agentes de saúde como pessoal remunerado, sob a coordenacão do nivel local do sistema Único de Saūde, para trabalhar em educação para a saūde e cuidados primärios ${ }^{60}$.

A Comissão Nacional de Reforma Sanitäria criada para propor a nova lei do Sistema Nacional de Saúde, considerando as distorcōes existentes entre os trabalhadores de saúde (como os baixos salários e a inadequada regiāo entre a formação e a utilização do pessoal), indica medidas que deverão ser tomadas (como o estabelecimento do regime de tempo integral, real integração entre ensino e serviço em todos os niveis de escolaridade), de forma a se evitar que os servicos arquem com a responsabilidade de capacitação profissional e, em todos os niveis, preconiza um esforco no sentido de aumentar o desempenho quantitativo e qualitativo dos 
mesmos.

Em julho de $1987^{123}$, è criado o Sistema Unificado e Descentralizado de Saúde (SUDS), com a justificativa para a consolidação e desenvolvimento qualitativo das Açōes Integradas de Saúde, significando, que os servidores do INAMPS se incorporam à rede estadual e/ou municipal e o conjunto de recursos (pessoal médicos e equipamentos) passam a ser considerados globalmente, com geréncia única e remuneração equiparada. A responsabilidade de incorporação das diretrizes inovadoras é tanto do apareTho formador como dos servicos que os absorvem.

No ensino convencional, a formação profissional está sempre em descompasso com a prática profissional, de tal maneira que a empresa ou os serviços devem ser responsáveis pelo treinamento, isto é, pela qualificação do tralhador.

Para a qualificação dos enfermeiros, o Paraná contava com sete escolas de enfermagem. No sentido mais estrito, o ensino de novas tec nologias que respondam às mudanças preconizadas, tanto ao nivel da assisténcia sanitāria primária como das políticas governamentais, deveriam estar sob a responsabilidade da disciplina Enfermagem de Saúde Pública e outras afins (como a Epidemiologia e Sarieamento).

A transformação do saber adquirido nas escolas para uma qualificação, que permita o exercício concreto da profissão, necessita que os serviços de saúde contem com um mỉnimo de estrutura organizacional que assegure o desenvolvimento dos seus recursos humanos. KURCGANT ${ }^{63}$ considera que as instituicões de saüde no Brasil apresentam, em sua grande maioria, uma estrutura tīpica das escolas cientificas e clássicas e segundo ALVES $^{8}$, "A organização do trabalho na enfermagem ainda se rege pela administração cientifica proposta por Taylor, com a descrição das tarefas.

Como consequéncia dessa estrutura, as organizaçōes se utilizam, tanto a nível hospitalar, como em saúde pública, do Manual de Normas, Procedimentos e/ou Rotinas. 0 Manual de Normas ou parte dele è um instrumento de informação e, segundo SILVA ${ }^{116}$ torna-se necessário, quando os membros da equipe de enfermagem começam a perder a visão do conjunto, a desconhecer as atividades e finalidades do servico de enfermagem e de outros setores, a ter dūvidas sobre os procedimentos específicos, sobre a autoridade dos elementos e sobre a responsabilidade de cada um".

Outro instrumento ou tēcnica preconizada e bastante difundida nos servicos de saúde é a programação que, no nível operativo, no caso dos postos, são os programas de saúde. Os programas são a expressão do planejamento dos, niveis de direcão. Para NALICK ${ }^{69}$, "programar é condição necessária para tentar diminuir o grau de incerteza com o qual se lida no. cotidiano e é uma técnica que está relacionada diretamente com comparti- 
Thar o poder."

Sem essas condiçōes minimas, (Manual de Normas e Procedimentos e/ou Rotinas, incluindo-se as atribuiçōes dos elementos da equipe de enfermagem - e um programa a ser cumprido) é quase impossivel se atingir algum objetivo, ter algum grau de ordem.

Se ao enfermeiro cabe o controle do processo administrativo, como parte de sua prática, isso dar-se-à de forma mais eficiente se a organização estruturar-se com pelo menos os 3 elementos acima descritos.

Evidente que só esses elementos não são suficientes para se estabelecer resultados administrativos desejados, e outras variáveis externas e internas aos servicos intervēm no processo. Nesse estudo, mais dois fatores relacionados à estrutura da organização e que se refletem na prática profissional foram pesquisados: a participação dos enfermeiros na programação e a percepção do clima organizacional como fator que favorece ou dificulta o desempenho.

A participação na programação dos sistemas locais de saūde faz parte das propostas apresentadas anteriormente, como a assisténcia primária de saúde, passando pelas diretrizes do SUDS e SUS, com a implantação de um modelo de planejamento ascendente e o controle do usuário na gestão através dos conselhos locais de saüde.

A idéia da participação não è nova e, segundo MENDON$C A^{80,81}$, o interesse pelo tema aumenta a partir da Segunda Guerra Mundial, quer seja nas organizações, quer nos meios acadēmicos ou nos países.

As vantagens e desvantagens para a organização dessa prática podem ser resumidas na tipologia de WALKER, apud MENDONCA ${ }^{81}$ : maior/menor eficácia, redução da alienação, democracia, cooperação e atenuação dos conflitos, maior satisfação dos trabalhadores, intrusão nas prerrogativas de direção.

Os graus de participação dos dirigentes e membros no processos de planejamento e de tomada de decisão vāo da informaçāo/reação, consulta facultativa, consulta obrigatōria, elaboraçāo/recomendação, cogestão até a auto-gestão segundo BRANDĀO apud MENDONCA 81 .

0 enfermeiro, como responsável técnico da equipe de enfermagem e muitas vezes chefe do posto de saúde, deveria participar da elaboração dos planos, dos programas, do estabelecimento de estratégias, da avaliação dos resultados, mas, frequentemente, as decisões são apenas "informadas" e, portanto, os profissionais são destruídos de qualquer poder no seu trabalho.

Um aspecto fundamental da paríicipaçāo para o desenvolvimento dos sistemas locais é o apıio aos processos de participacão social, viabilizando o entendimento entre os atores comunitários e institucionais. 
0s agentes institucionais resistem a alterar a rotina e incorporar as diretrizes políticas (como a integração e participação popular). Ou então, permeiam entre os técnicos concepçōes como o uso da popuiação na producãa de serviços, com o fim de baratear os custos e que, segundo BARRENECHEA e col. ${ }^{13}$, leva os postergados a desempenharem atividades, que não são exigidas aos grupos ma is privilegiados, resultando no agravamento das desigualdades.

0 clima organizacional é preocupacão há seis décadas dos gerentes. As condicões de trabalho percebidas pelos trabalhadores em relação à instituição ou ao seu prōprio trabalho podem, segundo PILARES ${ }^{98}$, estar relacionadas a: quantidade de trabalho (quantidade atribuida ao funcionário, distribuicão do trabalho existente na unidade e a suficiēncia do pessoal para a realização dos serviços), relações intersetoriais, sistemas e canais de comunicacão, remuneração e carreira, benefícios, relacionamento com a chefia, relacionamento interpessoal, valorização profissional, motivação e satisfação com a empresa.

Para esse mesmo autor, não se pretende medir a realidade tal qual ela é, mas sim como è percebida, havendo influéncia dos aspectos psicológicos individuais que, por sua vez, são influenciados pelos aspectos organizacionais.

Värios estudos, enfocando esse conjunto de variāveis intervenientes, tēm sido realizados na enfermagem americana, em função dos problemas de alta rotatividade e os efeitos advindos com a perda da eficiência e custos altos.

As pesquisas nessa àrea analisam a associação da satisfação no trabalho com autonomia, reconhecimento pela qualidade do cuidado prestado, apoio da supervisāo, interação grupar, compensação financeira.

BONJEAN e col. ${ }^{16}$ consideram as caracteristicas intrinsecas (que incluem autonomia, responsabilidade e sentimentos de sucesso) como mais importantes que os fatores extrinsecos (tais como as facilidades físicas, benefícios e até mesmo salärio).

CAVANAGH $^{27}$, revisando as pesquisas sobre a rotatividade, apresenta um modelo adaptado de PRICE \& MUELLER, em que a satisfação no trabalho estā relacionada com a participação, promoçōes, comunicação instrumental, rotinização e a intenção de permanência com treinamento, pagamento, oportunidade e encargos.

CARMEL et col. ${ }^{24}$ mostram que os enfermeiros, quando têm oportunidade de definir seus próprios papéis, utilizando-se fostás sagexpriência, conhecendo a sua habilidade, sentem uria melhora em/šia simagemoprofissional, que è expressa pela sacisfação no irabalho. DI LASCI0 43 avaliou a satisfação das necess diades psicosse- 
ciais dos entermeiros em hospitais do Recife considerando os itens: autoestima, autoridade, crescimento e desenvolvimento, prestígio dentro do hospital, ação independente, segurança na posição, auto-realizacão, prestígio fora do hospital, salário, realização no trabalho, ajudar outros, estabelecer objetivos, determinar métodos, estar informado, amizades profundas. Os resultados dessa pesquisa indicam que as enfermeiras "em niveis administrativos inferiores percebem maiores deficiencias na satisfacão das necessidades psicossociais do que as enfermeiras nos niveis administrativos mais altos e particularmente a autonomia é uma das āreas mais críticas na satisfação das necessidades."

0 estudo COFEN/ABEN ${ }^{35}$ encontrou, entre os dez fatores considerados como de muita importāncia para maior eficiēncia e satisfação no trabalho de enfermagem nos estabelecimentos de saúde, por ordem decrescente, os seguintes: a existéncia de creches, programas para melhorar o inter -relacionamento da equipe, incentivo salarial por mérito, material básico em quantidade, pessoal suficiente para cobrir licenças ou férias, refeicões a precos módicos, trabalho interdisciplinar com efetiva participação dos diferentes profissionais no planejamento, execução e avaliação dos programas, transporte para o trabalho de enfermagem na comunidade, equipamentos necessärios e em bom estado de funcionamento, oferecimento regular pela Instituição de cursos para aperfeiçoamento e atualização do pessoal.

Esse estudo, com dados colhidos em todo o território nacional e com a finalidade de conhecer as condiçōes em que se exerce a prática da enfermagem, quem a exerce, em que condicões a exerce e quais os obstáculos encontrados no desempenho profissional, abrangeu os estabelecimentos de saūde e örgãos governamentais de nível central, excluindo desse universo os enfermeiros que atuavam em nivel local nos municípios.

No Paraná, a expansão da rede de postos de saūde sob a responsabilidade dos municipios sofreu grande incremento, passando de 50 em 1983 para 1.005 em $1987^{46}$.

Esse mercado em expansão para os enfermeiros e a inserção da autora no processo de formação em curso de Enfermagem da Universidade Estadual de Londrina levou-a a pesquisar essa fracão da realidade, ainda não estudada no Estado. 
II. $O B$ JET I $\vee O S$ 


\section{OBJETIVOS}

\subsection{Geral}

Esta pesquisa. se propõe a analisar a prätica dos enfermeiros em postos. de saúde municipais no Estado do Paraná, e a sua relação com a formação em Enfermagem em Saúde Pública e a organização das Secretarias ou Departamentos de Saúde Municipais, utilizando-se como referencial a inter-relação, proposta pela OPAS ${ }^{100}$, para estudos de recursos humanos, (o sistema formador, o processo de trabalho e o papel do Estado, Corporacōes e Empresas).

\subsection{Especificos}

2.2.1. Caracterizar a população estudada segundo o tipo de formação acadêmica em nível de graduação, habilitação e/ou especializacão em Saūde Püblica;

2.2.2. Caracterizar a população estudada segundo alguns parámetros quantitativos relacionados ao trabalho nos serviços de saüde;

2.2.3. Caracterizar as atividades exercidas pela população estudada nos serviços de saúde;

2.2.4. Classificar os serviços de saúde quanto à sua organização, tendo como parámetro a existéncia ou não de programas, atribuiçōes do enfermeiro e do auxiliar de saúde e Manual de Normas e Procedimentos;

2.2.5. Caracterizar os fatores organizacionais que facilitam e os que dificultam a prātica dos enfermeiros em tais organizações e

2.2.6. Verificar a relação existente entre algumas atividades de enfermagem e a escola onde o profissional concluiu o curso de graduação;

2.2.7. Verificar a relação existente entre algumas atividades de enfermagem, e a organização dos serviços:

2.2.8. Confrontar a adequaçāo das disciplinas relacionadas à Enfermagem de Saúde Pública oferecidas nos vários cursos de graduação e a opinião dos enfermeiros em relação àsmesmas, tendo em vista se ofereceram referencial teórico-prático para a resolução das dificuldades comuns encontrados no trabalho diário nos serviços de saüde. 
III. MATERIAL E MÉTODO 


\section{MATERIAL E MÉTODO}

\subsection{Local de Estudo}

0 estudo foi realizado em 22 municipios do Paraná, sendo que o critério de escolha desses municípios será discutido adiante, no item 3.2. População. Esse Estado brasileiro situa-se na região sul do País, e tem 323 municipios. A populaçāo em 1980 era de 7.630 .466 e o seu crescimento na década de 70/80, foi um dos mais baixos do país: $0,96 \%{ }^{39}$.

A proporção de população urbana passou de $36,40 \%$ em 1970 para $58,60 \%$ em 1980. Houve um esvaziamento populacional dos municípios, pois $59,66 \%$ tiveram suas populações diminuidas; $25,52 \%$ cresceram à taxas inferiores à médiageométrica brasłleira $(2,84 \%)$ e apenas $14,82 \%$ tiveram aumentos populacionais acima da taxa brasileira na década. Nos municipios estudados tiveram crescimentos acima da média brasileira: Almirante Tamandaré, Foz do Iguaçu, Guarapuava, Maringä, São José dos Pinhais, Araucāria, Cambé, Cascavel, Curitiba, Londrina, Piraquara. Os inferiores à média foram Campo Mourão, Ibiporã, Jaguariaíva, Rio Branco do Sul, Toledo, Apucarana e não cresceram Rolāndia, Ponta Grossa, Palotina e Campo Mourão.

A população projetada para 1986 e 1988 encontram-se em anexo nํ. 2 .

Os coeficientes de Mortalidade Infantil, um indicador sensível do nível de saúde, no ano estudado, estão abaixo relacionados.

Quadro 1 - Coeficiente de Mortalidade Infantil, nos municipios estudados, em 1988.

\begin{tabular}{|c|c|}
\hline Municipios & Coeficiente de Mortalidade Infantil \\
\hline 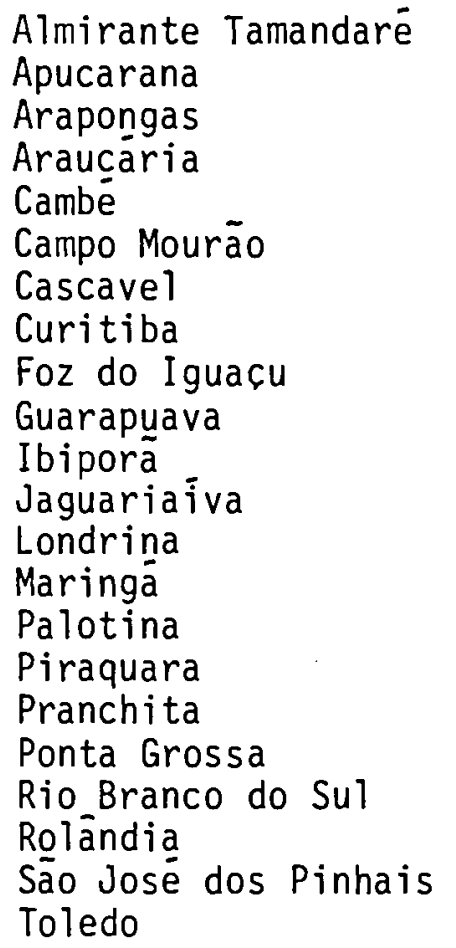 & $\begin{array}{l}62,7 \\
37,1 \\
25,9 \\
44,0 \\
28,3 \\
42,3 \\
37,7 \\
29,8 \\
26,7 \\
45,1 \\
24,0 \\
61,1 \\
26,7 \\
22,1 \\
19,4 \\
50,4 \\
4,6 \\
36,5 \\
38,1 \\
38,8 \\
37,5 \\
22,7\end{array}$ \\
\hline
\end{tabular}

Fonte: G.P.C. Fundaçāo Caetano Munhoz da Rocha. Secretaria do Estado Saúde do Paraná. 
Esses dados, apesar de indicarem que não sofreram correção quanto aos possiveis erros (como justificar, a nāo ser por erro, o coeficiente de Pranchita ser melhor que o da Suécia, 6,9/00, um dos mais baixos) mostram que 20 municīpios nāo podem ser classificados como tendo "baixa mortalidade", isto ë, coeficientes inferiores a 20 por mil nascidos vivos e 2 municipios (Almirante Tamandaré e Jaguariaiva) podem ser enquadrados como muita alta, com C.M.I. acima. de 60 por mil nascidos vivos.

A dificuldade em se encontrar dados atualizados, desagregados por municipio, dificulta caracterizar a oferta da rede pública nesses locais. 0 Instituto Brasileiro de Geografia e Estatistica, para 1988, apresenta alguns dados sobre os estabelecimentos de saúde considerados como tais, postos de saüde, centro de saúde, clīnica ou postos de assisténcia médica, pronto-socorro, unidade mista e hospital. Desses, selecionou-se alguns, abaixo indicados.

Quadro no 2 - Estabelecimentos de saūde por algumas características, segundo municipios estudados, Paraná, 1988.

\begin{tabular}{|c|c|c|c|}
\hline Municipios & $\begin{array}{l}\text { Estabelecimentos com } \\
\text { Atendimentos a pacientes } \\
\text { Externos }\end{array}$ & $\begin{array}{l}\text { Total de Lei- } \\
\text { tos para in- } \\
\text { ternacão }\end{array}$ & $\begin{array}{l}\text { No de } \\
\text { vagas }\end{array}$ \\
\hline 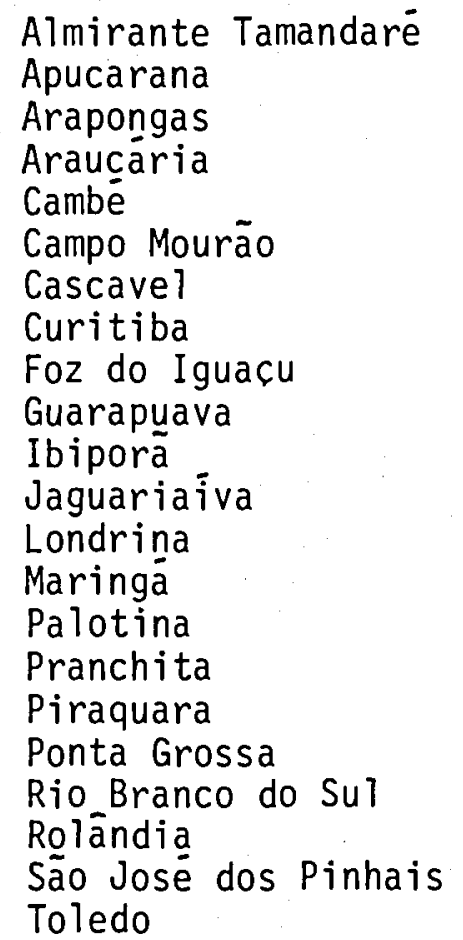 & $\begin{array}{r}10 \\
34 \\
11 \\
13 \\
13 \\
23 \\
40 \\
227 \\
15 \\
40 \\
9 \\
10 \\
83 \\
71 \\
15 \\
04 \\
15 \\
51 \\
13 \\
16 \\
19 \\
24\end{array}$ & $\begin{array}{r}72 \\
479 \\
214 \\
132 \\
125 \\
310 \\
772 \\
6715 \\
467 \\
869 \\
111 \\
192 \\
1364 \\
1377 \\
177 \\
45 \\
1420 \\
1585 \\
50 \\
290 \\
866 \\
457\end{array}$ & $\begin{array}{r}33 \\
3148 \\
1471 \\
970 \\
1124 \\
2809 \\
5150 \\
36432 \\
5654 \\
4265 \\
692 \\
859 \\
8979 \\
5523 \\
940 \\
110 \\
1028 \\
6281 \\
812 \\
939 \\
2924 \\
2378\end{array}$ \\
\hline
\end{tabular}

Fonte: IBGE. Estatīsticas da saūde. Assisténcia Médico-Sanitária. vol. 13, 1988.

Alguns municipios são cidades sede de pólos regionais como Curitiba, Londrina, Ponta Grossa, Cascavel, Maringā, apresentando um maior nümero de leitos por habitantes e de estabelecimentos externos, sendo ex- 
ceção o município de Piraquara, que concentra um grande número de leitos pela existéncia de um hospital para hansenianos e um hospital psiquiátrico, os únicos especializados mantidos pelo poder público.

0 número de nascidos vivos indica a demanda desses municípios para as atividades de atendimento à gestante e à criança na rede básica tais como imunização, puericultura e pré-natal. Se ao enfermeiro cabe supervisionar a assistência prestada, só esse grupo (com exceção do municipio de Almirante Tamandaré que apresenta um baixo número de nascimentos, talvez por registro em local da ocorréncia do parto) exigiria um número maior desses profissionais que os existentes na rede (tabela em anexo no 3) para garantir uma assistēncia de enfermagem, que inclua a supervisão desse grupo para que receba no minimo as vacinas básicas, no primeiro ano de vida e quatro atendimentos para orientaçōes de saūde para constituir-se em um adequado cuidado de saüde.

\subsection{População}

Inicialmente, à época do projeto, tentou-se obter, sem exito, em vários órgãos da categoria, o nümero e localização de enfermeiros atuando na rede municipal do Estado. Conseguiu-se posteriormente esses dados junto à Secretaria de Saúde do Estado do Paraná que, em 1986, cadastrou os recursos humanos na ärea de saúde em todos os municípios do Estado.

De acordo com os dados deste cadastro, dos 323 municipios que compōem o Estado, em 22 somente havia enfermeiros com vinculo empregatício atuando em Secretarias ou Departamentos Municipais de Saúde, em nivel local.

0 nome e o local de trabalho dos enfermeiros atuando nesses 22 municipios foram coletados a partir deste cadastro; havia 116 enfermeiros atuando nessas Secretarias ou Departamentos. Á época da coleta de dados, a composicão destes profissionais havia sofrido ligeira alteração em relação ao cadastramento da Secretaria de Estado (128 enfermeiros).

Foram excluídos aqueles enfermeiros que, à época do estudo, exerciam cargos administrativos, não atuando, portanto, nos postos. Não foram entrevistados, também, os enfermeiros que se encontravam, durante 0 período de coleta de dados, em férias ou em licença. De acordo com esses critérios, do total de 128 enfermeiros cadastrados, $117(91,4 \%)$ foram entrevistados, constituindo o universo da população estudada.

A população e a localização de cada um dos 22 municipios encontram-se no anexo, no 2, enquanto que o número de entievistados e 0 número de enfermeiros existentes na rede locai, no períocio de coleta de dados, encontram-se no anexo no 3 . 


\subsection{Procedimentos de coleta}

Pela dificuldade em se conhecer as caracteristicas tecnológicas do processo de trabaiho em 22 municipios, optou-se por utilizar formulārios com entrevistas estruturadas e semi-estruturadas.

Os formutários foram pré-testados em enfermeiros que atuavam em postos de saúde da Secretaria Estadual de Londrina e aplicados pela autora.

Os procedimentos de coleta foram feitos de duas formas distintas:

- pelo formulario (anexo no 4), que foi aplicado para os enfermeiros em nivel central sobre questões relacionados a estrutura organizacional dos servicos municipais;

- pelo formulário (anexo no 5), em que as questōes foram anotadas no momento da entrevista até à questão 20. A partir desse número foram gravadas segundo roteiro semi-estruturado (anexo no 6).

Ao entrevistado, após a explicação do tema da pesquisa e o seu objetivo, foi esclarecido que se manteria o anonimato, ressaltando-se que as questōes do formulärio no 5 seriam analisadas em relação ao município, e, sobre as gravadas, não se explicitaria o municīpio ou escola de origem, para impedir possiveis relaçōes entre entrevistados e estas duas instituições.

0 periodo de coleta correspondeu aos meses de julho de 1987 nos municipios de Rolândia, Cambé, Ibiporã; nos outros 19 municīios, de novembro de 1987 a 15 de março de 1988.

A maioria das entrevistas foi feita no local de trabalho (postos de saüde), após contato telefónico prévio para marcar data e hora e, havendo impossibilidade, durante a jornada de trabalho, no Departamento ou Secretaria de Saūde, em dias de reunião com a equipe.

As entrevistas gravadas foram transcritas pela autora e mais duas auxiliares e resultaram em 717 päginas datilografadas.

Très entrevistas tiveram questōes impossibilitadas de serem transcritas por problemas tēcnicos do gravador. Duas em Curitiba, a partir da questão no 17 e uma em Campo Mourão - questões 5, 6, 7 e 8 .

0s dados quantitativos correspondem às entrevistas gravadas e transcritas. Após leitura das mesmas os depoimentos foram classificados em grandes grupos e codificados para processamento em computador conforme anexo no 7 .

As atividades de enfermagem foram classificadas conforme proposta de SIMÕES apud MENDES ${ }^{(78)}$. "A prätica da enfermagem em seu sentido amplo: a totalidade do exercício profissional em todas as suas áreas: assisténcia, ensino, pesquisa e administração." 


\subsection{Processamento dos dados}

Apōs a anālise dos dados utilizando-se o S.A.S. (Statical Analyses Sistem) e verificando-se que a riqueza dos depoimentos ficaria anulada optou-se por incorporä-los ao trabalho.

GONCALVES $^{(56)}$, ao descrever a metodologia para estudo das caracteristicas tecnológicas do trabatho em centros de saúde que utiliza depoimentos, afirma: "As informaçōes referem-se diretamente ao processo de trabalho ou, às vezes, as suas condições de execução. Mas não são o processo de trabalho e suas condicōes de execução, porém uma descrição deles, que passa pelas representaçōes... Tomando como razoável que tais representaçōes não se constroem de modo alheio à realidade dos serviços para formar um quadro descritivo genérico dessa realidade."

Os depoimentos serão destacados em negrito e para clarificar foram cortados expressões repetitivas, vícios de linguagem.

\subsection{Variāveis}

Indicadores

Organizaçāo dos serviços

Tipo de formação do enfer meiro em enfermagem de saüde püblica em nīvel de graduação.

Caracteristicas da população quanto à sua formação

Caracteristicas dos enfer meiros quanto às condicões de trabalho

A prática dos enfermeiros

\section{Variāveis}

Existēncia de programas, atribuiçōes do enfermeiro e auxiliar de saúde, manual de normas e procedimentos, por escrito, nos municipios.

Descrição da disciplina Enfermagem de Saüde Pública quanto à ementa e, carga horäria. Avaliação da disciplina pelos entrevistados.

Distribuicãa quanto às Instituiçōes de sua graduacão, habilitação e/ou especialização em saúde. Ano da graduacãa.

Tempo de trabalho no municipio, horas contratadas de trabalho, horas dispendidas em atividades intra e extra-posto de saúde. Número de postos e atendentes sob sua supervisão.

Atividades desenvolvidas intra-posto de saüde: administrativas, assistenciais, educativas e de pesquisa. Atividades de- 
senvolvidas extra-posto de saūde em $n \bar{i}-$ vem central em programas de creches e escolas. Atividades com a comunidade. Participação na programação.

Clima Organizacional

Fatores que facilitam e dificultam 'a prātica.

\subsection{Tratamento estatístico}

Ao se definir que a população estudada seriam todos os enfermeiros atuando no periodo da coleta de dados no municipio, esta tornou-se Universo. Para a aceitação ou rejeição : da hipōtese de associação entre atividades desempenhadas e escolas, o tratamento estatistico constitui-se na aplicação do teste $Z$, ao nivel de significāncia de $5 \%$. 
IV. RESULTADO E DISCUSSĀO 


\subsection{Os Cursos de Enfermagem no Paraná}

0 Paraná tem sece cursos de enfermagem. A localização dos cursos, a carga horäria curricular e o conteúdo da disciplina enfermagem de saúde püblica serão abaixo descritos.

\subsubsection{Localizacão dos cursos}

Quadro 3. - Distribuição dos cursos de enfermagem segundo a sua sede, no Estado do Paraná, 1988.

\begin{tabular}{ll}
\hline \multicolumn{1}{c}{ Curso } & Município \\
\hline Pontifícia Universidade Católica (PUC) & Curitiba \\
Universidade Federal do Paranā & $\begin{array}{l}\text { Curitiba } \\
\text { Londrina }\end{array}$ \\
Universidade Estadual de Londrina (UEL) & \\
Centro de Estudos Superiores de Londrina & Londrina \\
(CESULON) & Maringā \\
Universidade Estadual de Maringā (UEM) & \\
Faculdade de Educação, Ciências e Letras & Cascavel \\
de Cascavel (FECIVEL) & \\
Fundação Faculdade Municipal de Educação, & Paranavā \\
Ciências e Letras &
\end{tabular}

A distribuição dos cursos mostra que os dois municipios que concentram maior nümero de habitantes, Curitiba e Londrina, ofereciam dois cursos, respectivamente.

A região Norte do Estado mantinha quatro cursos (Londrina, Maringā e Paranavaī) a sul, dois (Curitiba) e a Sudoeste, um (Cascavel).

\section{PONTIFÍCIA UNIVERSIDADE CATÓLICA DO PARANÁ}

0 mais antigo é o da Pontifícia Universidade Católica do Paraná, que incorporou a antiga Escola de Enfermagem Madre Léonie. Esta escola è a primeira do Paranà e foi fundada em 01/06/1954, tendo como entidade mantenedora a Congregação de São José, pertencente a religiosas da Provincia do Paraná.

ARNS $^{11}$, referindo-se à história de sua fundação, atirma que "o mesmo grupo de médicos pioneiros que estruturou a excelente Escola de 
Ciências Médicas, mais uma vez vislumbrou, com clareza e decisão, lado a lado com a Congregação de Irmãs de São José, a necessidade do suporte imprescindivel da enfermagem, formando contexto seguro, na ärea médico-hospitalar". Surge assim a Escola, como necessidade de médicos, professores da escola médica, ligada à Santa Casa de Curitiba e da Congregação de São Josē, responsável pela assistēncia de enfermagem, na mesma.

A primeira diretora era enfermeira e religiosa e também as suas sucessoras até dezembro de 1970.

Em 1960, foi agregada à Universidade Católica do Paranā e, em 1970, passa a ser mantida pela Sociedade Paranaense de Cultura (Irmãos Maristas). Oferecia residēncia e alimentação às suas alunas até 1972, quando muda para o Campus Universitário e sua diretoria passa a ser de enferme iras leigas.

A passagem das escolas de enfermagem, em 1962, para nivel universitärio reflete-se na Escola, que jä vinha formando poucos profissionais (de 6 à 12 egressos) e, em 1964, não se apresenta nenhum candidato ao seu vestibular, e que leva a uma campanha de divulgação no Estado. Até 1974, foi a única escola a formar enfermeiros no Paraná e ao comemorar seus 25 anos, em 1979, tinha diplomado 356 enfermeiros.

Nos seus primeiros 10 anos, (tabela em anexo no 19) período que vai de 57 a 67, formou 78 profissionais (7,4\% em 30 anos analisados). As turmas comecam a ser maiores nos 5 anos seguintes, quando forma 104 $(9,9 \%)$ e de $1973 / 83,519(49,4 \%)$ e nos 4 anos seguintes 1984 a 1987, 304 alunos $(33,1 \%)$ num total de 1.049 egressos, seguindo 0 incremento que ocorre em nivel nacional, relacionado ao ciclo expansivo 1967/73 e à reestruturação da universidade ${ }^{(15)}$.

0 curso de Enfermagem da PUC, Pr., em 1986, tinha 8 períodos: o bacharelado era de 2.865 horas e a licenciatura 3.195 horas. As disciplinas de enfermagem de Saúde Püblica estavam alocadas no sētimo período, com 30 horas teóricas e estágio supervisionado com 90 horas, e no oitavo periodo, correspondente a licenciatura, mais 15 horas, com a denominação de enfermagem de saúde pública 11.

A ementa abrangia "noçōes bāsicas no campo de saūde püblica, assim como as açōes de promoção da saúde".

0 objetivo era "preparar o aluno para atuar no campo de enfermagem de saūde pública, na promoção, proteção e recuperação da saúde, junto ao individuo, famīia e comunidade."

Em 1986, o conteúdo da disciplina Enfermagem em Saüde püblica abrangia, então, temas como saúde, saúde pública, imunizaçōes, açōes pleventivas nas doencas preventivas por imunizantes, vigiläncia epidemiológica, comunidade, atenção primária à saüde, educação em saúde, situação 
de saūide no Estado do Paranā e no Brasil, indicadores de saúde e estrutura organizacional da Secretaria Estadual de Saúde. 0 total de horas era 60, e mais de um terco, 22 horas, foi dedicada a imunizaçōes e ações preventivas nas doenças preveniveis por imunizantes.

A tabela no 19 em anexo 8 relaciona o número de egressos dessa escola. 


\section{UNIVERSIDADE ESTADUAL. DE LONDRINA (U.E.L.)}

0 curso de enfermagem iniciou-se em 1972, ainda sob o regime seriado, com 3 anos de duração e um total de 3.307 horas; a partir de 1973, entra em vigor o sistema de crédito.

No ano de 1976 a entrada passa a ser semestral; em 1982, sofre alterações, passando a 3 anos e meio ou 7 periodos.

$\bar{E}$ o ünico curso de enfermagem, no Paranā, a oferecer HabiTitação em Enfermagem em Saüde Pública, a partir de 1975 com 4 vagas. Esta habilitação sofre uma interrupção atē 1978, quando é oferecida de forma regular até dezembro de 1990, quando è extinta.

0 currīculo de 1986 totalizava 3.300 horas, com duração de 7 semestres, e a disciplina de Enfermagem de Saūde Püblica era ministrada no ültimo período, com uma carga horäria teórica de 30 horas e 90 de estágio supervisionado.

0 conteúdo da ementa da disciplina era "o papel do enfermeiro na solução dos problemas regionais de saūde e estágio em Unidades de Saúde Pública". 0 objetivo era conhecer e analisar as diferentes fases da Politica Nacional e Municipal de Saúde e conhecer e realizar as açōes de enfermagem em Assistência Primäria de Saúde. Do seu conteüdo programático constam: Enfermagem, Polïtica de Medicamentos, Reorganizaçāo do Sistema de Saüde, Financiamento.

A Habilitação em Saūde Püblica tinha carga horária de 765 horas, tendo por objetivo "propiciar a formação do profissional de enfermagem para que possa atuar nos serviços básicos de saüde e implementar as novas diretrizes em Atenção Primāria à Saúde". Os alunos desenvolviam atividades em período integral, com bolsa-trabalho e a programação dos seminários e aulas teóricas eram feitas em conjunto com os residentes.

0 nümero de egressos está relacionado na tabela no 20 em anexo no 8 . 
UNIVERSIDADE FEDERAL DO PARANÁ

0 curso de Enfermagem e Obstetrícia, do setor de Ciēncias da Saúde da Universidade Federal do Paraná, obteve autorização para sua criação e implantação em 27/05/1974. 0 primeiro vestibular è realizado em 1975, com 40 vagas em dupla entrada, sendo 24 alunos na primeira e 16 alunos na segunda turma. A primeira turma se formou em 1978 com 10 alunos.

Em 1982, o curso passou a oferecer 2 opçōes: bacharelado com 3.315 horas e licenciatura com 3.765 horas; em 1985, passa a oferecer, em dupla entrada, 25 vagas para o primeiro semestre e 25 vagas para 0 segundo semestre.

Na periodização do currículo de 1983 a 1987, a disciplina Enfermagem em Saúde Püblica e Programas de Saúde estavam no 80 período. tendo 30 horas teöricas e 135 de estāgio supervisionado.

0 plano de ensino 85/86, apresentava as seguintes unidades didäticas: Saúde Püblica e Enfermagem de Saúde Püblica; Saūde e Desenvolvimento Econōmico, Doenças Endēmicas, Sistemas de Manutenção e Recuperação de Saūde no Brasi1; Saūde da Comunidade; Atuação da Enfermagem em Unidades de Assistēncia Primāria à Saúde; Padrōes Mỉnimos da Assistēncia MaternoInfantil, Tuberculose, Saneamento, Dermatologia Sanitäria; Educação para a Saüde.

0 número de egressos consta na tabela no 21 em anexo no 08 . 
0 curso de Enfermagem e Obstetricia foi autorizado pelo decreto federal no 82.600, de 07 de Novembro de 1978. 0 currículo pleno do curso de enfermagem constava de 8 semestres, com um total de 3.675 horas, incluindo graduação e licenciatura.

A Enfermagem de Saúde Púbiica era ministrada no $6 \underline{0}$ e $7 \underline{0}$ perīodos. A Enfermagem de Saúde Pública I tinha uma carga horária total de 150 horas e a teörica, 60 horas; incluia em sua ementa temas como: prevenção primária, imunização, nutrição e saúde pública, programas de saúde. Entre os seus objetivos constava desenvolver nos alunos "conhecimento e habilidades para que seja capaz de realizar educação sanitāria na comunidade e no hospital, tornar o aluno capaz de relacionar-se persuasivamente com a comunidade, atuando como agente de mudança para a melhoria do nível de saüde".

A Enfermagem de Saúde Püblica II, com uma carga horäria de 90 horas, tinha como ementa: a organização sanitāria brasileira, processo de consulta de enfermagem, visita domiciliar, prontuärio famijlia, organização dos serviços de enfermagem, atual política de saúde brasileira. Os objetivos eram de desenvolver conhecimentos, habilidades e atitudes para dar assistēncia de enfermagem preventiva; o programa incluia temas como: a atual polïtica de saúde, açōes integradas de saúde (A.I.S.), Sistema Unificado e Descentralizaçao de Saüde (SUDS) e reforma sanitāria.

Em 1986, os alunos poderiam optar pelo estágio de Administração para desenvolvē-lo em Saúde Püblica ou na área Hospitalar. Nümero de egressos consta na tabela no 22 em anexo no 08. 
UNIVERSIDADE ESTADUAL DE MARINGĀ (U.E.M.)

0 curso de Enfermagem e Obstetricia foi criado em 09/04/1979 e implantado no segundo semestre de 1981, filiado ao Departamento de Farmácia-Bioquímica da U.E.M.

Os primeiros dois coordenadores foram profissionais não enfermeiros, e somente a sua terceira coordenadora é enfermeira, com a criacão do Departamento de Enfermagem, no segundo semestre de 1984.

0 total de carga horária do curso è de 3.030 horas (excluindo a prática desportiva): a disciplina Enfermagem em Saúde Pública era ministrada no 40 período com 90 horas teöricas e o estágio supervisionado em 60 horas. 0 conteúdo enfocava a assistência à enfermagem em saúde Pública, o atendimento nas äreas de saúde da mulher, da criança e imunizacão, com 10 horas cada unidade, destacando-se atividades de assisténcia, como exame físico, avaliação nutricional, doenças mais comuns; com 4 horas, respectivamente, saúde-trabalho, saúde mental e supervisão em Enfermagem de Saüde Pübrica.

Esta disciplina antecedia as de enfermagem obstétrica e pediātrica e, por isso, hä enfase nesta bibliografia básica da sua ementa. A ementa constava de: Metodologia de Assistēncia de Enfermagem de Saüde Püblica. Sistematização e programação da assisténcia na ārea materno-infantil, saúde do adulto e doenças transmissiveis. Atuação da enfermeira na comunidade através da famīila e de grupos organizados. Funçōes e atividades da enfermeira de saúde nos servicos de saúde, indústria, domicílio, hospitais, ambulatórios e postos de saüde.

Nümero de egressos consta na tabela no $23 \mathrm{em}$ anexo no 08. 
0 CESULON obtēm autorização para o funcionamento do seu curso em 19/03/1980. A entrada era semestral até 1985, quando passa a ser anual. O currículo (1980-1985), com carga horária de 3.450 horas, era integralizado em 7 periodos.

A disciplina Enfermagem em Saude Publica era ministrada com uma carga teórica de 30 horas e o estágio supervisionado em 90 horas no 40 periodo.

A ementa teóricà contemplava o papel do enfermeiro na solução dos problemas de saúde, organização dos serviços de enfermagem em unidades de saūde, desenvolvimento de programas de saúde pública e o atendimento de enfermagem.

0 conteūdo programātico apresentava 3 unidades: I. 0 processo de enfermagem; II. A familia; III. Principios científicos na intervenção de enfermagem de saúde püblica com a famīlia.

Neste currīculo, a Introdução à Enfermagem I, no 30 perīodo, era o primeiro contato com a área profissionalizante, tinha um conteúdo teörico de educação em saúde, política nacional de saúde, modelo de atenção primäria à saúde, política de medicamentos, em 30 horas e o estágio supervisionado, com 90 horas, em unidades de saüde da Prefeitura Municipal de Londrina, Centro de Saúde da Secretaria Estadual, visita a ambulatōrios, serviços de extensão rural e atividades educativas junto a comunidade de baixa renda.

Em 1986, um novo currículo è implantado em regime seriado com 3.390 horas, distribuidas em 4 anos; a disciplina Enfermagem de Saúde Püblica e Doenças Transmissiveis está alocada no 40 ano com 60 horas teóricas e 120 de estágio supervisionado.

0 nümero de egressos consta na tabela no $24 \mathrm{em}$ anexo no n8 
FUndACÃO FACULDADE MUNICIPAL DE EDUCACĀO, CIÊNCIAS E LETRAS DE PARANAVAI

0 curso de Enfermagem e Obstetrīicia teve autorizaçāo para o seu funcionamento em $16 / 02 / 81$ e inicia as atividades no 20 semestre letivo de 1982. 0 reconhecimento foi feito em 10/03/1987.

A duração do curso somava 3.000 horas (excluĩdas as noras/ aula de Estudos de Problemas Brasileiros e Prática Desportiva) e o tempo minimo para integralização era de 7 semestres ou 3 anos e meio.

A 1a turma formou-se em 1986 (10 semestre). A carga horária da disciplina Enfermagem de Saüde Püblica era dividida em 90 horas teöricas e 60 prāticas e ministrada no $6 \underline{0}$ período. 0 conteúdo programático compunha-se de 8 unidades; doenças infecto contagiosas; imunização; rede de frio; medidas preventivas, histōria natural das doenças; demografia; previdēncia social no Brasil; programas de saúde pública.

0 número de egressos consta na tabela no 25 em anexo no 08. 


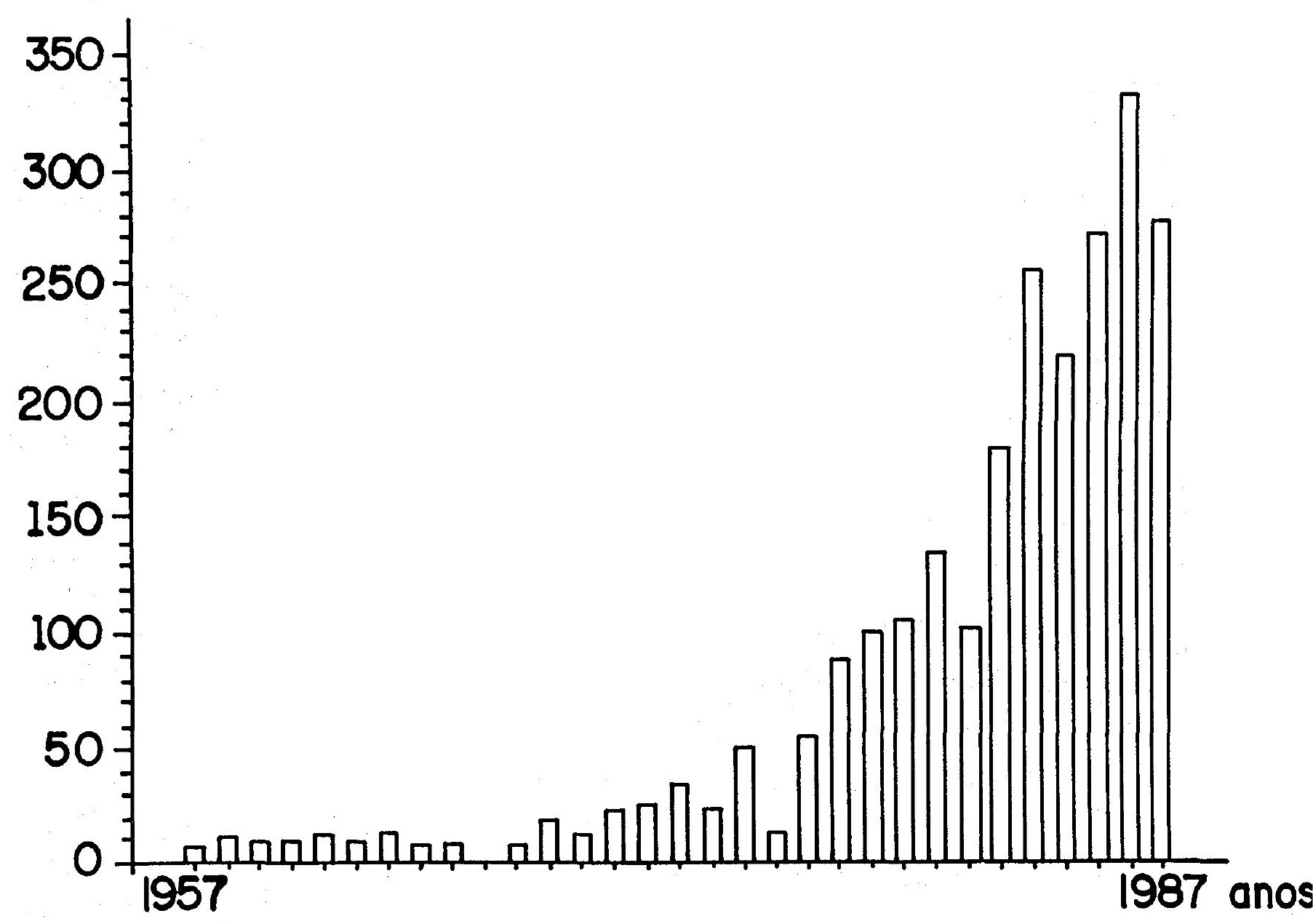

Fig. 1 - Evoluçāo do número de egressos das escolas de enfermagem do Paraná, 1957 - 1987. 
Os cursos superiores de enfermagem do Paraná formaram 2.369 enfermeiros até 1987 (tabela 17, em anexo no 1 ).

Ao se analisar a evolução de egressos, verifica-se que a partir de 1978 há um aumento crescente, com exceção do ano de 1981, quando há uma leve queda em relação aos anos anteriores. Porém, o aumento crescente se deve à criação e reconhecimento de novas escolas e não ao aumento da demanda para os cursos de enfermagem.

0 ültimo ano estudado apresenta uma diminuicão pela possīvel tendéncia à evasão, pela baixa procura dos cursos de enfermagem, fenómeno observado em outros estados do Brasil e também nos Estados Unidos, em que escassez de enfermeiros no mercado tem levado a aceitar profissionais de outros paises 65 .

\subsubsection{Anālise da disciplina Enfermagem de Saūde Püblica na grade curricular} dos cursos de Enfermagen do Paraná

Quadro 4 - Distribuição da carga horāria da disciplina Enfermagem de Saūde Püblica, segundo Escolas de Enfermagem do Paraná, 1988.

\begin{tabular}{lccc}
\hline \multirow{2}{*}{ Escolas } & \multicolumn{3}{c}{ Carga horäria } \\
\cline { 2 - 4 } & Teörica & Prätica & Total \\
\hline PUC & 30 & 90 & 120 \\
UEL & 30 & 90 & 120 \\
CESULON & 30 & 90 & 120 \\
FECIVEL & 60 & 90 & 150 \\
UEM & 90 & 60 & 150 \\
FEDERAL & 30 & 135 & 165 \\
PARANAVAİ & 90 & 60 & 150 \\
\hline
\end{tabular}

A disciplina Enfermagem de Saūde Püblica faz parte do currículo das 7 escolas de enfermagem.

No periodo estudado a carga horária constante da grade curricular variou de um minimo de 120 a 165 horas. Era ministrada em duas escolas, no início do profissionalizante e nas outras 5 , no final do curso.

As disciplinas, ministradas no inicio, tinham um conteüdo teörico programātico voltado para procedimentos técnicos, tendo em vista a necessidade dos alunos as desempenharem durante o estágio supervisionado em saúde püblica e por serem o seu primeiro contato com o cliente.

Uma única escola relaciona, eli seu programa, a consulta de enfermagem e outras duas o processo e a metodologia de assisténcia de enfermagem, respectivamente. Tais temas podem apontar uma tendéncia em con- 
siderar, nas atribuições do enfermeiro de saūde püblica, atividades próprias e específicas de sua competéncia - e a consulta de enfermagem seria uma delas. Essa concepcão tem por fundamento que o enfermeiro è um profissional independente, autōnomo e o seu objeto de trabalho ē o cuidado individualizado.

A indicação bibliogräfica do livro de LEAVELL \& CLARK - em que a saúde é vista como resultante do equilíbrio entre hospedeiro, $\quad 0$ agente e o meio - em 5 escolas e nenhum dos autores de epidemiologia social podem indicar que a saúde/doença ainda eram vistas sob o àngulo da multicausalidade e não como um processo de caráter histórico e social ${ }^{(26,}$ $73,82)$.

As políticas de saúde constituiam o conteüdo teörico de uma escola e, em outra, temas como Reforma Sanitäria, Sistema Unificado e Descentralizado de Saūde faziam parte da disciplina Enfermagem em Saüde Pública II.

Nenhuma escola contemplava temas voltados para o planejamento em saúde e programação,detectando-se pouca énfase nas atividades de administração aplicadas a saúde pública.

A pequena carga horária teörica, 30 horas em 4 escolas, impossibilita incluir uma série de conteúdos necessārios ao desempenho do profissional em serviços de saúde pública, como a variação de rotina, o controle da tuberculose e hanseniāse, o programa de atenção a saúde da criança e da mulher, educação em saüde, e participação comunitāria.

Duas escolas tinham o conteúdo teörico maior que o prático. Em uma delas a disciplina, que tinha uma carga horāria de 90 horas para 0 teōrico, era ministrada no início do profissionalizante e, como já referido. um conteúdo voltado para a área materno-infantil. A metade dos cursos incluia a comunidade como tema. Pela bibliografia constante dos programas não foi possīvel aferir qual o enfoque dado à participacão comunitária, com exceção de uma escola, em que um dos seus objetivos era "ensinar o aluno a atuar persuasivamente com a comunidade." Essa palavra pode estar 1igada às ações de convencer, induzir, em contraponto às propostas da Assisténcia Sanitāria Primária de Saúde, que è no sentido de desmonopolizacão do saber. 0 municipio, onde essa escola localiza-se, era o que tinha o eixo do seu trabalho em atividades grupais, na utilização de promotoras de saúde e até a planta física dos postos recém construīdos apresentava-se com uma estrutura diferente dos demais municipios estudados: 3 ou 4 salas para atividades de consulta médica, de enfermagem e atividades das atendentes e um grande salão para reuniões com grupos da comunidade, sob a responsabilidade da assistente social. 
4.2. A organizacão das Secretarias ou Departamentos de Saúde Municipais quanto à programaçāo, manual de normas e atribuicões da enfermagem

Tabela 1 - Distribuição quanto a presença ou ausēncia de algumas variāveis organizacionais, em 22 municipios do Estado do Paranā, 1988.

\begin{tabular}{|c|c|c|c|c|c|c|c|c|}
\hline \multirow{3}{*}{ MUNICİPIOS } & \multicolumn{4}{|c|}{ ATRIBUICÕES } & \multirow{2}{*}{\multicolumn{2}{|c|}{$\begin{array}{l}\text { PROGRAMAS } \\
\text { DE SAŨDE }\end{array}$}} & \multirow{2}{*}{\multicolumn{2}{|c|}{$\begin{array}{c}\text { MANUAL DE } \\
\text { NORMAS }\end{array}$}} \\
\hline & \multicolumn{2}{|c|}{ ENFERMEIRO } & \multicolumn{2}{|c|}{ AUXILIAR } & & & & \\
\hline & $\operatorname{sim}$ & Não & $\operatorname{sim}$ & Não & $\operatorname{sim}$ & Não & $\operatorname{sim}$ & Não \\
\hline Almirante Tamandaré & - & + & - & + & - & + & + & - \\
\hline Apucarana & + & - & - & + & + & - & + & - \\
\hline Arapongas & - & + & - & + & - & + & - & + \\
\hline Araucāria & + & - & + & - & + & - & + & - \\
\hline Cambé & + & - & + & - & + & - & + & - \\
\hline Campo Mourāo & + & - & + & - & + & - & + & - \\
\hline Cascavel & - & + & - & + & - & + & - & + \\
\hline Curitiba & + & - & + & - & + & - & + & - \\
\hline Foz do Iguaçu & + & - & + & - & - & + & - & + \\
\hline Guarapuava & - & + & - & + & - & + & - & + \\
\hline Ibiporä & + & - & + & - & + & - & + & - \\
\hline Jaguariaiva & - & + & - & + & - & + & - & + \\
\hline Londrina & + & - & + & - & + & - & + & - \\
\hline Maringā & - & + & - & + & + & - & + & - \\
\hline Palotina & + & - & + & - & - & + & - & + \\
\hline Piraquara & - & + & - & + & - & + & - & + \\
\hline Ponta Grossa & - & + & - & + & - & + & - & + \\
\hline Pranchita & - & + & - & + & - & + & - & + \\
\hline Rio Branco do Sul & - & + & - & + & - & + & - & + \\
\hline Rolândia & + & - & - & + & + & - & + & - \\
\hline São José dos Pinhais & + & - & - & + & - & + & - & + \\
\hline Toledo & - & + & - & + & - & + & - & + \\
\hline TOTAL & 11 & 11 & 08 & 14 & 09 & 13 & 10 & 12 \\
\hline
\end{tabular}

Menos de $1 / 3$ dos municipios estudados tinham presentes as variāveis pesquisadas e, destes, 5 situam-se na região norte do Paraná (Cambé, Ibiporã, Campo Mourão, Londrina e Rolândia) pioneiras na implantação de serviços municipais de Saūde e na prātica de assistēncia primária, bem como Curitiba,e estes foram classificados corio organizados.

$\mathrm{Na}$ metiade dos Municipios foram relacionadas as atribuiçōes dos enfermeiros. Quase $40,0 \%$ não dispunham de documentos escritós com as 
atribuicōes dos Auxiliares de Saúde; porcentagem um pouco mais alta $(45,4 \%)$ relata a existéncia de manual de normas, procedimentos e rotinas elaborados próprios para consulta nos Postos de Saúde. Ao adicionar-se os manuais, editados pela Secretaria de Saúde e Bem Estar Social do Paraná, utilizados por alguns Municípios (Arapongas, Rio Branco do Sul e São José dos Pinhais) o percentual é um pouco mais alto $(59,1 \%)$, mas ainda baixo, se considerar que são poucos os municipios que possuiam enfermeiro, supervisionando diariamente os auxiliares de saúde, como Cambé, Araucäria, Cas cavel e Curitiba e não de forma eventual como nos outros.

A utilização de normas tem sofrido críticas por levar a um mecanicismo no atendimento ao cliente ou à burocratizacão no sentido negativo da palavra (esquecem-se os fins em função dos meios), porém o trabalho coletivo necessita ser organizado de forma racional ${ }^{56}$.

Os programas de saúde foram referidos em $40,9 \%$ dos municípios. Nesse trabalho não foi considerado se estes programas

utilizavam alguma técnica de planejamento, e/ou programação em saúde para o levantamento das necessidades sociais da população, tendo por base dados epidemiolögicos como o proposto pela CENDES/OPS ${ }^{2}$.

A prática de planificação em saūde no Brasil tem a Fundacão SESP, como uma das pioneiras, programando algumas atividades de saüde, antes mesmo da formulação do método CENDES-OPAS, que è elaborado em 1965 e está baseado na idéia de eficiencia na utilização de recursos, custo-benefício e no privilegiamento da programação local.

Um dos prōprios autores dessa técnica, TESTA, ao fazer a revisão crítica da utilização desse método e em sua proposta apud RIVERA 105 incorpora elementos do modelo CENDES/OPAS no seu diagnóstico administrativo, tais como: análise dos recursos, acesso populacional aos servicos, estrutura da população e das doenças.

Apesar das crīticas ao planejamento normativo, em não considerar a viabilidade politica e a existéncia de atores sociais que aderem ou podem oferecer resisténcia a uma decisão tecnocrātica em saúde, não se pode ainda dispensar elementos do seu diagnóstico. Se esse modelo estivesse sendo utilizado nos serviços de saüde municipais, teriamos uma prática dos profissionais com pelo menos uma visão dos grupos prioritários a serem atendidos e avaliação da sua ação.

SHRAIBER ${ }^{111}$ considera a técnica de programação local um referencial para açōes de planejamento ascendente para a formulação de um plano de alcance nacional.

A ausēncia de programação pressupõe que, mesmo de forma rudimentar, configuram-se dois modelus assistenciais, denominados pela autora acima citada, um de "consultação" e o outro de controle, sobre 
a doença/saüde.

No primeiro caso, seria a produção de assistência mëdica individual, feita pelos médicos clínicos e os demais trabalhadores organizando-se em função dessa forma de assisténcia; no segundo, o trabalho sanitário de proteção e promoção de saūde, poderá, em alguns programas, envolver ações de diagnóstico e tratamento ${ }^{111}$.

\subsection{Características da populacão estudada}

\subsubsection{Escolas de Graduação}

TABELA 2 - Número e porcentagem dos enfermeiros em postos de saúde municipais, segundo as escolas de graduação, Paraná, 1988.

\begin{tabular}{lcc}
\hline \hline ESCOLA & № & $\%$ \\
\hline Pontifícia Universidade Catölica & 37 & 31,6 \\
Universidade Estadual de Londrina & 26 & 22,2 \\
Universidade Federal do Paranā & 16 & 13,7 \\
FECIVEL & 16 & 13,7 \\
CESULON & 8 & 6,8 \\
Universidade Estadual de Maringā & 4 & 3,4 \\
Outras* & 10 & 8,6 \\
\hline T O T A L & 117 & 100,0 \\
\hline
\end{tabular}

Outras: * Santa Maria, USP Ribeirão Preto, Federal do Rio de Janeiro, Presidente Prudente, Caxias do Sul, Concördia, Pelotas, Tubarão, Munich, Dom Doménico, (todas com frequência um).

0 maior nümero de graduados era da Pontificia Universidade Católica do Paraná, que,somados aos da Universidade Federal do Paraná, perfaziam $45,3 \%$. Esse fato pode ser explicado pelo grande número de entrevistados alocados nos serviços de saúde do municipio de Curitiba e região metropolitana.

A mesma anālise pode ser feita em relação à Universidade Estadual de Londrina e aos municīpios da região norte do Paraná.

Os enfermeiros, formados em outras escolas, aparecem com baixa frequéncia $(8,6 \%)$ e foi grande a diversidade das faculdades de origem. 
4.3.2. Ano da graduação

TABELA 3 - Número e porcentagem dos enfermeiros em postos municipais segundo ano da graduação, Paraná, 1988.

\begin{tabular}{|c|c|c|}
\hline ANO DE GRADUACC̃O & No & $\%$ \\
\hline Antes de 1975 & 02 & 1,7 \\
\hline $75|-| 76$ & 01 & 0,9 \\
\hline $77 \mid \longrightarrow 78$ & 08 & 6,9 \\
\hline $79|-| 80$ & 09 & 7,7 \\
\hline $81|-|-82$ & 20 & 17,1 \\
\hline $83|-|$ & 35 & 29,9 \\
\hline $85|-|-\mid 86$ & 42 & 35,8 \\
\hline TOTAL & 117 & 100,0 \\
\hline
\end{tabular}

A maior parte dos enfermeiros $(65,8 \%)$ formou-se há menos de 5 anos e, destes, $35,8 \%$ nos anos de 1985/86, o que demonstra uma parcela bastante expressiva de recém graduados e, em conseqléncia, com pouco tempo de experiência profissional.

\subsubsection{Habilitados en Enfermagem de Saúde Pública segundo Instituiçōes de} Ensino

TABELA 4 - Nümero e porcentagem dos enfermeiros em postos municipais segundo cursos de habilitação em saúde pública, Paraná, 1988.

\begin{tabular}{llr}
\hline \hline INSTITUICÕES DE ENSINO & № & $\%$ \\
\hline Universidade Estadual de Londrina & 12 & 63,1 \\
Pontifícia Universidade Catōi ica/Sorocaba & 03 & 15,7 \\
Universidade Estadual do Rio de Janeiro & 01 & 5,3 \\
Presidente Prudente & 01 & 5,3 \\
E.E. Ribeirão Preto/USP & 01 & 5,3 \\
Escola Paulista de Enfermagem & 01 & 5,3 \\
\hline TO T A L & 19 & 100,0 \\
\hline \hline
\end{tabular}

É baixo o percentual dos que possuen formação especīica na ärea,comparando-se com a Règião Sul corio um todo, eri que o percentual foi de $55,9 \%$ com curso de Habilitação em 1983 (23).

A Habilitação em Saúde Pública foi cursada por $16,2 \%$ dos 
enfermeiros. 0 municipio de Londrina contava em seus quadros com 8 habilitados $(15,3 \%)$ e o município de Cambé tinha $80 \%$ dos pesquisados com este curso, seguidos de Maringá com $75,0 \%$, Londrina $(53,3 \%)$ e Ibiporã $(50,0 \%)$, todos estes na região Norte do Paranā, justificado pela absorcão de profis sionais, oriundos da Universidade Estadual de Londrina, única faculdade.no Paranä a oferecer Habilitação em Saúde Püblica.

Habilitaram-se nos anos de 1984, 1985 e 1986, 15 enfermejros, 5 em cada ano, o que representa $78,9 \%$ dos habilitados.

\subsubsection{Especializados en Saúde Pública segundo Instituiçōes de Ensino}

TABELA 5 - Nümero e porcentagem dos enfermeiros em postos municipais segundo cursos de especialização em Saúde Pública, Paraná, 1988.

\begin{tabular}{llc}
\hline \hline ESCOLA & No & $\%$ \\
\hline Universidade de Ribeirão Preto & 14 & 45,2 \\
Fundação Oswaldo Cruz & 07 & 22,6 \\
Pontifícia Universidade Catōlica do Paranā & 06 & 19,4 \\
Secretaria Estadual de Saúde do Paraná & 02 & 6,4 \\
Faculdade de Saúde Püblica/USP & 01 & 3,2 \\
Faculdade Evangélica do Paraná & 01 & 3,2 \\
\hline T O T A L & 31 & 100,0 \\
\hline \hline
\end{tabular}

A proporção de enfermeiros com especialização foi de $28,0 \%$ em relação ao total e é proporcionalmente maior, quando comparado com a $\mathrm{Ha}-$ bilitação em Saúde Pública $(16,3 \%)$, em razão da oferta superior de vagas desses cursos. Mas assim mesmo é baixo o nümero de especialistas, levandose em consideração a pequena carga horária em Saúde Pública, oferecida nos cursos de graduacão.

Dez municīios não tinham em sua rede, em nível local, nenhum profissional com habilitação ou especialização: Almirante Tamandarē, Arapongas, Cascave1, Guarapuava, Jaguariaiva, Palotina, Piraquara, São Josē dos Pinhais, Toledo, Ponta Grossa, (esta ültima, no momento da pesquisa, oferecia, em convēnio com a FIOCRUZ, curso de especialização para enfermeiros e médicos de seus postos de saúde).

A UNAERP foi a escola que mais formou especialistas, por ser a instituição que tem oferecido este curso em Curiliba e Londrina, com regularidade em relação à Universidade Católica do Paraná, que ministrou um curso e a FIOCRUZ, que, em convênio com a Secretaria de Saúde Bem Estar So- 
cial do Paranā, realizou dois cursos em Londrina e três em Curitiba.

Outro fator, a ser considerado na formação desses especialistas, è a forma com que os cursos da UNAERP são ministrados, em finais de semana, favorecendo a frequéncia dos que estão trabalhando, mas ao mesmo tempo podendo levar a uma baixa qualidade de ensino, pela falta de prática e concentrada carga horária.

As Universidades paranaenses, tanto as Estaduais e a Federal, deveriam proporcionar cursos de especialização para estes profissionais, em convênio com as Secretarias ou Departamentos municipais de saúde, como ocorria desde 1970 na Faculdade de Saüde Püblica da Universidade de São Paulo e Secretaria Estadual de Saüde ${ }^{129}$.

Uma das entrevistadas informou que especializou-se em curso ministrado na Faculdade Evangélịca de Londrina, mas não se obteve maiores dados sobre este curso.

No Brasil, em 1983, nos estabelecimentos não hospitalares, $41,9 \%$ dos enfermeiros contavam com o curso de especialização em Saúde Püblica e na Região Sul 24,6\% (36). Os percentuais desse estudo são superiores aos da Região Sul em 1983, mas inferiores ao do Brasil na mesma época.

\subsubsection{Tempo de trabalho nos municīpios estudados}

TABELA 6 - Nümero e porcentagem dos enfermeiros em postos de saüde municipais segundo tempo de trabaiho, Paraná, 1988.

\begin{tabular}{|c|c|c|c|}
\hline \multicolumn{2}{|c|}{$\begin{array}{c}\text { TEMPO DE TRABALHO } \\
\text { (ANOS) }\end{array}$} & \multicolumn{2}{|c|}{ ENFERMEIRO } \\
\hline 01 & 1 & 30 & 25,6 \\
\hline 11 & 2 & 39 & 33,3 \\
\hline 21 & 3 & 28 & 24,7 \\
\hline 31 & 4 & 07 & 5,9 \\
\hline 41 & 5 & 09 & 7,6 \\
\hline $51-$ & 6 & 01 & 0,8 \\
\hline 6.1 & 7 & 01 & 0,8 \\
\hline 71 & 8 & 01 & 0,8 \\
\hline 8 e mais & & 01 & 0,8 \\
\hline$T O T A L$ & & 117 & 100,0 \\
\hline
\end{tabular}

Mais da metade dos prófissionais estava aiuando há menos de 2 anos na rede municipal, fato que pode estar associado ä expansão dos servicos municipais a partir da assinatura do convénio de Assistencia In- 
tegrada de Saude (AIS), em setembro de 1986, no Estado do Paraná.

Os municīpios de Araucāria, Cambē, Curitiba, Londrina e Toledo apresentavam 13 enfermeiros com mais de 4 anos de trabalho nos postos de saúde, o que corresponde a $11,1 \%$ dos entrevistados, mas tratavase de servicos municipais organizados há mais tempo.

Esses percentuais diferem do tempo de servico dos enfermeiros no Departamento Regional de Saúde - DRS6 - Ribeirão Preto, estudados por STEAGALL - GOMES ${ }^{121}$, que encontrou com menos de 5 anos $48,6 \%$ e com mais de 10 anos $22,8 \%$ e do estudo COFEN/ABEN ${ }^{36}$, em que $32,7 \%$ dos enfermeiros lotados em nivel central, em Secretarias Municipais, tinham $32,7 \%$ com 10 anos e 10,2\% com menos de 1 ano.

Os recém graduados eram muitas vezes os primeiros enfermeiros no servico, iniciando o seu trabalho sem ter à sua disposição enfermeiros experientes, que poderiam atenuar o chamado choque da realidade no seu periodo de socialização no trabalho.

\subsubsection{Carga horäria contratual}

TABELA 7 - Nümero e porcentagem de enfermeiros em postos de saúde municipais segundo horas de trabalho contratadas por semana, Paraná, 1988.

\begin{tabular}{ccr}
\hline \hline HORAS SEMANAIS CONTRATADAS & № & $\%$ \\
\hline 18 & 01 & 0,8 \\
20 & 03 & 2,6 \\
24 & 01 & 0,8 \\
30 & 47 & 40,2 \\
35 & 06 & 5,1 \\
40 & 56 & 47,9 \\
48 & 03 & 2,6 \\
\hline T O T A L & 117 & 100,0 \\
\hline \hline
\end{tabular}

A maioria dos enfermeiros faziam uma jornada de 40 horas semanais, seguida pela de 30 horas. 0 municipio de Curitiba tinha uma jornada de 30 horas para os enfermeiros, mas aos que exerciam função de chefia era oferecida a possibilidade de 10 horas-extras, perfazendo um total de 40 horas.

Pode-se questionar se uma jornada de 30 horas o: de saúde, com 2 turnos de trabalho em sua majoria ou em 3 turnos e uma rede com grande proporcão de pessoal auxiliar, necessitando de supervisão cons- 
tante e com múltiplas atividades, è a melhor para o enfermeiro de saüde püblica recém-formado.

Embora a redução de jornada de trabalho seja uma conquista da classe trabalhadora, o Conselho Federal de Enfermagem e Associação Brasileira de Enfermagem consideram a carga horäria semanal de 40 horas excessiva para as categorias de enfermagem em estabelecimentos de saúde. No entanto a Comissão de Recursos Humanos da 8a Conferência Nacional de Saúde recomendava também a jornada de 40 horas semanais.

Os municipios, que contavam com enfermeiros em regime de trabalho de 40 horas semanais contratadas, eram Almirante Tamandaré, Apucarana, Campo Mourāo, Ibiporā, Jaguariaīva, Cascavel, Guarapuava, Palotina, Ponta Grossa, Pranchita, Rio Branco do Sul, Rolāndia e Londrina. Nesse último, duas, a pedido, reduziram a carga horäria para vinte horas.

o Posto de Saúde como um ambulatório hospitalar não se apre senta como um trabalho sobre pressão, características de um pronto socorro ou de uma unidade de terapia intensiva, onde as decisões sobre vida/morte são freqlentes, os pacientes são graves e portanto menos desgastante sob esse ponto de vista ${ }^{70}$. 0 maior tempo de permanéncia no trabalho e um único vinculo empregaticio possibilitam um maior envolvimento com as propostas de trabalho da instituição. Se isso não acontece è porque as politicas sociais vigentes nāo favorecem a uma remuneração dos profissionais, que permitam essa escolha. 


\subsubsection{Horas de trabalho intra e extra Postos de Saúde}

TABELA 8 - Número e porcentagem de horas de trabalho intra e extra-posto de saüde dos enfermeiros em postos de saúde municipais, Paraná, 1988.

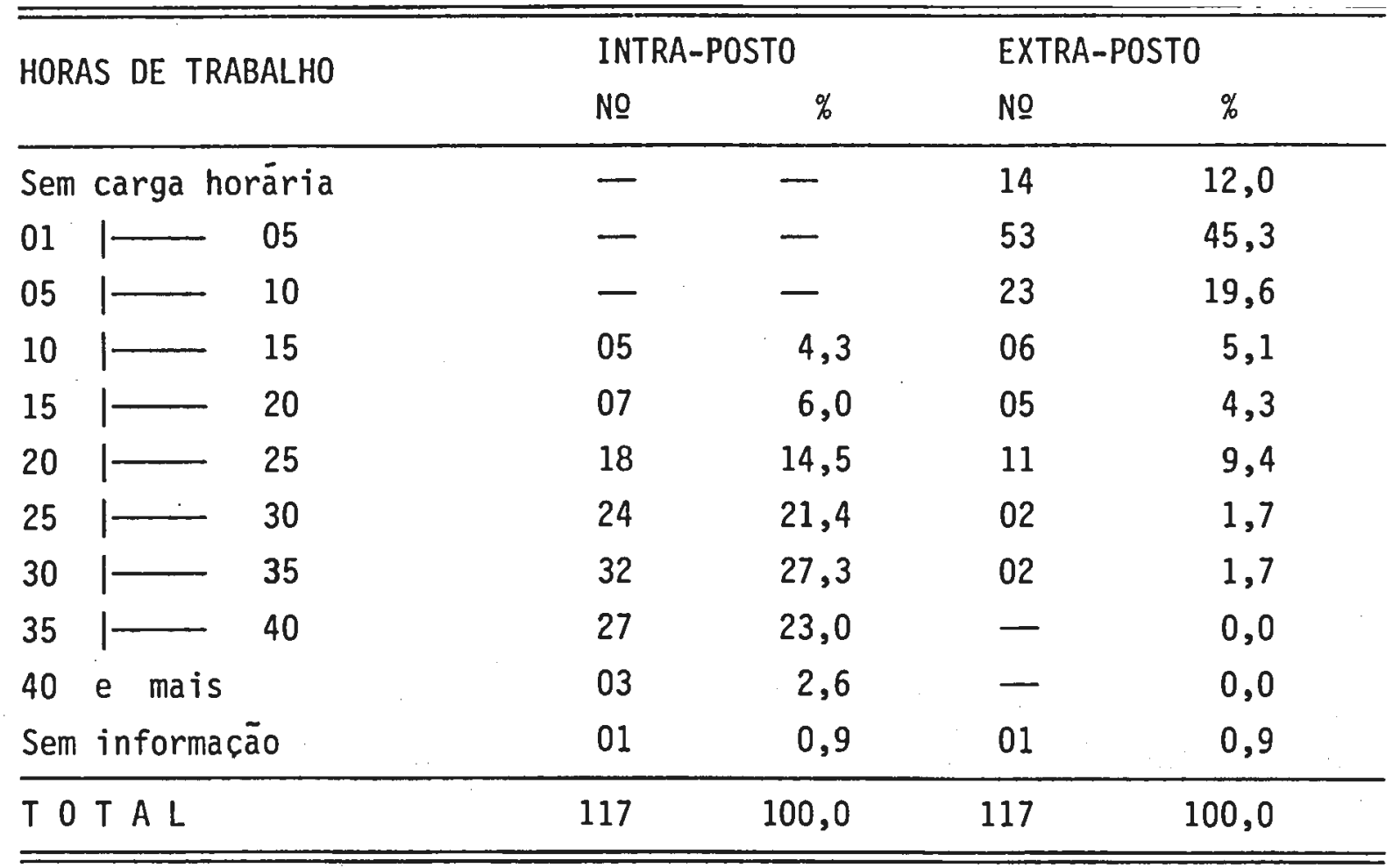

As horas extras consideradas foram as dispendidas em atividades, que exigiam o deslocamento do enfermeiro para outro local. A maioria eram atividades não ligadas a programas desenvolvidos pelo Posto de Saúde, com exceção do municỉpio de Curitiba, em que foram computadas horas dedicadas ao trabalho em creches e escolas, constantes dos programas da Secretaria. Nesse municipio, as reuniōes em nivel central eram realizadas de forma rotineira com as chefias do P.S. e 21 enfermeiros dispunham de 4 horas para essa atividade.

Do total de entrevistados, $14(12,0 \%)$ declararam não ter horas de trabalho fora do posto de saüde. Tinham menos de 5 horas por semana de atividades fora do Posto de Saúde 45,3\%. Estas horas são necessārias, considerando que deve existir, com certa periodicidade, reuniōes da equipe em nīvel central para discussōes, normatização, reciclagens, pois a rede é dispersa, não concentrando em um único local os profissionais.

0s que dispendiam mais de 10 horas estavam deslocados para atividades em nivel central, como por exemplo, nos municipios de Apucarana e Rolāndia, em que as atividades de coordenação eram de todos os prófissio nais entrevistados, ou em outros como Londrina, onde os enfermeiros estavam participando de treinamento de auxiliares de saüde ou de comissões para 
normatização de rotinas.

\subsubsection{Rełaçāo numérica Atendentes/Enfermeiros}

TABELA 9 - Relação numérica de enfermeiros por atendentes segundo municịpios e média de atendentes por enfermeiro, Paraná, 1988.

\begin{tabular}{|c|c|c|c|c|}
\hline MUNICİPIO & $\begin{array}{l}\text { ENFERME IRO } \\
\text { NO }\end{array}$ & $\begin{array}{r}A \top \\
\text { RURAL }\end{array}$ & $\begin{array}{l}\text { ENTE } \\
\text { URBANO }\end{array}$ & $\begin{array}{l}\text { MÉDIA POR } \\
\text { ENFERMEIRO }\end{array}$ \\
\hline Almirante Tamandaré & 02 & 09 & 10 & 9,5 \\
\hline Apucarana & 03 & 04 & 14 & 6 \\
\hline Arapongas & 02 & 01 & 06 & 3,5 \\
\hline Araucāria & 06 & 10 & 22 & $\dot{5}, 3$ \\
\hline Cambē & 05 & 一 & 31 & 6,2 \\
\hline Campo Mourão & 03 & 07 & 12 & 6,3 \\
\hline Cascavel & 11 & 01 & 10 & 1 \\
\hline Curitiba & 41 & - & 522 & 12,7 \\
\hline Foz do Iguaçu & 03 & - & 25 & 8,3 \\
\hline Guarapuava & 02 & 12 & 29 & 20,5 \\
\hline Ibiporã & 02 & 02 & 11 & 6,5 \\
\hline Jaguariaiva & 01 & 04. & 04 & 8 \\
\hline Londrina & 15 & 17 & 62 & 5,2 \\
\hline Maringā & 04 & 01 & 26 & 9,2 \\
\hline Palotina & 02 & 05 & 07 & 6 \\
\hline Piraquara & 01 & 09 & 03 & 12 \\
\hline Ponta Grossa & 04 & 06 & 24 & 7,5 \\
\hline Pranchita & 01 & 02 & 04 & 6 \\
\hline Rio Branco do Sul & 01 & 16 & 07 & 23 \\
\hline Rolāndia & 03 & 04 & 06 & 3,3 \\
\hline São Josē dos Pinhais & 01 & 07 & 07 & 14 \\
\hline Toledo & 04 & 14 & 11 & 6,2 \\
\hline$T O T A L$ & 117 & 131 & 853 & 8,4 \\
\hline
\end{tabular}

A média de auxiliares de saüde por enfermeiro apresentou grande variabilidade de município para municīpio. Isto está condicionado à estrutura organizacional dos postos de saúde, em que municipios como Curitiba, tinham em cada posto, 1 enfermeiro e 14 auxiliares de saúde e Cascavel em que esta relação enfermeiro/atendente era 1 por 1 .

0 número de atendentes e a relação pur enfermeiro apresentou valores pröximos aos encontrados pelo estudo COFEN/ABEN ${ }^{29}$ em que $85,2 \%$ 
da forca de trabalho nos postos de saúde correspondiam a atendentes e a relação enfermeiro/atendente em Centros de Saüde era de $8,2 \%$, os achados desse estudo foram $88,1 \%$ e 8,4 , respectivamente.

Os municípios apresentaram grande variabilidade na relação numérica enfermeiro/atendentes (inclui auxiliares de saúde, agentes de saüde, diferentes nomes, mas todos com treinamento de 3 meses e muitas vezes menos ainda).

A proporcão foi maior na capital, Curitiba, onde a rede de postos oferecia consultas nas especialidades bäsicas (clínica, pediatria e ginecologia) e atividades como atendimentos a creches e escolas da ärea programātica em 3 turnos de atendimento, exigindo maior nümero de atendentes para o apoio dessas atividades.

A carga horária contratual, no periodo estudado, era de 30 horas e o nümero de atendentes por turno em média era de 3 , variando em função do nümero de médicos no posto.

Num outro extremo, o municipio de Cascavel apresentava uma relação: enfermeiro/atendente de $1: 1$, mesmo em postos de zona urbana. (Comumente, os postos de zona rural não tem médico ou enfermeira permanentes e tem só um auxiliar de saúde, não justificando, pelo número de habitantes, uma equipe com mais profissionais ou ocupacionais.)

Um agravante dessa relaçăo era a rígida divisão de atividades entre o enfermeiro e o atendente. Isso impossibilitava, no caso 'de falta de qualquer dos elementos, a continuidade do trabalho e mesmo o mecanismo de deslocamento de um. profissional para as substituições em faltas ou férias.

A municipalização desloca para o poder local a decisão de implantar o seu modelo assistencial e a provisão dos recursos necessärios para a sua implementação. A ausēncia de programação, em muitos municīpios estudados, indica que a alocação de recursos não estava baseada em parāmetros, sejam eles da oferta ou da demanda. 
4.3.9. Postos de Saúde sob supervisāo do enfermeiro

TABELA 10 - Relação numérica dos enfermeiros segundo municípios e postos de saüde sob sua supervisão, Paranā, 1988.

\begin{tabular}{|c|c|c|c|}
\hline MUNICÍPIOS & $\begin{array}{l}\text { POSTOS } \\
\text { NO }\end{array}$ & $\begin{array}{c}\text { ENFERMEIROS } \\
\%\end{array}$ & MÉDIA \\
\hline Almirante Tamandaré & 07 & 02 & 3,5 \\
\hline Apucarana & 10 & 03 & 3,3 \\
\hline Arapongas & 03 & 02 & 1,5 \\
\hline Araucāria & 08 & 06 & 1,3 \\
\hline Cambé & 07. & 05 & 1,4 \\
\hline Campo Mouräo & 12 & 03 & 4 \\
\hline Cascavel & 11 & 11 & 1 \\
\hline Curitiba & 41 & 41 & 1 \\
\hline Foz do Iguacu & 09 & 03 & 3 \\
\hline Guarapuava & 24 & 02 & 12 \\
\hline Ibiporã & 05 & 02 & 2,5 \\
\hline Jaguariaiva & 05 & 01 & 5 \\
\hline Londrina & 29 & 15 & 1,9 \\
\hline Maringā & 09 & 04 & 2,2 \\
\hline Palotina & 10 & 02 & 2,5 \\
\hline Piraquara & 04 & 01 & 4 \\
\hline Ponta Grossa & 20 & 04 & 5 \\
\hline Pranchita & 03 & 01 & 3 \\
\hline Rio Branco do Sul & 09 & 01 & 9 \\
\hline Rolāndia & 06 & 03 & 2 \\
\hline São José dos Pinhais & 11 & 01 & 11 \\
\hline Toledo & 17 & 04 & 4,2 \\
\hline$T O T A L$ & 260 & 117 & 2,1 \\
\hline
\end{tabular}

Os 117 enfermeiros supervisionavam 171 postos na zona urbana e 89 na zona rural; com excecão dos municīpios de Curitiba e Cascavel, que tinham 1 enfermeiro por posto de saüde, os outros não alcancavam esta média. Guarapuava e São José dos Pinhais tinham uma média de 12 e 11 postos para cada enfermeiro, respectivamente.

0 grande número de postos sob a supervisão do enfermeiro levava a presença do profissional somente parcialmente no local de trabaino, dificultando o processo de supervisão dos auxiliares de saúde e o desenvolvimento de outras atividades. 
4.4. A prática dos enfermeiros

\subsubsection{Atividades Administrativas}

QUADRO 5 - Nümero e porcentagem de atividades administrativas intra-posto de saúde relacionadas pelos enfermeiros em municipios do Paranā, 1988.

ATIVIDADES

NO

$\%$

Supervisão de auxiliares de saúde

90

76,1

Organização do serviço

47,0

Coordenação de programas

31,6

Elaboração de relatórios/Escalas

44

39,1

Direção de Postos de Saüde

30

25,6

Reuniōes com equipe

7

6,0

\subsubsection{Supervisão}

A supervisão foi a atividade administrativa mais referida pe los enfermeiros. Apresentou-se com diferentes caracteristicas, tendo em vista a estrutura organizacional heterogénea dos municípios, em relação ao nümero de postos por enfermeiros e o número de auxiliares de saúde sob sua supervisão analisados nas tabelas 9 e 10.

Os depoimentos permitem visualizar que havia 6 diferentes maneiras de desempenhar a atividade:

a) Supervisão Educativa.

"dentro da supervisão a gente faz educacão continuada, temos reuniões semanais onde, na medida do possīvel, quando hā dificuldade no assunto... então a gente vai e discute alguma coisa, mas assim ben esporädica."

b) Supervisão prestando atendimento .

"vou na zona rural, quero fazer pós (consulta) porque eu quero ler a pré. Não quero ficar em cima do paciente questionando: ver a pré, ver se bate com o diagnóstico, conferir a pós-consulta, é uma reciclagem constante."

"Acompanho o trabalho desenvolvendo tarefas junto com os próprios agentes de saúde." 
c) Supervisão fiscalizadora.

"A supervisão no meu entender, a supervisāo é isso: é a gente checar se estā visto geladeira... é ver se eles estão orientando direitinho."

d) Supervisão indireta e por Telefone.

"Não existe supervisāo direta à noite, a gente faz indiretamente. Por trabalhar no perīodo de dia no posto vocé acaba sendo responsāvel por esse periodo. Então automaticamente no dia seguinte vocé chega e "oh, como é que foi no dia anterior? quais os tipos de problemas?" Vocé acaba olhando os relatórios, as anotaçōes dos diagnósticos, assim para ter uma idéia de cono foi a demanda. Volta e meia o que aconteceu, ele (o auxiliar) liga para minha casa: olha, diz aī, o que eu faço? E assim vocé acaba indiretamente fazendo supervisāo."

e) Supervisão à distãncia.

"É uma supervisão à distāncia realmente. Por exemplo, não temos dias fixos para ir lā. Varia muito pelas circunstāncias en que me encontro aqui e pelas circnstāncias de recursos para me locomover daqui... Entāo a gente passa por lá, quer saber as queixas, o que está faltando. Fora isso, a menina de lā... A gente tem um sistema: se ela precisa alguma coisa ou. que eu precise ir lá prá resolver alguma situaçāo, ela manda bilhetinho e a gente vai. Mas para isso, a gente passa por lá uma ou duas vezes por semana, tem semana que a gente passa sem ver."

f) Supervisão Verbal.

"Mas a supervisão mesmo é verbal e quando eu chego lá, tem dias que eu fico a manhã toda em um posto ou só 10, 20 minutos em cada posto.

0 que está faltando ou o que aconteceu de anormal? pra regularizar. (sü pervisora de 7 postos, 1 ano de formada e 4 meses de trabalho no município)."

As justificativas, para que a função não estivesse sendo desempenhada entre os entrevistados, foram:

a) Demanda excessiva por falta de recursos humanos e/ou acúmulo de atividades.

"É meio utópico esse termo viu, porque quando vocé acaba indo para o posto, vocē acaba tocando o serviço."

"... quando falta um funcionário, aī venho, tomo o lugar do funcionārio, faço o serviço."

b) Carga Horāria Insuficiente para supervisão.

"A gente tem 4 horas para cada posto, entāo a gente accmpanha assil: de leve, porque realmente nāo tem condiçōes." 
As criticas de enfermeiros, que tinham mais de um posto para supervisionar, levaram os profissionais a.dar algumas denominaçoes: dan do um novo significado ao termo (supervisāo.sem suas rajizes no latim, onde significa olhar por cima).

"Nōs estamos dando atē um apelido: nāo é super-visāo, ē micro-visāo."

Uma das entrevistadas fora da entrevista a denominou de supervisão "beija-flor", isto $\bar{e}$, que se assemelha a ave que passa rapidamente de flor em flor.

Em um municipio com um grande número de postos e enfermeiros em pequeno número, duas entrevistadas depoem:

"A função, que eu fui contratada desde o inīcio, é a supervisão. Supervisão nestes cinco postos de saúde! Eu, no inīcio, particularmente briguei, briguei comigo mesmo. Eu nāo vejo no trabalho de enfermagem, eu não vejo que me gratifique pessoalmente fazendo supervisão: ficando de posto em posto, levando vacina para um, vendo o que estā errado no outro, apagando incêndio aqui, consertando outro aī."

"A supervisão não é vocé ir lá e dar uma chegadinha. Acho que fica uma coisa fora da realidade daquele posto. De repente, vocé vai lá uma vez por semana e quer supervisionar o Posto."

Os recursos humanos escassos, em relação ao nümero de postos, auxiliares de saúde e enfermeiros, a distância e as dificuldades de transporte levam ao estabelecimento de mecanismos que compensam a auséncia de supervisor como "supervisāo indireta", "à distāncia" e por "telefone" (nesse ültimo caso, quando os postos dispõem de telefone).

A supervisão no sentido mais amplo ocorre, quando existe um acompanhamento do trabalho de um superior sobre. o trabalho de um subordinado.

Para CHIAVEnATO 31,32 esta se enquadra na "funçāo de direção que ocorre no nỉvel operacional, em que são os ünicos administradores que dirigem atividades de pessoas nāo administrativas, que executam tarefas especializadas ou fragmentadas" e os considera administradores de primeira linha, responsável pelas operações diārias e imediatas.

0 enfermeiro pode ser considerado um supervisor de primeira linha, na medida em que, dentro da instituição hospitalar ou de saúde pública, tem sob sua responsabilidade ocupacionais (atendentes ou auxiliares de saúde) que executam tarefas fragmentadas.

0 supervisor de primeira linha, segundo este autor, apresenta as seguintes caracteristicas, que podem ser aplicadas aos enfermeiros em sua atividade de supervisão:

a) representam a administração frente ao pessoal de execução e opera- 
cão, pois são eles que verificam se as regras, os regulamentos, procedimen tos:politicos e diretrizes vindo de cima para baixo, estão sendo cumpridos;

b) precisam reconhecer o trabalho que supervisionam com relativa profundidade, necessitando de habilidade técnica para poder instruir, desenvolver, dirigir e avaliar técnicos e demais subordinados (perícia técrica) ;

c) devem se comunicar em duas linguagens distintas: a dos administradores e não administradores, que exijam abordagens diferentes quanto a motivação, comportamento e valores:

d) a.presentam dificuldades quanto à sua identificação e colocação dentro da hierarquia na empresa. Não são executores, mas tambēm não são facilmente aceitos pelos outros administradores de nivel mais elevado;

A exigéncia, por um lado da administração, para que a tarefa se cumpra e, de outro lado, a sua relação com os subordinados, que querem ser tratados como seres humanos e que se considerem os seus sentimentos, colocam os supervisores numa situação de conflito de papéis de difícil solução.

e) tièm a sua autoridade restringida, embora, em muitas empresas pequenas, os supervisores podem ter autoridade completa na sua área de atuação. Em muitos casos os supervisores ficam na fatia do meio do sanduiche, recebendo pressāo dos dois lados: um, representando os interesses da administração e, outro lado,o interesse dos empregados.

Muitos supervisores, no caso das empresas, são promovidos e nomeados das fileiras de funcionários mais häbeis e ou experientes, diferentemente dos enfermeiros que assumem esta atividade, recém egressos de uma faculdade; isto, muitas vezes se deve à falha em toirnä-lo um perito nas atividades desenvolvidas pelos auxiliares de saúde, seus subordinados, em um serviço, que nem sequer tem um treinamento inicial (em muitos municipios os enfermeiros entrevistados eram pioneiros na Secretaria ou Departamento de Saúde; assumiam essa função agravando a crise de identidade e ou o conflito de papéis.)

Uma outra linha de anāilise apresenta GORZ ${ }^{39}$ ao discutir o papel do técnico na gestão, considerando que, mesmo em empresas que não são suficientemente racionalizadas, o mal estar dos técnicos tem motivos estruturais ligados ao tipo existente da divisāo do trabalho e não como fazem os tecnocratas - em que todos os problemas não passam de problemas de orgaıi ização.

GONCALVES ${ }^{56}$, ao analisar as características tecnolögicas do trabalho de enfermeiros em 11 Centros de Saúde de São Paulo, observa que o 
termo supervisão engloba técnicas burocräticas - autoritárias, como o controle de livro ponto, horário de funcionärio, que são rejeitados como "atividade vil e ocultado sob a supervisão como forma de contornar a rejeição."

Parece que os profissionais não entendem que supervisão e controle são dimensões de um mesmo objeto, distinguỉveis por anālise, mas inseparáveis na prática.

Nesse estudo, as atividades de controle aparecem nos enfermeiros que exerciam função de chefia, mas näo foram referidas em grande proporção como atividades dos demais enfermeiros, que tinham sob sua responsabilidade um grande nümero de auxiliares de saüde, parecendo que ou não era exigida do pessoal ou estava jä incorporada na supervisão.

Nesse trabalho não se optou por um modelo de supervisão para se analisar a forma como essa atividade é desenvolvida entre os enfermeiros entrevistados, depreendidos da transcrição dos depoimentos. Adotando-se os pressupostos explicitados por SILVA 114 - "Não considero como vālidos regras ou modelos de supervisão construídos "a priori" a partir de idéias sobre o que $\bar{e}$ ou como esta deve se dar. Penso que em relação a esta atividade o concreto do processo de trabalho fala mais alto, impõe caracteristicas e limitações à supervisāo, sendo tambēm determinado pelo concreto da vida dos trabalhadores, com sua subjetividade, seu envolvimento, sua alienaçāo, sua sociabilidade e historicidade... vale destacar ainda que entendo a supervisão em âmbito mais restrito, como uma das atividades do processo administrativo gerencial e de controle do processo de trabalho. Sendo que na enfermagem, este polo mais intelectual, de poder e controle do trabalho, é ocupado historicamente pelas enfermeiras."

\subsubsection{Organizacāo do servico/Relatórios e Escalas}

Nesta categoria da anālise foram enquadradas as questões administrativas do posto, que foram relacionadas pelos enfermeiros apresentados na metodologia. No periodo pesquisado, o único serviço que dispunha de auxiliar administrativo era o de Curitiba.

Os depoimentos estão relacionados abaixo:

a) Controle de Medicamentos, Material, Equipamentos.

"Controle de medicamentos, controle de material, de estoque, controle de quantas gazes entram, controle de quantas saem..."

"Todo o controle da parte de material, todo um encaminhamento, por exemplo, tá faltando material, tá com falha em determinado aparelho..."

"Levando vacina para um..." 
"Levantamento de material que falta na unidade... passamos na unidade e fazemos o levantamento do que falta e providenciamos diretamente com 0 almoxarifado."

b) Organizacão de fichärio.

"Organizar o fichārio, tem um fichārio de... um fichārio que tem o pré -natal, puericultura, aprazamentos.".

c) Controle do trabalho da Zeladora, Vigia e Jardineiro.

"... quando preciso ensinar a zeladora como faz uma limpeza, eu vou e ensino, faço 0 trabalho da zeladora... se ela gasta demais, se ela gasta de menos, manutencão de materiais."

"... toda questão administrativa de um posto de saúde fica sob supervisão da gente, inclusive a questão do guarda do posto, zelador."

e) Implantacão de rotinas.

"A gente está tentando implantar rotinas novas..."

f) Encaminhamentos.

"Falta de vaga, então a gente dá um jeito de encontrar um outro hospital."

g) Transporte para pacientes que necessitam de encaminhamento.

"Carro para pegar pacientes."

Há mais de 20 anos, diferentes estudos, na área hospitalar e de saúde püblica, mostram grande parte do tempo dos enfermeiros dedicados a atividades de economato como: Zeladoria, Jardinaria, e Administrativas: manutencão, controle de material, equipamentos etc. com diferentes explicaçoes para essa situação 29 . Também nos Estados Unidos $2 / 3$ de jornada de trabalho diário é gasto em atividades de economato e controle burocrático. e somente $1 / 3$ em cuidados de saúde.

Parece que este fato de desempenhar funcões no trabalho, semelhantes às de seus lares, não é próprio só da enfermeira, mas também dos médico-sanitaristas. Um estudo revela que chefes dos centros de saúde de São Paulo apresentam características de feminização, quando identificam seu trabalho "como dona de casa: tem que resolver os probleminhas do dia-a-dia, falta de recursos, falta de funcionários, férias, demissões, ficar em cima do trabalho." 56

Se existe pouco preparo para desenvolver um trabalho que tenha por base a competéncia técnico científica para desenvolver programas baseado no perfil epidemiológico - năo será explicável que as enfermeiras 
se ocupem de atividades para as quais tenham formação desde a infãncia, que são as de limpeza e manutenção de cada?

Is to também se aplica ao fato de terem que assumir o comando dessas atividades quando o pessoal auxiliar de limpeza tem qualificacões insuficientes em relação ao seu pröprio trabalho.

0 trabalho da enfermeira, como o da professora e da parteira para LOPES 67 "não significa apenas uma escolha mas uma oportunidade que a mulher encontra para por em prática atitudes que aprendeu desde 0 berço: servilismo, bondade, paciēncia, dedicacão e carinho".

Em alguns municipios, o preenchimento de relatórios era delegado aos auxiliares de saūde; o enfermeiro apenas verificava e quando necessārio fazia as correçōes; um único município dispunha de auxiliar administrativo para esta atividade.

"A gente sempre checa os relatórios preenchidos pelos médicos, a gente checa os relatörios preenchidos, está checando RDTR, (notificação de doenças) que seriam aqueles de doenças transmissiveis..."

"Mexer em papel, toda a área de papel, vacinas, relatórios, acaba fazendo isso, o que é triste..."

"Relatórios de vacina. Relatório ... das AIS, todo final de més..."

"Tipo escala de funcionārio... que horārio os funcionārios vão trabalhar, horáro médico..."

"Escalas de médico e revesamento..."

As escalas eram feitas nos municipios, onde existe uma demanda maior de clientes e maior número de funcionārios, de tal forma que é necessāria uma divisão maior de tarefas e rodizio entre os mesmos. Essas não se justificam onde um ünico agente de saūde ē responsāvel por todas atividades de enfermagem ou em alguns locais, como postos de saúde em Londrina, que, mesmo com mais de um funcionário, conservam caracteristicas de trabalho polivalente, isto $\bar{e}, 0$ atendimento ao cliente $\bar{e}$ feito pela ordem de chegada do cliente, não sendo designado um auxiliar de saúde para determinado procedimento, mas todos dominam e atendem dentro de suas atribuiçōes ou fazem os encaminhamentos necessārios.

\subsubsection{Coordenação de Programas}

Entre suas atividades administrativas, enfermeiros mencionaram a coordenação de programas. Isso pode estar associado à existēncia de poucos servicos em que havia uma programação de trabalho sob responsabilidade desses profissionais, como no caso do Municipio de Curitiba. 
Os programas encontrados sob responsabilidade do enfermeiro são os voltados para o grupo materno-infantil e de doenças crönico-degenerativas, como o controle de hipertensão e diabetes, porque tais programas incluem o atendimento de enfermagem feito pelo auxiliar de saúde.

"Coordenaçāo de programas è. que è a parte de puericultura, programa com gestante e a supervisāo também do programa de hipertensos."

"Eu acompanho todos esses programas. Então eu tenho a função de coordenacão do programa de lactente que tem as crianças e eu acompanho todo esse programa, treino a equipe pra trabalhar com o programa."

"Presto assistência junto, dentro do programa. Faço atendimento à crianças, atendimento de enfermagem às māes, palestras, organizo os grupos, as reuniōes e o programa de hipertenso, eu faço a parte só de organização de grupos, das atendentes. Faço orientação assim, mas não me envolvo muito..." (o programa de hipertensos era de responsabilidade da chefia do posto que poderia ser médico ou enfermeiro; no caso a chefia era médica, o que explica o pouco envolvimento).

\subsubsection{Chefia do posto}

Entre as funções administrativas a chefia do posto foi mencionada por $25,6 \%$ do total de pesquisados. Dos trés municipios, onde os enfermeiros exerciam esta função, em apenas um deles o cargo era definido por Lei Municipal. Este municīpio, na gestão municipal 1982-1988, tinha colocado os enfermeiros como chefe dos postos, mas, no período pesquisado, ocupavam este cargo somente um pouco mais da metade $(51,2 \%)$.

Em outros municipios, os enfermeiros, apesar de se auto deno minarem coordenadores ou supervisores de enfermagem, eram de fato chefes de posto, pois tinham sob sua responsabilidade todos os recursos humanos, incluindo o controle de horário de trabaiho dos médicos.

"Eu sou supervisora do servico e não sou só supervisora de enfermagem, sou supervisora dos auxiliares de saúde, dos médicos, dos dentistas, sou supervisora geral, do serviço, (aqui referindo-se ao posto onde atua).

"[a chefia]... Tem duas partes o todo, a parte administrativa: a gente faz toda a coordenacão do posto pelo controle das funçōes das atendentes de saūde: supervisão, orientacão, distribuição, pelos despachos da coordenaçāo meśmo do pessoal, da parte médica também, de controle de férias, saijdas e de toda programação do trabalho que é desenvolvido. No mais, especial, eu tenho os programas. Nós temos programas de gestantes, hipertensos e lactentes. 0 programa com as palestras e com orientação que 
tenho que fazer no programa de lactentes. 0 programa de hipertensos, às vezes é o médico que faz; e o programa da gestante também divido com o médico.

"A função de chefia è da enfermeira, Você atua em parte numa coisa em parte noutra. É dificil então a parte de enfermeira mesmo. Às vezes você deixa um pouquinho, você faz bem a parte do papel, (registros). Acho que é uma dificuldade que a gente sente. Eu faço parte da chefia, a parte do planejamento, a parte de repasse de informaçoes, mais a parte administrativa de chefia. Acho que mais importante é atuar como enfermeira, que planejamento das atividades..."

"... a gente não consegue nem ser enfermeira e nem ser chefe porque è muita atribuição pra uma pessoa sō."

"É a coordenação da equipe de enfermagem e da equipe toda do Centro de Saúde, incluindo os médicos e demais funcionários, no caso, servente, escriturārio, etc., dentro disso a gente procura definir funçōes que vem mais ou menos definidas da prefeitura, mas repassar isso internamente também; é fazer as escalas, as rotinas, a parte mais de coordenação mesmo do trabalho, fazemos reuniōes, geralmente duas reuniōes por més, pra discutir rotinas e atividades internas dessa equipe e toda parte assim de controle de frequéncia... e demais problemas administrativos assim da equipe."

"Na parte administrativa: escala de auxiliares, controle de férias dos auxiliares, gräfico da cobertura, vacina, produtividade da Unidade, checagem do número de auxiliares em relação a produtividade, avaliaçāo da qualidade do servico, porque na hora de contratar novos auxiliares a gente pensa muito em relação a qualidade - vocé tem que ter um certo parámetro como é que está a nossa produtividade? Será que a gente precisa de um novo auxiliar?".

CHIAVENATO $^{32}$ considera a geréncia como a função de direção exercida no nível intermediārio da empresa, subordinando-se aos diretores e dirigindo outros executivos (supervisores). "A tarefa básica seria a mediação, isto $\bar{e}$, a redução da incerteza trazida do ambiente da tarefa pelo nivel institucional e sua colocação em termos de programas e operação padronizados e estandartizados ao nivel operacional. Ainda teriam sob sua responsabilidade o planejamento e a condução da atividade humana Imotivação, liderança e comunicaçãol".

A ênfase é dada no conhecimento que o gerente tem sobre as pessoas. A psicologia e a sociologia seriam as ciências que contribuiriam para um melhor ciesempenho do mesmo.

Os enfermeiros relacionaram como atividades desenvolvidas 
nessa função de geréncia, variando de entrevistado para entrevistado e não de forma constante (como na análise dos demais depoimentos), as seguintes:

- planejamento das atividades a serem executadas pelos postos de saúde;

- coordenação de programas: gestantes, lactentes, hipertensos, esçolares e creches;

- avaliação quantitativa e qualitativa;

- controle de pessoal (em sentido estrito): médico, pessoal de enfermagem, zeladores, jardineiros, vigias e auxiliares administrativos;

- controle de material: medicamentos, equipamentos, manutenção;

- comunicação: relatórios, reuniões, repasse de informações ao nível central e com a equipe;

- estabelecimento de vínculos entre o posto de saúde e a comunidade.

"Uma funçāo ē realmente a parte de chefia e dentro da chefia a gente acaba assumindo a parte de gerēncia: reuniōes, fazendo realmente uma programação, mantendo maior contato com os médicos e atendentes na parte administrativa e depois realmente a parte de atividades técnicas de enfermeira como supervisora".

LOPES" $^{66}$ afirma que "a indefinição de papēis a nēvel profissional tem sido uma queixa constante. A meu ver essa indefinição não existe; 0 que estā dado $\bar{e}$ a negação da contradição entre o discurso da teoria - ou a ideologia teōrica - e a realidade concreta. Um quadro construỉdo a partir de uma visão idealizada da profissão se contrapōe a um dia -a-dia que nada tem de poētico. A realidade mostra um ramo de trabalho feminino, explorado, gerador de tensöes com carga excessiva de trabalho, mal remunerado e com pouquéssimo poder de barganha frente à classe dominante".

0 acümulo dessas funções para alguns leva a um conflito de papéis "eu sou chefe primeiramente, então fica tudo muito misturado... a gente nāo consegue nem ser enfermeira e nem ser chefe, porque è muita atribuição para um só pessoa" (o posto funciona em três turnos).

Esse elo de ligação do técnico com a instituição, a integração das incertezas, è reconhecido quando o enfermeiro diz: "Eu sou responsável pelo Centro de Saúde, eu sou como eu diria... a pessoa, o elo. 0 elo da Secretaria com os funcionários, tó representando a Secretaria aqui ..."

Esse reconhecimento não corresponde à utilização desse poder dado pelo cargo, quando se discute a participação dos profissionais na programação e em consequéncia na tomada de decisão na Tabela no 13. 
4.4.1.5. Reuniöès com a equipe

Essas reuniōes têm como objetivo discutir assuntos administrativos e assuntos técnicos com a finalidade educativa na complementação ou atualização dos auxiliares de saúde.

"Fazemos reuniōes, geralmente duas reuniōes por mês pra discutir rotinas e atividades internas dessa equipe".

"... reuniōes com a equipe sobre todos os tipos de assuntos assim... assuntos administrativos e assuntos técnicos também, a gente tá começando agora... faz pouco tempo que eu estou aqui, a gente tá comecando a fazer uma vez por semana, fazer uma reuniāo... pra treinamento, então pra discutir é... doenças simples, discutir pré consulta, como é que a atendente deve fazer essa pré-consulta, discutir vacina, reidrataçāo oral..."

"... aqui dentro eu organizo reuniōes, também é aquele entrosamento entre a equipe, é passar recados, é organizar as nossas reuniōes de planejamento, de tudo também..."

Os médicos sanitaristas na rede de Centros de Saúde de são Paulo utilizavam tambēm as reuniōes internas como instrumento de trabalho para solução de problemas de natureza administrativa ${ }^{56}$. São também caractëristicas tecnológicas do processo de trabalho das chefias dos centros de Saúde: A comunicação ascendente ou descendente é dentro de uma organização o que coloca os planos ou programas em funcionamento. Esse trabalho passa a ter características de treinamento em servico, face ao não preparo do pessoal auxiliar.

\subsubsection{Atividades Assistenciais}

QUADRO 6 - Nümero e porcentagem de enfermeiros que declararam desempenhar atividades assistenciais intra-postos de saúde, em 22 municipios do Paraná, 1988.

\begin{tabular}{lcc}
\hline ATIVIDADES ASSISTENCIAIS & № & $\%$ \\
\hline Atendimento de enfermagem & 98 & 83,8 \\
Consulta de enfermagem & 19 & 16,2 \\
Visita domiciliar & 16 & 13,7 \\
\hline
\end{tabular}




\subsubsection{Atendimento de Enfermagem}

0 atendimento de enfermagem. obteve um alto percentual de afirmativas, onde $83,8 \%$ dos enfermeiros responderam que o faziam. Esse alto percentual pode estar associado ao fato de que o roteiro de entrevista incluia uma questão especifica sobre essa atividade, com o objetivo de se verificar se a enfermeira prestava "cuidado direto" ou alguma função ampliada proposta pela Assistência Sanitäria Primária. NAKAMAE ${ }^{89}$ define 0 cuidado direto prestado pelo enfermeiro como sendo prática individualizada ou execucão conjunta com o pessoal auxiliar, das ações de enfermagem numa relação imediata profissional-cliente.

Os atendimentos, relacionados nessa pesquisa, em sua maioria são präticas delegadas aos auxiliares de saüde e não uma ação conjunta com esses ocupacionais.

Numa visão mais estrita que a da autora acima citada, quando questionadas se essas atividades eram exclusivamente suas, apenas $16,2 \%$ responderam afirmativamente e foram categorizadas como consulta de enfermagem.

A falta de recursos humanos para atender a demanda e ou a forma como eram ofertados os serviços (em muitos locais a coleta de exames, a marcação de consultas concentram-se pela manhã e no período da tarde, muitas vezes, os postos de saüde diminuem bastante o seu fluxo), exigem que o enfermeiro substitua o auxiliar em suas atividades, não eventualmente, mas de forma rotineira, contrariando a lógica da racionalidade capitalista, que ao fragmentar e parcializar as tarefas, espera que um profissional mais caro exerca funcões diferentes de um ocupacional que recebe um menor salärio. Muitas empresas americanas mantém cläusulas contratuais que impedem o supervisor de exercer tarefas dos seus subordinados 15 .

0 atendimento de enfermagem, como a supervisāo, tambēm se apresentou de diferentes formas, tanto em relação ao que era feito como em relação ao momento em que era realizado.

Os depoimentos dos profissionais, quanto ao que era feito, seguem abaixo:

Os tipos de atendimentos de enfermagem:

"... Faco atendimento ao paciente, nunca deixei de fazer, aplicando uma vacina, fazendo uma injeção, fazendo sempre alguma coisa. Vocé nāo pode só naquela assim de ficar olhando, não dá."

"... Eu faço assisténcia, por exemplo. [o atendente] não consegue definir o que tinha... uma assadura, se é dermatite ou monilia, entāo eu 
vou, ajudo, identifico, a gente faz os cuidados..."

... "Faço [atendimento] por enquanto só com criança, a criança sadia, controle de saúde."

.... "Vacinas, BCG, sou eu, porque por enquanto sou eu que faço. Não tem nenhuma funcionāria treinada. A menina aì faz pouco tempo que está com a gente, entāo sou eu que faço. Orientação de pós-consulta, mesmo a préconsulta as vezes eu faço também..."

... "Faço alguns atendimentos individuais como no caso do programa do escolar que eles [atendentes] fazem a triagem e dai tem dúvida, o cliente que eu atendo è aquele que pede consulta que nāo tem mais, que eu vejo que o caso nāo è simples e que precisa de um agendamento..."

:... "Atividades diretas com o paciente elas são muito esporádicas, sabe, estāo lidando com uma coisa mais séria..."

$\because .$. "As vezes eu tō andando e vejo alguém que tá preparando prá fazer uma nebulização eu vou, faço..."

"A parte de dieta é minha ou assim uma outra orientacão mais aprimorada (diabético, ou hipertenso) em pós-consulta... uma prē..."

.... Ajudo na pré-consulta, eu tenho que ajudar na pré-consulta de todos os postos. 0 contato mais direto que eu tenho com a populaçāo é isso."

... "Tenho um posto na zona urbana que a gente tá fazendo puericultura... daī nesse posto eu vou uma vez por semana e fico só fazendo puericultura, junto com os agentes de saúde."

... "hả ausência do médico, daī sou eu que faço o atendimento à gestante..."

... "as patologias delegadas das doenças mais comuns eu faço..."

... "quem faz os eletrocardiogramas sou eu."

"... ele [médico] pede para fazer um debridamento, eu faço, desde que ele esteja do lado [consultório]... eu fiz a anestesia, ele estā aī do lado."

"Eu presto assistência de enfermagem bastante, mas a gente não está desenvolvendo consulta de enfermagem, a atividade basicamente è do auxiliar... mas assim, quando chega uma crise convulsiva, então é... nāo tem médico, então eu, sabe, assumo... a gente aplica Valium. As meninas não fazem isso, mas eu faço, tá."

"Desde marcar consulta, faço vacina, faço [coleta] exames complemen- 
tares, è verificar pressão, fazer injeção, toda e qualquer atividade."

"Eu tenho atendimento no interior. 0 ūitimo, que faleceu, tinha cáncer ue esōfago, então è não podia mais engolir nada, então eu ia lá todos os dias fazer um litro de soro. Todos os dias eu aplicava e o agente de saúde ficava cuidando."

"Não tem nada exclusivo. A gente atende aquilo que se chama patologia delegada - praticamente aqui a Secretaria jā estipulou para os auxiliares trés tipos de patologia delegada; pediculose, verminose com comprovante do resultado parasitológico e a escabiose." (Enfermeira responsável pela chefia do posto e as atividades delegadas são normatizadas pela equipe em nivel central da Secretaria de Saúde).

"Eu faço pré-consulta, injeção, curativo, eu faço tudo."

Momentos em que são feitos os atendimentos:

a) Atendimentos em caso de dūvidas.

"Eu faço assim... aparecem as meninas, querem tirar alguma dúvida..."

b) Atendimentos em carāter de substituição ao auxiliar de saúde.

"Quando eu estou ali tem uma pessoa ali esperando, às vezes as meninas tão fazendo outra coisa, eu vou là e faço..."

"Quando falta pessoal eu acabo ajudando mesmo... na ausência do médico, daī sou eu, faço o atendimento de gestantes."

c) Atendimentos para manter a habilidade e gostar da prática.

"Pela demanda e porque gosto, sabe ainda mais que fiquei muito tempo afastada, eu sinto necessidade, sabe, técnica da coisa ou de identificar mais com a comunidade."

d) Atendimentos em casos de urgência ou não padronizados.

"Eu tenho atendimento ao acaso, quando chega alguma urgência, uma emergência ou encaminhamento e ninguém sabe resolver, aī eu resolvo e intervenho."

e) Atendimento para treinamento de novas atividades.

"Na maioria das vezes, eu faço o primeiro, para quem tiver escalado prá 1ā, jā ir aprendendo e fazendo."

f) Atendimento para triagem.

"0 cliente, que su atendo, $\overline{\mathrm{e}}$ aquele que pede consulta que nāo tem mais, que eu vejo que o caso não é simples e que precisa de um agendamento, talvez o agendamento tem que ser breve..." 
g) Atendimento em horas de trabalho disponiveis.

"Quando eu estou no postinho, se não estou fazendo alguma orientação ao funcionário, então eu estou fazendo o atendimento do paciente."

Os enfermeiros entrevistados, em uma alta proporção $(83,7 \%)$, afirmam prestar a assisténcia, mas esta não é exercida de forma rotineira. Poucos municipios apresentavam condiçōes quanto à equipe para que tal acontecesse e isso confirma a tese de ALMEIDA $^{6}$, quando discute as origens e composição da força de trabalho na enfermagem: as que seriam as "ladies nurses" (as que pensavam o cuidado) e as "sister nurses" ou mesmo reforcando a concepcão de supervisor de lá linha de CHIAVENATO $^{18}$, que substitui o pessoal na produçāo ou é responsável pelo seu treinamento.

"Vocē acaba assumindo a atividade como se vocē fosse um auxiliar de saúde, tā?"

"... eu acho que eu faço mais assistēncia do que a pröpria coordenacão do posto, das atividades de enfermagem no posto pela própria conjuntura, sabe eu deixo de coordenar para atender..."

STEAGALL-GOMES ${ }^{121}$ que entre os enfermeiros chefes e/ou com a encarregatura na DRS6-Ribeirão Preto, dentre as funçōes que mais executavam estavam as de assistēncia de enfermagem com $73,3 \%$ e não as administrativas, como seria o esperado. Esta atuação era explicada pela caréncia de pessoal auxiliar.

A propósito, sabe-se que também os sanitaristas (médicos) de Centros de Saúde do Estado de São Paulo apresentavam como compondo a maior parte do seu trabalho, entre os classificados como muito frequentes, o atendimento a clientes por meio de consultas médicas em carāter eventual como substituicão: falta, férias, licenças ou suplementarmente devido a excesso de demanda, justificando tal ação como necessidade técnica individual para manter a prätica ou necessidade de satisfacão afetiva "faço porque gosto" 56 .

Esse papel de substituição e suplementação eventual parece caracterizar o processo de trabalho das chefias em postos de saúde, seja ele de enfermeiros ou de médicos do Paraná ou São Paulo. 


\subsubsection{Consulta de Enfermagem}

Uma pequena proporcão de enfermeiros informou que realizava consulta de enfermagem, definida aqui como atividade privativa do enfermeiro no atendimento ao cliente, não delegāvel a outros.

A hipōtese era que 0 atendimento ao cliente, como atividade específica do enfermeiro, inexistia nos postos de saúde da rede municipal estudada, tendo em vista o pequeno número de enfermeiros em relacão ao grande número de postos e pessoal auxiliar, exigindo que o seu tempo fosse voltado para as funçōes de treinamento e supervisão. Pela nossa experiência e contatos com a rede de postos e escolas de enfermagem da região Norte do Paraná, sabiamos previamente que nenhum servico ou escola de enfermagem da região tinha a proposta de enfermeiro fazendo consulta de enfermagem.

Isso não se confirmou, porque em toda a rede de postos de um municipio os profissionais afirmavam fazer consulta de enfermagem (11 enfermeiros) e, em outro município próximo a esse, tambēm os enfermeiros tinham como atividade a consulta de enfermagem. 0 denominador comum è que eram em sua maioria egressos da mesma escola de enfermagem.

As consultas de enfermagem, segundo seus depoimentos, eram feitas nas seguintes situaçōes:

"... por exemplo hoje nós temos o planejamento familiar. A gente faz entrevista, reūne os grupos que passam por exames médicos e depois da orientação necessária sobre todos os métodos, é feita individualmente a escolna do método adequado..."

"Na parte volante nós temos a kombi toda equipada. Essa kombi leva o atendente e nós fazemos consulta de enfermagem. Nāo vai nenhum médico."

"Por exemplo uma gestante que me procura aqui, jā com teste de gravidez ou suspeita de gravidez, então eu faço toda a consulta de enfermagem, e depois ela è encaminhada para médico."

"Ela faz todas as vacinas e a puericultura até dois anos com a minha orientacão. Os desnutridos passam comigo 3 vezes por mês e, dependendo do caso, ele passa uma vez omédico. 0 grupo de criancas tem um atendimento individual comigo... uma vez por semana, (mães) participam de um curso."

"... mas também a consulta de adultos e dos hipertensos."

"... especificamente do escolar, eles passam por mim todas as criancas que tém problema de aprelidizado, de rendimento escolar... eu atendo gestantes conforme a semana, digamos a gente tem um grupo de gestantes, quando é o primeiro trimestre, no segundo trimestre, algumas passam. 
pelo médico com 32 semanas e com 28 semanas, as outras... as sadias comigo... 36 semanas em diante só com o ginecologista."

FRANCO $^{48}$ situa a origem da consulta de enfermagem no Brasil em 1966, na Fundação SESP no atendimento a gestantes e crianças sadias e, por ter-se difundido mais na área de Saúde Püblica, o alvo eram as populaçōes carentes.

A consulta de enfermagem como atividade prōpria do enfermeiro é defendida com os argumentos de que è necessário fazer o enfermeiro ter contato com o doente para ter o reconhecimento profissional e/ou aprofundar-se em seu próprio campo de saber.

Em nenhum período da história da enfermagem brasileira, o enfermeiro exerceu predominantemente o cuidado direto ao paciente ${ }^{6}$.

No salto da enfermagem tradicional para a moderna, o objeto de trabalho do enfermeiro se transformou, não se constituindo mais no cuidado direto.

NAKAMAE $^{49}$ considera que o resgate do cuidado direto não implica na renüncia ao cuidado indireto e pressupōe que possa haver uma ruptura da divisāo trabalho manual/trabalho intelectual, que igualmente supõe a superação desta sociedade dividida em classes e com interesses antagónicos. Ao nosso ver, como utopia e uma imagem projetada ao longo do horizonte, essa proposta pode ser discutida, mas nunca como possibilidade concreta imediata para a categoria como um todo. As experiéncias do enfermeiro, prestando cuidados diretos, são em centros maiores, e que nāo podem ser extrapoladas para os demais estados e municipios brasileiros.

Por outro lado, o enfoque que se tem do trabalho do enfermeiro de Saúde Pública não sendo único, dificulta a formação dos enfermeiros. Essas divergéncias hä mais de 10 anos permeiam duas entidades americanas a A.N.A. (American Nurse Association) e a A.P.H.A. (American Public Health Association). A A.N.A. considera o individuo ou a familia, como a unidade de análise e como prática para melhorar a saúde da comunidade. A A.P.H.A. identifica como objeto; os grupos de risco, assumindo que a melhoria do estado de saúde da comunidade como um todo é que beneficiará os seus membros.

A absorcão das teorias americanas reflete-se na formação profissional no Brasil. Essas diferencas aparecem, quando os modelos assistenciais implantados atendem a demanda espontānea, sem preocupar-se com programas, passando a assisténcia de enfermagem a ser individualizada. 


\subsubsection{Visita Domiciliāria}

A Visita Domiciliäria ${ }^{40}$ era definida por uma Secretaria Municipal de Saúde estudada como "a ida de qualquer um dos membros da equipe de saüde ao domicīlio de moradores da ārea de abrangéncia." As visitias domiciliares nesse municipio podiam ser a:

a) pacientes inscritos no programa: A todos os pacientes, pelo menos uma vez, entre a inscrição e a alta do programa e visitas esnecíficas dentro dos programas.

b) convocação de faltosos a vacinas

c) acompanhamento clīnico: Realizadas a pedido do médico para seguimento da evolução clínica de alguns pacientes.

Essa classificação permeava as concepcõos do que era essa atividade para a maioria dos entrevistados.

A visita domiciliária relatada pelos entrevistados pode ser classificada quanto à finalidade com que era feita em:

a) Casos em que o cliente não pode ir até o posto de Saúde

"Casos pós-cirúrgicos: casos de pacientes necessitados assim, em termos de alimentação, essas pessoas mais pobres que não estāo tendo assistência, paciente doente acamado, nāo estāo tendo condiçōes de vir ao Posto, a gente vai..."

"A gente tem visita domiciliar... tem um número pequeno... eu estava fora porque fui ver caso de uma paciente nossa que é diabética e ela teve uma queda, daī eu fui fazer insulina, casos solicitados, agora, programa nanhum."

b) Cadastrando e Recadastrando a área.

"0 que eu gosto muito de fazer é visita domiciliar, nós estamos recadas trando a área, são 800 famīlias cadastradas, acho que a gente jā recadastrou mais ou menos 500 famīlias, então tem escala, cada dia sai uma dupla."

"A visita aqui é para fazer a ficha do posto, a ficha famīlia é feita na casa. A pessoa vem solicitar, a gente visita, preenche a ficha na casa e atendemos só nossa ārea de abrangéncia. (Curitiba).

c) Chamando faltosos

"Se tem gestante faltosa, procuramos essa faltosa que nāo participa do grupo. Aquelas que vieram uma vez, mas que nāo tiveam retorno. Da crian ca na puericultura e no grupo de hipertensos também."

"Casos de atrasio sāo só fétos dentro da cidade, ainda estão muito limitados, porque näo tem dado tempo imesmo. Agora sāo feitos pelos auxi- 
liares convocacão da vacina, de pré-natal, de hipertensos, mas só dentro da cidade."

d) Bloqueios na vigilância epidemiológica.

"Se teve algum caso (notificação) a gente, que faz a visita, vai na casa, faz o bloqueio."

As justificativas de alguns entrevistados da atividade nāo estar sendo realizada, pelo pessoal auxiliar:

"Hoje para fazer visita domiciliāria é difícil porque o pessoal não conhece, [ärea] tem que ir alguém que conheça junto e tal."

"Mas é pequena (poucas visitas) porque a àrea é de muito difícil acesso, ela é um morro. Então tem que subir, descer värias vezes. Então nas proximidades a gente visita, mas nos lugares mais longe a gente manda aerogramas ou manda recados, mas geralmente aerogramas."

"0 atendente de saúde não tem assim essa vontade, esse empenho de fazer uma visita domiciliar, de vocé ir lá conversar com a pessoa, explicar, orientar alguma coisa. Eles mesmos tém dúvidas, às vezes um funcionário vai pra área fazer uma visita de atraso de carteirinha, mesmo, eles chegam lā, eles ficam atē mésmo em dúvida, eles nāo tem segurança daquilo."

"Então o pessoal lá (outro posto onde trabalhou anteriormente) tem jeito de conversar com a comunidade, aqui o pessoal não tem, é uma coisa muito fria, assim não tem aquele envolvimento, então eles vão, o chefe mandou, o enfermeiro mandou... a senhora tā atrasada..."

Reconhecendo a importāncia da visita:

"Eu faço por exemplo visita domiciliar e gosto de sentir de perto a realidade do povo, porque vocè aqui dentro é uma coisa, vocé não sabe a vida daquela pessoa fora daqui, ela vem aqui pra consulta ou pra uma orientacāo e tal, saiu daqui vocé nāo sabe, entāo nōs temos essa "varredura"...: (pesquisa nos domicīios, em determinado perīodo).

"Eu acho que é fundamental as pessoas que trabalham, no posto de saúde, conhecerem a população da ärea, então isso é uma coisa que eu tento com o pessoal apesar de nāo existir um apoio facilitando o transporte, vale transporte, alguma coisa porque a área é grande, e na verdade jā existe uma questāo de defasagem salarial que vem por trās, polītica e tal que está influenciando um outro tipo de trabalho do atendente, então, ele não quer sair para a área, é difïcil colocar para os atendentes de uma forma, digamos... assim é... pedagógica, que eles consigam entender a importāncia de incorporar dentro deste a importāncia disso.". 
Os cuidados de enfermagem no domicilio deram origem $\grave{a}$ enfermagem de Saüde Püblica. ROSEN ${ }^{108}$ mostra, ao analisar 0 aparecimento desse profissional, que as suas raizes são derivadas no Iluminismo, do desejo de melhorar o estado de saúde dos pobres, provendo-os de informação, de modo que se auto-ajudassem e, de outro lado, a tradição caritativa de prover cuidados médicos e de enfermagem para os doentes pobres.

Esforços para prover enfermagem no domicīio para doentes pobres de forma organizada foi objeto de trabalho em várias comunidades da Europa e América durante o início do século XIX, mas foi na Inglaterra que a enfermagem distrital primeiro se desenvolveu.

Entre 1854 e 1859, a Epidemiological Society of London apresentou um plano para treinamento de "mulheres pobres" para irem a comunidade e cuidarem destes doentes. Acreditava-se (ainda persiste a idéia até os nossos dias) que, sendo da mesma classe social do paciente, o trabalho seria mais efetivo. O plano faliu, e em 1859, em Liverpool, William Rathbone iniciou esquema para prover cuidados de enfermagem para os pobres.

Apōs a morte de sua esposa, que durante longa e dolorosa enfermidade foi cuidada por enfermeira treinada, ocorreu a Mr. Rathbone a idéia de que os cuidados de enfermagem poderiam aliviar os pacientes e tentou, por sua conta, a experiencia de estender esses cuidados aos pobres, contratando por 3 meses Mrs. Mary Robinson, a enfermeira que cuidou de sua esposa.

A proposta não era somente dar cuidados de enfermagem, mas ensinar às famijitas como cuidarem de suas prōprias doenças, como deixar suas casas limpas. As condicões que Mary Robinson, a primeira enfermeira distrital, encontrou entre as pessoas, que recebiam os seus cuidados, a deixaram horrorizadas. 0 sofrimento intenso, a evidente falta de esperança para dar alivio aos clientes a deixaram angustiada. Embora acostumada a doenças, sofrimento e morte, não suportou a tensão e ao final do primeiro més retornou ao seu empregador, pedindo que fosse substituida. Mr. Rathbone conseguiu convencē-la a permanecer e o experimento foi tão satisfatório, que teve interesse de expandi-10 para outros locais da cidade ${ }^{18}$.

Apesar de dificuldades e obstāculos, conseguiu que fossem treinadas enfermeiras na Liverpool Royal Infirmary e a cidade foi dividida em 18 distritos. Cada distrito tinha uma enfermeira sob a direcão de uma Lady superintendente ou algumas vezes sob um comitẽ de Ladies superintendentes. Chama a atenção que as Ladies Superintendentes não necessitavam ter qualquer treinamento ou conhecimento de enfermagem, mas experiéncias em ação social, selecionadas entre as damas da cidade. 
aparece neste século pelo crescimento do movimento de saúde da criança ${ }^{128}$. Nos Estados Unidos até a década de 1930, a maioria dos enfermeiros, eram contratados como enfermeiros padrōes pelos próprios pacientes, nos hospitais ou nos domicilios, situação que persiste até o fim da segunda guerra mundial ${ }^{16}$.

No Brasil, em 1947, MARCH $^{71}$ já considerava "o cuidado em domicilio, como velha figura de retórica que aparece periodicamente nas conferéncias sobre enfermagem aureolando a polivalência dos enfermeiros". Considera que a assistēncia doméstica ao doente nunca chegou a ser usada entre nós e que o cuidado em domicilio, que continua a fazer parte do currículo das escolas de enfermagem, já não tem utilidade prática, pois quase não è usado no trabalho de saúde pública".

Em alguns locais, em 1967 ainda persistia esta atividade como rotina de trabalho, como por exemplo na Unidade de Saüde do Tarumã, em Curitiba. Esta unidade era local de estágio da Escola de Enfermagem Madre Léonie, que sob a responsabilidade da Fundação S.E.S.P., tinha um treinamento, utilizando da Maleta da Visitadora, com toda a sua técnica. Em Londrina, em 1973, nas Unidades de Saúde, campo de estágio dos alunos do curso de enfermagem, foi implantada a Visita Domiciliäria, acreditando-se nos principios propostos por MASCARENHAS ${ }^{75}$. Segundo esse autor a diferença entre um ambulatório e um posto de saúde è que o segundo è dināmico, caracterizado pela busca ativa de casos proporcionados pelas atividades da visita domiciliar. Naquela escola foi copiado o modelo de maleta da Fundacão S.E.S.P., e os auxiliares de saúde e os alunos de enfermagem foram treinados para a utilizarememcuidados domiciliares, na época ligados ao binômio mãe/criança, realizando curativos umbilicais e em suturas de cesareanas.

0 uso das maletas, na forma antiga, foi abandonada a prätica desse atendimento ainda persiste incorporando, agora, jä um outro tipo de cuidados: aos idosos que não deambulam ou tēm dificuldade de ir até o posto, aos paraliticos por acidentes vasculares cerebrais, grupo que aparece com a mudança de estrutura etāria da populaçāo. Essas visitas são realizadas por solicitação dessa clientela.

A distāncia, segundo TEIXEIRA ${ }^{125}$, entre a residēncia e a unidade sanitäria, na zona urbana não deve ultrapassar 30 minutos, e nesse caso a visita domiciliäria também pode se tornar uma atividade menos dispendiosa, pois não envolve a necessidade de transporte. A assisténcia no domicilio passa a ser uma alternativa para muitas doenças crônicas, tendo em vista o crescente aumento dos cursos hospitalares.

A valorização das atividades internas, desde o treinamento, tanto para o enfermeiro como para o pessoal auxiliar, leva em contra partida a relegar para o segundo plano as açōes externas, tão ou mais impor- 
tantes para o trabalho em saúde pública.

MARQUES \& ENGLER ${ }^{72}$. preveem que com a difusão de novas tecnologias é possivel se fazer o controle no domicīlio de pacientes com doenças agudas e crōnicas, substituindo parcialmente o hospital e ambulatórios.

\subsubsection{Atividades Educativas}

QUADRO 7 - Nümero e porcentagem de enfermeiros que declararam exercer atividades educativas segundo o tipo de atividade, em 22 municipios do Paraná, 1988.

\begin{tabular}{lll}
\hline ATIVIDADE & № & $\%$ \\
\hline Treinamento pessoal & 59 & 50,4 \\
Grupos & 37 & 31,6
\end{tabular}

\subsubsection{Treinamento de pessoa]}

0 treinamento de pessoal, juntamente com a administração, são as duas atividades que o enfermeiro deve assumir dentro da atual composição da força de trabalho no Brasil, tendo em conta toda a sua evolução histörica e origem ${ }^{6}$.

A expansão da rede municipal e a inexistēncia de cursos para o preparo dos auxiliares, em muitos municipios, levam à necessidade de se contemplar não sō a reciclagem ou atualização, mas a formação dentro do prōprio serviço. Tais fatos justificam que $50,4 \%$ dos profissionais entrevistados o tenham relacionado entre suas atividades. Ressalta-se que em nenhum municipio desenvolvia-se o projeto de treinamento em serviço, proposto pela metodologia de capacitação ou formacão do visitador sanitário. 0 treinamento, aqui considerado, também não é o dado em treinamento formal, que utiliza o servico como campo de estágio, e prepara o auxiliar de saúde em 3 meses, mas o que poderia ser denominado como treinamento . em servico ou reciclagem de pessoal.

"O trabalho mesmo que eu tou tendo agora, toda a implantação do C.S., é mais a nīvel educativo com o pessoal... Eles nāo tem assim muito preparo, nāo trabalharam, muitos nāo trabalharam antes nada, então a gente tem revisto, tem estudado, tem feito aulas präticas, tem visto com eles."

"A outra função é a educação en servico, fazendo treinamento e reciclagem dos funcionärios..." 
"... alēm do mais tem a função de treinamento de pessoal, diariamente, mas fica difícil porque a gente tem 4 horas para cada posto, digo, para dois postos..."

"... nós fazemos uma reciclagem de 6 e 6 meses. A gente faz um aulāo assim e damos uma semana pelo menos de treinamento intensivo, todo ano a gente faz...."

"... a demanda aumentou bastante realmente com a vinda da AIS (Ações Integradas de Saūde) e o número de postos, houve necessidade de colocar mais agentes, só que aqui é muito dificil contratação, o pessoal tem primärio incompleto, é difīcil escolher quem vai ser treinado. $\bar{E}$ mais por indicação do próprio agente. Então indica, daī fazem uma entrevista com o agente e fazemos um més de avaliação. Nesse més eu vou, faço a reciclagem nos Postos, principalmente no C... que é maior, tem as demandas e é mais fácil para treinar..."

No Brasi1 ${ }^{35}$, em 1983, nos estabelecimentos para-hospitalares, o percentual de enfermeiros que indicaram como função o treinamento em servico foi mais alto com um percentual de $71,4 \%$.

0 grupo de acordo interministerial, (Ministério da Saúde, Ministério da Previdēncia e Assistência Social, Ministério da Educação e Organização Panamericana da Saúde) concebeu o projeto Larga Escala - que é uma proposta alternativa de formação e qualificação profissional de trabaThadores como atendentes, auxiliares de saúde, agentes de saüde e outras áreas como vigilāncia sanitária, odontologia, nutrição. SoUZA e col.119 descreve como uma metodologia que busca "viabilizar a interacão entre 0 sujeito e objeto no ambiente de trabalho, considerando as formas de aprender do sujeito e recorte do objeto que permitam partir do seu referencial de percepcão da realidade, sem negar seus conhecimentos da prática e senso comum, para construir novos conhecimentos mais elaborados e específicos, de acordo com a habilitação profissional."

Essa proposta, na rede municipal em estudo, è inviävel se a rede não sofrer transformaçōes como aumento do número de enfermeiros, capacitação dos instrutores para essa metodologia, nas 5 áreas propostas para o projeto: doenças transmissiveis, saúde materno-infantil, processos crōnico-degenerativos, planejamento e organização do processo de trabalho, e plano de carreira para os atuais agentes de saúde, que permita uma ascenção profissional com recompensas salariais. 


\subsubsection{Grupos}

0 trabalho com os grupos abrange sua organização com agendamento de reuniōes, captação da clientela para inscricão e palestras.

Os grupos sāo compostos por clientes oriundos dos programas implantados segundo as diretrizes nacionais, isto é, crianças, gestantes e doentes crōnico-degenerativas, (hipertensos e diabéticos). Em um único municipio, havia ainda o grupo de promotores de saúde, que era também de responsabilidade do enfermeiro.

"... grupo de hipertensos, grupo de gestantes só eu que faco..."

"... bem eu tenho grupo de gestante... grupo de hipertensos que eu estou organizando junto com os agentes de saüde..."

ADAMI $^{1}$ observou que a educação de grupos era realizada em Unidades de Saúde, que possuiam recursos humanos em maior quantidade e meThor qualidade.

GONCALVES ${ }^{56}$ diz que os enfermeiros dos Centros de Saúde de São Paulo conservavam para si áreas que consideram nobres, como o trabaTho em grupo.

Num dos municipios estudados, o trabalho com crianças e gestantes era realizado em grupos sob a responsabilidade do enfermeiro e assistente social e em outro havia uma divisão de trabalho entre enfermeiros e mëdicos.

0 trabalho em grupo requer com efeito maior experiéncia que os procedimentos realizados pelos auxiliares de saüde, com treinamento de 3 meses em mëdia, como esterilização, curativos simples, aplicação de injeções.

Muitas vezes, o enfermeiro, baseando-se em técnicas de dināmica de grupos, utilizam-nas sem às adaptaçōes para a população alvo.

Não foi explicada a forma como é feito esse trabalho mas, toda a dinámica grupal necessita no minimo que se tenha para o seu desenvolvimento metodologia de auténtica educação dialógica como a proposta por FREIRE 50 "em que a tarefa do educador $\bar{e}$ a de problematizar aos educandos o conteūdo que os mediatiza, e não a de dissertar sōbre êle, de dálo, de estendê-lo, de entregā-lo, como se tratasse de algo jā feito, elaborado, acabado, terminado. Neste ato de problematizar os educandos, êle se encontra igualmente problematizado.

A problematização é a tal ponto dialētica, que serā impossīvel alguém estabelecé-la sem comprometer-se com seu processo."

0 trabalho de educacão é dialético com o aprendiz e sua realidade, que 0 leva a plena compreensão do processo (e não mera transmissão ou transfe- 
réncia, ou modelação de comportamento).

\subsubsection{Pesquisa e outras atividades}

QUADRO 8 - Nümero e porcentagem de enfermeiros que executam atividades de pesquisa e outras, intra-posto de saüde, em 22 municípios do $\mathrm{Pa}-$ raná, 1988.

\begin{tabular}{ccc}
\hline ATIVIDADES & № & $\%$ \\
\hline Pesquisa & 05 & 4,2 \\
Outras* & 06 & 5,1 \\
\hline
\end{tabular}

*Outras: Bloqueios, seleção de pessoal, cadastro da ärea, exame pré-admissional, palestras para a comunidade.

0 percentual de enfermeiros, que realizavam atividades de pesquisa, era pequeno. Essa atividade, em serviços que não têm por finalidade a investigação e sim a assisténcia, não tem muita chance de ter alta frequéncia, levando-se em consideração os dados anteriormente apresentados como: nümero de postos para supervisionar, número de atividades desenvolvidas, horas contratuais, número de profissionais recém-graduados.

Em 1983, nos estabelecimentos de saúde brasileiros (incluin do-se os hospitais) o percentual de enfermeiros, que não realizavam trabaTho de pesquisa, era de $72,5 \%$ e dos que realizavam, $10,4 \%$ o faziam de forma eventual ${ }^{35}$.

BURLAMAQUE e col. ${ }^{21}$, estudando a produção científica, dos enfermeiros do Rio Grande do Sul, encontrou que entre os fatores que mais contribuiram para limitar a produção estavam a falta de tempo, o custo e o pouco domínio da metodologia, motivos também descritos por CAMARGO e col. ${ }^{23}$, em Santa Catarina.

LOPES apud BOEMER e col. ${ }^{17}$, estudando a produção de enfermeiros assistenciais em relação a pesquisa, identifica fatores limitantes para o desenvolvimento do profissional nessa área, como o desinteresse da instituição empregadora, alta rotatividade nos serviços, turnos de trabaTho inconstantes, sobrecarga de atividades, falta de conhecimentos sobre metodologia de pesquisa, inexistencia de bibliotecas e, com tudo isso, se consideram marginalizados desse processo.

RIBEIRO \& GOULART ${ }^{104}$ consideram a pesquisa cientifica em enfermagem como indissociāvel do ensino e da pesquisa.

A Universidade, no Brasil, è o "locus" da produção intelec- 
tual como demonstra GERMANO ${ }^{54}$ ao analisar as publicaçōes na Revista Brasileira de enfermagem, no período compreendido entre 1955-1980, mostrando que 3 escolas exercem à liderança dessa produção; Escola de Enfermagens da Universidade de São Paulo (25,8\% dos artigos) criada em 1942, a Escola de Enfermagem de Ribeirāo Preto, $(20,8 \%)$ que data de 1951 e a Escola de Enfermagem Ana Néri de UFRJ $(11,3 \%)$ criada em 1922. Os articulistas, no perīodo estudado, eram de escolas na proporção de $48,4 \%$ e apenas $7 \%$ eram enfermeiros assistenciais, configurando-se uma hierarquia intelectual, segundo a autora, no conceito gramsciano, os que pensam e difundem o saber (docentes) e os que o executam (enfermeiros assistenciais).

As trés escolas situam-se no eixo Rio-São Paulo, estados mais desenvolvidos e são instituições mantidas pelo governo estadual e federal.

A evolução histórica e estrutura organizacional das escolas paranaenses podem explicar a pouca tradição de pesquisa mesmo entre os docentes e a sua qualificação nessa área: o ensino, por 17 anos, em uma única escola privada; posteriormente a adoção nas escolas estaduais e federais, de um plano de carreira, que não estimulava a participação em cursos de pös-graduação como mestrados e doutorados, pois a ascenção era realizada por tempo de serviço; o regime de 40 horas semanais näo estava condicionado à produçāo científica e a dupla entrada anual de alunos levava a permanéncia maior em atividades de ensino, refletem-se na produção docente e em consequēncia no pouco preparo dos enfermeiros em outras atividades:

A proposta de uma rede básica de saúde ou sistemas locais de saúde, tendo por objetivo o melhoramento da assisténcia à saūde, não pode deixar que a investigação, um elemento crítico na estruturação dos servicos, fique limitada a uma elite de investigadores, mas sim a todos os responsáveis pela assisténcia. Essa democratização da pesquisa é importante para convertē-la em uma atividade de rotina, pelo menos em estudos mais voltados para a avaliação dos serviços e seus resultados ${ }^{118}$.

Contra a proposta se interpōem atē o momento as organizacōes dos serviços pesquisados e a formação dos enfermeiros. Entre os cursos de enfermagem no Paraná, onde se formaram a maioria dos enfermeiros entrevistados, duas escolas não ministravam disciplinas de iniciaçāo científica e, nas outras cinco, a carga curricular variava de 30 a 45 horas, 0 que é insuficiente para a execução de uma pesquisa, desde a elaboração do projeto, levantamento bibliográfico, coleta de dados e anālise.

Os municipios, por sua vez, não dispōe de recursos humanos suficientes para as atividades assistenciais, no nivel local e no nível central na ārea de enfermagem, que poderiam orientar esse processo. 
Com esse quadro segundo SOUZA e col..$^{119}$ o conhecimento adquirido pelos profissionais "é estātico, jā vem pronto, tem tamanho e significa que não se elaboram conhecimentos, não se constatam ou confrontam saberes, não se interroga o próprio conhecimento."

\subsubsection{Atividades extra-postos de saúde}

QUADRO 9 - Número e porcentagem de enfermeiros que declararam executar atividades extra-postos de saúde, em 22 municípios do Paranā, em 1988.

ATIVIDADES

Reuniões

Creches/Escolas

Coordenação

12

10,2

Comissões

12

10,2

CIMS/Conselhos

Cursos formação auxiliar

Escalas/Relatōrios

Levantamentos Estatisticos

Controle Material/Medicamentos

Curso de Especialização

Escola Auxiliar de Enfermagem

Outros*

Sem informação

*Outros: Vigiläncia Epidemiolögica, Direção de Departamento.

\subsubsection{Reuniōes externas}

A necessidade de comunicação com o nível central leva os enfermeiros a dispensarem, em reuniões com esse nịvel, uma alta proporção das suas horas em atividades fora do posto de saüde, para encaminharem assuntos relacionados com 0 desempenho de suas funcões administrativas e/ou reciclagem ou estudos.

Essa característica do trabalho em saúde püblica, as reuniōes externas, foi encontrada entre os médicos sanitaristas e enfermeiros 
nos centros de saúde de São Paulo. Para os primeiros, as reuniões externas tinham por finalidade discutir programas, normas, comparar experiéncias e tomar conhecimento de "pacotes" e, para os segundos, funcionavam como auto-controle e auto-supervisão profissiona $7^{56}$.

Nesse estudo, as reuniōes externas correspondem às características do enfermeiro e do médico sanitarista de São Paulo porque, apesar de grande proporção não ocupar o cargo de chefia, o exerce de fato, isto é, eram responsāveis por toda a organização tecnológica do processo de trabalho dos Postos de Saúde.

\subsubsection{Programas com creches e escolas}

Os enfermeiros de Curitiba eram responsáveis pelos programas de saúde em creches e escolas ${ }^{40}$.

No programa com as creches as atividades previstas eram controlar a vacinação, o crescimento e desenvolvimento das crianças, solucionando problemas simples e encaminhando os demais ao Centro de Saúde. 0 programa do escolar propunha-se a deteccão de problemas de acuidade visual, coluna, crescimento, fimose e criptorquidia, agendando consulta para escolares com alteração nestes exames e outros tipos de patologias.

As duas atividades eram exercidas dentro das escolas municipais da área de atuação. Uma das entrevistadas coordenava o trabaino em uma creche com 120 crianças e 4 escolas com 2.300 escolares.

"En creche a gente faz a parte educativa, com os pais, com as prōprias funcionārias da creche, fazemos treinamento também com os funcionários, com as babás e as cozinheiras, auxiliar de cozinha, e a parte de assistēncia direta também às crianças..."

"O programa de creche, nós atendemos uma creche dentro de G. (nome do bairro) fica aqui pertinho, então é feita uma visita semanal, e verificado principalmente pediculose e escabiose e nós também verificamos se não tem nenhuma criança com sintomas de doenças transmissiveis..."

"Ah, outra atividade extra-posto que se faz é o exame de glicemia nas escolas. Então temos um programa junto com o pessoal da Educação, se faz glicoteste em todas as crianças e se hā alguma anormalidade, a gente encaminha para o laboratório e passa prá consulta médica, se dá alterado, fazse isso nas escolas, onde realizamos também o parasitológico de fezes... todo o comeco de ano organizam os cursos para professores, sobre primeiros socorros básicos, que elas podem fazer na escolas - fornecemos também assim uma farmacinha básica..." 
0 trabalho da enfermagem nas creches e escolas, nos dias atuais, lembra os primórdios das enfermeiras escolares na Inglaterra e nos Estados Unidos.

Em $1892^{18}$, em Londres as primeiras enfermeiras distritais especializadas foram as escolares. Cada enfermeira era responsāvel por . 4 escolas e examinava diàriamente 100 crianças levadas pelos professores, uma por uma. Os principais problemas eram conjuntivite, doenças da pele, verminoses, e precariedade de higiene pessoal.

0 seu tratamento era prevenir e tratar as doenças mais simples e, nos casos mais sérịos, acompanhar o escolar até em casa e orientar os pais para procurar assisténcia médica.

Nos Estados Unidos, o trabalho de enfermagem nas escolas iniciou-se como suplementar ao dos médicos. A inspeção médica excluïa as as criancas das escolas, e estas ficavam brincando e perambulando pelas ruas. A situação era tão grave, em New York, que às vezes 300 crianças vagavam pelas ruas. Com a introdução da enfermeira na escola, esta começou a fazer tratamentos para escabiose, impetigo, eczema, etc. e as crianças, que anteriormente eram excluijdas, passaram a não sê-10 e eram tratadas precocemente $^{18}$.

Aigumas vezes essas enfermeiras sāo chamadas as primeiras enfermeiras de saüde püblica.

Como se vé, apesar de quase um século de distância, as nossas condições de saúde e de trabalho hoje são muito semelhantes as dos paìses desenvolvidosna época, quanto à forma como essa assisténcia é organizada, como quanto a concepcão "higienista e preventivista" do trabalho.

\subsubsection{Coordenaçāo em nível central}

Alguns enfermeiros, que eram responsāveis por postos de saūde, acumulavam funçōes de coordenação em nivel central e foram entrevistadas por desempenharem atividades no nivel local, fazendo parte dos 117 enfermeiros, que compuseram a população estudada. Vale ressaltar que poucos municipios dispunham de enfermeiros, exercendo exclusivamente atividades de enfermagemnonivel central: Curitiba, Araucäria, Cambēe Londrina.

"Na divisāo a gente faz o que chamam de planejamento, mas de certa forma acaba nāo acontecendo, planejamos o trabalho que por vontade ocorra... o horário médico passou a ser uma atividade nossa, formular, por, repor e tentar discutir com o diretor da autarquia de saúde necessidade de admitir mais profissionais."

"Sou coordenadora do serviço de saúde no municīpio." 


\subsubsection{Participacão em comissōes dos serviços}

As comissões estavam envolvidas com atualização de rotinas, confeccão de manual e divulgação do trabalho realizado pelo município atravēs de uma novela.

"Comissāo de esterilizaçāo, da rede de frio e imunizacão". (elaboracão de rotinas sobre esses temas).

"A gente divulga o trabalho da Instituicão através de uma novela."

\subsubsection{Participação em Comissōes Intermunicipal de Saúde e Conselhos Co- munitários}

A participação em instāncias deliberativas era de 2 enfermeiras: uma na Comissão Institucional Municipal de Saúde (CIMS), como presidente e em outra era representante do municipio na Comissão Regional Institucional de Saúde (CRIS).

Os outros 4 participavam apenas das reuniões, informalmente como assessoria técnica e secretāria.

"A gente tem a CIMS, só que não fazemos parte, mas participamos das reuniōes, inclusive fazemos atas. Eu participo informalmente da Assessoria técnica..."

Foram excluīdos da categorização como participantes do conselho comunitário os depoimentos que só relacionaram reuniões com liderancas e/ou associação de moradores. Em um dos municipios essa atividade era de responsabilidade das chefias de posto. Apenas 2 profissionais afirmaram estar formando um conselho comunitário.

\subsubsection{Elaboracāo de escalas, relatōrio, levantamentos estatísticos e} controle de material/medicamentos

Os poucos profissionais disponiveis em nivel central levam os enfermeiros, em alguns municipios, a realizarem atividades nesse nivel ou por solicitacão da chefia imediata, caso também das comissōes ou por optarem, como em dois municipios por não terem um único chefe do serviço de enfermagem, dividindo as tarefas entre todos os enfermeiros ou tendo chefia única, em sistema de rodizio semanal. 
4.4.5.7. Cursos de formaçao de auxiliares de saúde e escola de auxiliares de enfermagem

A formação do auxiliar de saüde é assumida pelos serviços, tendo em vista que a expansão da rede não encontrou ocupacionais treinados no mercado. Os cursos de formação têm duração de 3 meses e durante o período de aulas teöricas, em geral um més, os enfermeiros estão fora do posto de saúde, retornando a ele para acompanhar o estágio supervisionado.

A lei do exercício profissional no 7498/86 vedou a formacão de atendentes, extinguindo a categoria, que teria, a partir desta data, dez anos para a sua transformaçăo em auxiliares de enfermagem por meio de cursos regulares ou exames de supléncia 19 .

Os municīpios, seja por inviabilidade polītica (não tendo interesse na capacitação e qualificação dos profissionais) seja por inviabilidade técnica (não dispor de pessoal treinado para contratar nas substituiçōes ou por expansāo da rede) deixam de cumprir a lei e incorporam em seus quadros pessoal não treinado com o aval dos enfermeiros.

É muito difícil para o profissional, muitas vezes isolado, com um mercado de trabalho restrito, às vezes, o único existente no municipio, contrariar a vontade do dirigente e impedir essas contrataçōes. Por outro lado, a população que è atendida pelo pessoal auxiliar, com menor qualificação, passará a não ter nem esse atendente.

Em dois municipios, os enfermeiros tinham parte de sua carga horária contratual dedicada ao ensino e/ou coordenação do curso de auxiliares de enfermagem, mantido pela municipalidade.

\subsubsection{Clima Organizacional}

O clima organizacional foi avaliado por fatores intrainstitucionais que facilitavam ou dificultavam o desempenho. 


\subsubsection{Fatores facilitadores do desempenho}

TABELA 11 - Nümero e porcentagem de enfermeiros segundo a existência de fatores institucionais que facilitam o desempenho, em 22 municīịos do Paraná, 1988.

\begin{tabular}{lcc}
\hline \hline EXISTËNCIA DE FATORES FACILITADORES & No & $\%$ \\
\hline Sim & 66 & 56,4 \\
Não & 33 & 28,2 \\
Sem informação & 18 & 15,4 \\
\hline T O T A L & 117 & 100,0 \\
\hline \hline
\end{tabular}

Mais da metade dos enfermeiros responderam afirmativamente sobre a existência de fatores institucionais, que facilitavam o seu desempenho.

0 alto percentual de nāo informantes se deve à forma como a questão foi formulada, pois quando o entrevistado titubeava em responder, passava-se para a questão seguinte: existência de fatores que dificultavam e por falha não se voltou a reformular a questão. Tal falha só foi constatada por ocasião da tabulação dos dados levantados.

QUADRO IO - Nümero e porcentagem de fatores intra institucionais facilitadores do desempenho relacionados pelos enfermeiros, em 22 municīios do Paraná, 1988.

\begin{tabular}{lrr}
\hline FATORES FACILITADORES & No & $\%$ \\
\hline Bom relacionamento inter-equipe & 22 & 33,3 \\
Apoio Institucional & 21 & 31,8 \\
Autonomia profissional & 12 & 10,2 \\
Diretrizes politicas & 9 & 7,6 \\
Auxilio Transporte & 5 & 4,2 \\
Integracão com outros níveis & 4 & 3,4 \\
Apoio da Supervisão & 4 & 2,5 \\
Recursos Humanos qualificados & 3 & 2,5 \\
Aceitacão do trabalho pela Comunidade & 2 & 1,7 \\
Recursos Humanos Suficientes & 2 & 1,7 \\
Demanda Adequada & 2 & 0,8 \\
Trabalho Gratificante & 1 & 0,8 \\
Outros* & 4 & 3,4 \\
Sem informação & 17 & 14,5 \\
\hline
\end{tabular}

Outros*: amor à camisa, grupo jovem, disponibilidade de recursos materiais

Os fatores citados como facilitadores do desempenho podem ser classificados entre os que trazem satisfação no trabalho, estudados por diversos autores $14,16,27$. 
Entre os que responderam afirmativamente à questão sobre a existēncia de fatores que facilitassem 0 seu desempenho $(56,4 \%)$, o bom relacionamento inter-equipe foi o mais citado:

"... o que facilita aqui é que existe uma uniāo muito boa, então a equipe se entrosa muito bem, acho que isso é muito importante, porque vocé trabalha:"

0 bom relacionamento inter-equipe è importante para se obter maior eficiēncia e satisfação no trabalho.

No Brasil ${ }^{35}$, em 1983, os enfermeiros de estabelecimentos de saúde (hospitalares e para-hospitalares) o consideraram o segundo fator, em uma lista em que a existéncia de creches para funcionärios obteve o percentual mais alto.

\subsubsection{Apoio institucional}

Sob essa denominação foi enquadrada uma ampla gama de depoimentos.

"... a gente encontra facilidade no desenvolvimento de qualquer coisa que vocé queira instituir em programas, vocé recebe apoio."

"Acho que a própria administraçao, digamos o fato de termos enfermeira, diretora do departamento profissional de enfermagem, ajuda bastante."

"... facilidade a gente tem, facilidade em relacão à chefia atualmente, temos como chegar para a chefia, conversar com ela, discutir problemas."

\subsubsection{Autonomia}

A Ordem das Enfermeiras e Enfermeiros do Quebec (0.I.I. Q.) entende a autonomia como a "capacidade que tem o homem de ser integralmente, de dar um sentido a sua vida e de em função disso, escolher o conjunto de suas ações por uma direção pessoal que se orienta para a completa realização de si mesmo."

0 exercicio profissional de forma autónoma não só leva a satisfação no trabalho como uma melhoria da auto imagem ${ }^{24}$.

Desse estudo, os enfermeiros entrevistados consideravam como autonomia a liberdade de realizar atividades de enfermagem, pois 'não tinham um controle sobre o seu trabalho, quer porque não eram supervisiona- 
das por outros enfermeiros, quer porque não existiam programas e atribuicōes para serem seguidos, conforme o encontrado em $2 / 3$ dos municipios pesquisadas (Tabela no 1 ).

por ROCHA 107 que assinala um trabalho rotineiro e portanto com pouca autonomia entre os enfermeiros da Secretaria Estadual de São Paulo, pelo seguimento de programas e atribuições normatizadas, permitindo que até 0 treinamento do pessoal auxiliar prescinda desse profissional.

"A gente tem de ter autonomia de fazer determinada coisa, por exemplo: a questāo de horário, que determinamos, nāo é uma coisa muito rigorosa, para poder participar tambēm na parte de planejamento, coordenaçāo, essa coisa que é interessante."

"Bom, o que facilita aqui é que a prefeitura dá liberdade total..."

"0 que facilita é uma certa autonomia que se tem de trabalhar assim em enfermagem. A gente planeja e toca o serviço."

"Existe uma certa autonomia pra gente discutir algumas questões que são especīificas de enfermagem, então acho que isso facilita um pouco as coisas..."

"Eu acho que a própria liberdade de acão facilita muito. Vocé vé a gente estā solto, nāo tem ninguém pegando no pé."

"Autonomia que eles nos dāo. Vocé faz o que for preciso, o Posto è sua responsabilidade, crie, faca o que quiser..."

Essa autonomia nāo é dada pelo poder de decidir na programação ou pelo modo mais amplo que é o poder administrativo dos que detém os recursos financeiros 105 .

Para GORZ ${ }^{57}$ aquele que faz o projeto, o analista das cadeias de produção, o técnico que verifica, os que destacam os postos de comandos sobre os outros, distinguem-se principalmente pela liberdade face ao próprio trabalho e pelo poder exercido por meio desse trabalho (critério fundamental para definir essa camada). A empresa capitalista assume cada vez mais o aspecto de uma máquina complexa, onde o conteúdo do trabaTho e as relações de trabalho com os objetos e as pessoas não são mais determinadas, cada dia, por um ato de comando hierárquico, mas sim fixados, objetivamente de uma vez por todas, pelas normas e estrutura da empresa. os técnicos sentem-se autónomos, porque no seu ofício não recebem ordens do patrāo. 
4.4.6.4. Auxīio transporte, integração com outros niveis, apoio da supervisāo, recursos humanos qualificados, aceitação da comunidade, recursos humanos suficientes, demanda adequada a oferta, trabalho gratificante

0 transporte disponivel, a integração com outros serviços nos casos de encaminhamento a outros órgãos do município, recursos humanos em quantidade satisfatória e capacitados são recompensas extrínsecas, bem como o apoio dado pela supervisão. A aceitação pela comunidade e o trabalho gratificante podem ser considerados recompensas intrinsecas, como as descritas por BONJEAN e col. ${ }^{16}$.

MOTTAZ ${ }^{88}$ em seu estudo "encontrou que os maiores determinantes de satisfação no trabalho foram assisténcia do supervisor, tarefas gratificantes, autonomia e salärio. Os،resulẗados são semelhantes aos fatores facilitadores dessa pesquisa: autonomia, e. apoio institucional.

\subsubsection{Fatores dificultantes do desempenho}

TABELA 12 - Número e porcentagem de enfermeiros segundo a existéncia de fatores institucionais que dificultam o desempenho, em 22 municipios, Paranā, 1988.

\begin{tabular}{crr}
\hline \hline FATORES DIFICULTADORES & № & $\%$ \\
\hline Sim & 112 & 95,7 \\
Não & 3 & 2,6 \\
Sem informação & 2 & 1,7 \\
\hline T O T A L & 117 & 100,0 \\
\hline \hline
\end{tabular}

Um alto percentual de entrevistados identificou fatores que dificultaram o seu desempenho, sugerindo que a prätica era desenvolvida em condições não favoráveis.

Na sociedade americana, trabalho de investigação mostra que o nivel de satisfação no emprego, geralmente aumenta dos blue-collors (operärios) para ocupaçōes profissionais. Já enfermeiros tem um nível baixo de satisfação em relação a outras ocupações, superando apenas os agentes policiais, capatazes e operários de fábrica, que apresentavam menor nivel de satisfação que eles 88 .

A forca de trabalho nos municipios pesquisados aumentou de $12,8 \%$ em 1987 (época do projeto) para 1988 (no periodo da coleta dos dados). Mas se persistiremas condições atuais em relação aos fatores extrinsecos ein- 
trinsecos de satisfação no trabalho e de evasão dos cursos de enfermagem nas faculdades públicas, possivelmente poderemos estar num futuro próximo, enfrentando o problema mundial de falta de mão de obra qualificada.

QUADRO 11 - Nümero e porcentagem de fatores intra institucionais dificultadores do desempenho relacionados pelos enfermeiros, em 22 municīpios do Paranā, 1988.

\begin{tabular}{|c|c|c|}
\hline FATORES DIFICULTANTES & № & $\%$ \\
\hline Planta física inadequada & 52 & 46,4 \\
\hline Insuficiēncia de Recursos Humanos & 41 & 36,6 \\
\hline Capacitação Insuficiente de Recursos Humanos & 31 & 27,6 \\
\hline Falta de Medicamentos & 25 & 22,3 \\
\hline Falta de transporte & 16 & 14,2 \\
\hline Falta de Material & 14 & 12,5 \\
\hline Baixo salärio & 14 & 12,5 \\
\hline Relacionamento inter-equipe & 13 & 11,6 \\
\hline Falta de autonomia & 10 & 8,9 \\
\hline Ingerēncias Politicas & 10 & 8,9 \\
\hline Integração & 9 & 8,0 \\
\hline Pouca valorização do trabalho & 9 & 8,0 \\
\hline Diretrizes da Instituição & 9 & 8,0 \\
\hline Carga horāria Insuficiente & 8 & 7,1 \\
\hline Centralização & 7 & 6,2 \\
\hline Falta de apoio & 7 & 6,2 \\
\hline Insuficiēncia de verbas & 5 & 4,4 \\
\hline Supervisão inadequada & 5 & 4,4 \\
\hline Ausēncia de Divisão de Enfermagem & 5 & 4,4 \\
\hline Indefinição de funçöes & 5 & 4,4 \\
\hline Atividades Administrativas Excèssivas & 5 & 4,4 \\
\hline Equipamentos inadequados & 4 & 3,5 \\
\hline Comunicação & 3 & 2,6 \\
\hline Motivação & 3 & 2,6 \\
\hline Situaçāo do País & 2 & $1 ; 7$ \\
\hline Outros & 15 & 13,4 \\
\hline Sem informação & 1 & 0,8 \\
\hline
\end{tabular}

Essa questão, ao ser formulada no pré teste, revelou-se de difícil compreensão pelos entrevistados. A experiéncia no seü próprio trabalho e dificuldades relatadas por ex-alunos, em municipios da região, le- 
varam a autora deste trabalho estimular as respostas, perguntando sobre problemas quanto planta física, recursos humanos, material e encaminhamentos.

As respostas espontāneas e estimuladas foram tabuladas em conjunto, o que pode ter levado a uma distorcão, quanto às frequéncias em que foram citadas, como por exemplo, a questão salarial não ter tido um maior percentual entre os pesquisados. Por se ter uma grande variedade de respostas serão analisados os mais frequentes.

\section{4:4.7.1. Deficiencia de planta física}

Não sendo mais uma organização centralizada, como os postos construīdos pelo governo estadual, cada municipio tem estruturado seus postos de diferentes formas, que vão desde novas construções atē casas adaptadas. Com isso os espaços se tornam insuficientes para atender à demanda da clientela, para garantir sua privacidade ou para respeitar as normas técnicas nas āreas de curativos e esterilização.

"Principalmente este é o tipo do Posto que tem que passar um trator por cima, derrubar tudo..."

"Eu tenho uma única sala onde se faz pré, pós, patologias, só não faz vacina porque o Centro de saüde é aqui do lado..."

"Os postos da ārea rural têm uma planta física terrível. Um è novo, mas dois são adaptados mesmo. Uma casa, que não veda nada: vocé está falando aqui e está se escutando ali fora. A estrutura. vocé tem uma sala num lugar que não devia ter, inclusive até em termos de pintura é precária, não te dá ánimo e não dá ãnimo nos prōprios funcionārios. A gente vê tanta coisa fora do lugar, que desanima bastante, è desestimulante."

"... prā nōs fazermos grupos de gestantes e de hipertensos, não tem uma sala exclusiva. Geralmente nós usamos o consultório médico, mas o consultório médico é pequeno, prá caber 15 ou 10 pessoas ali. $\bar{E}$ um sufoco, num calor desses!"

... "você nāo tem um ambiente de trabalho que facilite bom desenvolvimento, porque vocé trabalha sem ventilador. Só tem um no posto, geralmente vai prá sala do médico. Os auxiliares tambēm precisam (ventilador). Muitos postos nāo tém geladeira ainda (municīpio da região Norte do Estado que apresenta alta temperaturas, a geladeira a que se refere è para os funcionärios).

"... jamais eu posso fazer consulta de enfermagem no dia que tem médico, porque nāo tem sala. Fica difīcil trabalhar assim." 
"... voce viu onde está fazendo a consulta de enfermagem? E na mesma sala de triagem, de curativos, de tudo."

"... apenas a questão de ser um antigo posto. É muito pequeno, vocé tem que improvisar. Por exemplo, pra trabalhar com grupos vocé pede uma sala emprestada para a escola."

Não é privilégio dos postos municipais não ter locais reservados ao trabalho da enfermeira.

Ao observar as atividades de pós consulta e atendimento de enfermagem de Centros de Saúde, da Secretaria de Estado de Saúde de São Paulo, GONCALVES ${ }^{58}$, em relação ao local onde são executadas, as descreve da seguinte forma: "essas são praticamente desenvolvidas em püblico, pois a regra $\bar{e}$ de utilização de uma sala pequena, geralmente abarrotada de mesas, cadeiras, armärios e balanças - nāo se imagine que haja quantidade suficiente de mōveis nos centros de saüde, pois eles são poucos e velhos; - que não hā é espaço suficiente para pō-los - em que dois ou três profissionais trabalham ao mesmo tempo, com as portas abertas para a circulação dos clientes, com mais duas ou três mäes, as duas ou três crianças atendidas $e$ as vezes seus irmãos. Pelas portas entra o ruỉdo dos corredores $e$ salas de espera, de tal modo que a impressão geral, atordoante, $\bar{e}$ a de um campo de batalha... Seria fantasia imaginar que, nessas condicōes de tralho, qualquer projeto sério e consequente pudesse ser implantado, muito menos o projeto, que atribui a essas atividades a finalidade geral de orientar...

Desde o caso mais simples ate o mais complexo, atividades que presumem o estabelecimento de uma relação interpessoal no trabalho. Nada disso é possīvel nas condiçōes caōticas, em que sé desenvolve o trabalho de enfermagem; o que se procura fazer, resultarā em arremedo de orientação, mesmo quando houver maior empenho em consegui-la."

\subsubsection{Insuficiência de recursos humanos}

Os recursos humanos são insuficientes na ärea de enfermagem $_{j} 0$ que pode bem ser avaliados pelas tabelas no 9 e no 10 , que mostram o número dos enfermeiros em relacão aos postos e aos auxiliáres de saúde.

os enfermeiros reconhecem essa escassez, que ē mais aguda em alguns locais com alta demanda.

Tambëm são fatores, que dificultam o desempenho, 0 pequeno número de auxiliares em relação aos postos, a auséncia de médicos das grandes especialidaries, como ginecol'ogista e de serviçais (zelador e jardineiro). 
"É o fato de termos um número pequeno de auxiliares de saúde para volume de tarefas que tem."

"... nōs temos 14 unidades de saüde, porēm sō temos quatro enfermeiras, entāo dificulta bastante, pra se dar uma assistência da forma que a gente acha que é certa e que nös realmente queremos prestar pro paciente."

"... recursos humanos, a gente sempre trabalhou com bastante dificuldade e há um rodīzio muito grande de auxiliar e com isso nāo fixa o pessoal. E isso dificulta a relacão com o paciente e mesmo com o próprio auxiliar, que se desloca para muito longe. Isso ai gera um ambiente tenso dentro do trabalho."

"... vocē tendo uma Unidade de Saūde, um só funcionärio trabalhando, ou dois, dependendo da demanda ali do local, vai ser quase impossível poder desenvolver um programa, de trabalhar com a comunidade, fazer visita. É utópico pensar que o funcionário farā isso, dependendo da Unidade $\bar{e}$ um só funcionário."

"- Como é que vocè faz nas férias? (entrevistador)

- Nas férias nós temos geralmente agente de saüde que nōs chamamos de "coringa", ele tenta cobrir as férias dos outros, mas isso nem sempre acontece."

"Eu acho que o que dificulta muito o desempenho das atividades è a questão da gente não ter o número suficiente de profissionais e não poder contar com isso... E nāo ter postura que o secretärio tem. Então na conversa que se tem, a gente consegue perceber bem aquele conceito de que 0 enfermeiro não è necessārio..."

"... porque ele tem aquele conceito de que um enfermeiro consegue tocar tudo, ele é mujto importante a nīvel de estruturar um posto novo e na hora que ele estā funcionando nāo precisa mais."

"Solicitasse a contratacão mīnima de pessoal que trabalha, zelador que vocé não tem na Unidade. 0 serviço de jardinagem é do agente de saúde, capina a frente do Posto, ten coisa assim do arco da velha aqui."

"Como tem poucas enfermeiras, temos que assumir trēs, quatro postos de umà vez, então você não consegue fazer uma supervisão assim... pra você é insatisfatória."

\subsubsection{Capacitação insuficiente}

A forca de trabalho no Brasil em enfermagem é composta por enfermeiros, na proporcão de $8,5 \%$. Os serviços municipais de saüde pes- 
quisados nāo sāo exceçāo à essa regra, apresentando uma proporcão de enfermeiro de $11,9 \%$. 0 treinamento, quando não realizado em curto perīodo de tempo, (Londrina e Cambé - onde o curso tem duração de 3 meses) o é em serviço, de forma nāo planejada e com a supervisão dos próprios auxiliares mais antigos. Os métodos utilizados não são os adequados, como os sugeridos pelo treinamento em larga escala 119 .

A própria capacitação do enfermeiro, entre os pesquisados na ārea de Saúde Püblica, quer seja a habilitação quer seja a especializacão, apresenta baixo percentual, conforme os resultados mostrados pelas tabelas no 4 e 5 .

Em um municipio, dois enfermeiros referiram como fator que interfere no desempenho o fato do secretārio nāo ter formaçāo técnica apropriada.

"... é o prōprio grau de instrução, porque quando foi contratado como agente de saūde, nāo foi exigido o 20 grau, só o 10 grau..."

"Muitas vezes é insuficiente o nivel de escolaridade dos atendentes, elas são contratadas a sopetão, e a polītica que contrata elas. Então, lar gam a vassoura e vão trabalhar na enfermagem. Chegam ali, vocé tem que ensinar até ver temperatura prā uma pessoa e muitas delas não sabem ler..."

"Uma coisa que vocé pensa, que o funcionário é muito bom, só porque ele trabalha há três anos, vocé vai ver que não é, não é, não sabe, então o nivel deles que está dificultando bastante. Eu inclusive me enganei com uma funcionária. Vocé pensa que é muito boa e de repente nāo é aquilo. Então até dá medo, porque ela tem uma autonomia: lá no Distrito (rural) é ela - então é o médico da cidade - isso assusta um pouco, o posto lá é o único que tem."

"Kas o trabalho fica difícil, porque eu não fiz especialização em saúde püblica. Eu saī da escola e vim trabalhar..."

"Inclusive a minha experiéncia é pequena e isso às vezes dificulta muito, até pelo prōprio fato de nāo ter acesso aqui a uma habilitação."

"Talvez a própria cabeça do pessoal. Eu acho que os enfermeiros daqui tem um bom nīvel, mas é mais na parte técnica. Eu acho que a visāo de saúde püblica está muito pálida.. e a prōpria visão dos médicos daqui."

"Depois tem a parte de funcionamento mesmo, de auxiliar, pois os mais antigos entraram por indicação polītica. Não executam as coisas direito, levam tudo do jeito que dā, improvisam, inutilizam as técnicas corretas. A gente tem encontrado muitas dificuldades." 
4.4.7.4. Falta de medicamentos, material e insuficiēncia de verbas

A impropriedade das prioridades das politicas nacionais na àrea da saūde tem o seu reflexo na àrea municipal.

A politica expansionista da rede de postos dos municipios em detrimento da qualidade, a pouca experiéncia de muitos profissionais em programação e planejamento, as demandas aumentadas pelo agravamento das condições de vida, a escassez de recursos financeiros levam a permanentes crises nos recursos materiais e na manutenção, dificultando o trabalho e, em consequéncia, o atendimento da população.

os municipios, que incluem em suas atividades, 0 atendimento às doenças mais comuns e frequentes na rede, necessitam desses medicamentos porque ao auxiliar não compete fornecer receitas, mas sim utilizar-se de medicamentos padronizados. Sem contar-se com as caracteristicas da clientela que, se não dispuser da medicação, não tem poder aquisitivo para comprà-1a.

Apenas $11 \%$ do total do mercado público $(36,1 \%)$ circula atra vēs da CEME com trezentos e setenta e oito färmacos ${ }^{64}$.

"Tem época que falta medicamentos, principalmente este medicamento básico, este que a gente mais usa, às vezes, vocè fica assim 15 dias sem AAS."

"0 que estā dificultando hoje o nosso trabalho? Seria basicamente a falta de medicamentos, nós estamos enfrentando uma crise séria de medicamentos, o nosso grupo de hipertensos está morrendo, porque não tem medicamento, entāo essa instabilidade. Hoje tem medicamentos, o més que vem nāo tem, não é uma coisa certa, todo mês. Isso está dificultando o nosso trabalho, nāo sō medicamentos, como o material, de repente estā faltando gaze para fazer curativos..."

\subsubsection{Falta de transporte}

0 transporte è necessário nāo sō para deslocamento da equipe em postos da zona rural (enfermeiros, médico, auxiliares de saúde) como também para atender às emergéncias e suprir de material ou transportar material, para exames laboratoriais a serem realizados em nivel central.

A existência de transporte para o trabalho de enfermagem nas comunidades é considerado como de muita importāncia para eficiéncia e satisfacão no trabalho por $85,8 \%$ dos enfermeiros nos estabelecimentos de saüde, no Brásil, em $1983^{35}$. 
0 salärio foi considerado como fator interferindo no desemprego por apenas $11,9 \%$ dos entrevistados. As razōes podem estar relacionadas à forma como a questão foi formulada, já discutida anteriormente e ao fato de que nessa época os servicos municipais de alguns municipios tinham salärios semelhantes, senão superiores, aos pagos na área hospitalar. A proposta neo-liberal do governo eleito em marco de 1990 e toda a campanha empreendida contra o funcionalismo público pode ter levado a reverter esse quadro e uma nova pesquisa poderá apresentar dados totalmente diferentes, em relação a essa variạvel, podendo colocá-la não mais em 70 lugar, mas como um dos primeiros fatores de insatisfacão.

Os auxiliares de saüde, que executam a maioria das ações com baixos salärios, descontentes, impedem que o enfermeiro exija o maior empenho, caindo no malfadado cỉrculo tão conhecido da administração pública: baixos salários-insatisfação-baixa produtividade-ineficiēncia-turnover.

"... entāo vem o problema da compensaçāo salarial-vira e mexe em reuniāo a discussāo é essa, un dos maiores problemas è esse. A gente teve um aumento em marco, que foi um aumento grande, mas o que aconteceu? Toda a Prefeitura trabalha 6 horas e nós passamos a trabalhar 8 horas; teve aumento salarial mas teve aumento da jornada também."

"O que mais que dificulta? 0 salärio, o salärio é muito baixo. De repente eu até questiono porque é que vocè está lá tanto tempo. Quer dizer tem o seu lado profissional que vocè nāo vai deixar cair, vocè é profissional, mas que o salärio interfere bastante, interfere. De repente, uma agente de saúde ganhando Cz $\$ \mathbf{3 . 0 0 0 , 0 0}$ (Cruzados) você vai cobrar como? Quer dizer, esta questāo polītica, essa questāo salārio acho barra muito pesada. Daī vem a questão de administração mesmo, que é medicamento que falta, è transporte que nāo tem..."

"Uma dificuldade grande é o salärio. Isso aì vai gerar um descontentamento do próprio auxiliar de saúde, acho que acaba sendo primordial, a lèm do empenho que ele tenha com o que ele faz. 0 salärio influencia bastante, vocē nāo tem muito que exigir, vem sofrendo crises. Quando entrei há dois meses atrás, eles estavam numa crise de salário, você não tinha como chegar, tudo partia dāi, "Como é que vou fazer isso, se não tenho salário." 
4.4.7.7. Falta de autonomia e centralizacáo

Os dois fatores podem ser analisados conjuntamente. A autonomia não é exercida,porque algumas atividades, consideradas como de sua competēncia, não são executadas, porque esbarram em chefias que impedem essas açōes. A centralização também é referida por alguns profissionais, que ao desenvolverem projetos, estes não são viabilizados por contrariarem as propostas politicas de secretários ou de prefeitos. 0 planejamento situacional na ārea da Saúde de MATUS e o pensamento estratégico de TESTA apud RIVERA $^{105}$, por serem propostas recentes, não são do conhecimento desses profissionais, que em sua maioria tem uma visão ingénua, baseada em argumentos técnicos, para contrapor aos politicos que utilizam a saúde para ações populistas e demagógicas.

"... ela (Secretāria) não sabe ao certo o que faz uma enfermeira. gente mostra, mas ela corta, tira autonomia; tudo que a gente vai fazer tem que passar por ela. Vocé sabe que uma coisa é imprescindível, importante, ela nāo tem essa visāo, ela tem a visāo de agradar o prefeito. A gente faz um planejamento bonitinho, a gente trabalha muito junto, chega 1á, ela corta. Assim coisas pequenas, porque não contentou Fulano, Beltrano que é vereador, que não sei o que lá... então se se tivesse mais autonomia..."

"... tudo que vocé vai decidir precisa pedir. Entāo è muita falta de autonomia."

"E tem também a questão do secretário mesmo, ser muito autoritário. A gente tem a divisāo, tem que ser respeitada nossa opiniāo, tudo, mas sempre acaba sendo a opiniāo dele, que prevalece mesmo."

\subsubsection{Ingerēncias polīticas}

A municipalização na àrea da saūde desloca um poder, até então da área estadual para o nível local. Essa proximidade e o mau uso com fins politico-partidärios da utilização de cargos interferem no trabaTho, quando os profissionais e ocupacionais contratados são indicados ou demitidos, não levando em consideração a sua competēncia técnica. No período pesquisado não era exigido concurso público para o provimento de cargos.

"Tem muita polītica, porque vocē tem agentes que nāo desempenham bem, : são indicados politicamente, que vocē nïo pode ter ou não pode escolher.".

"Vocé é coordenadora do posto, mas ao mesmo tempo nāo è, por questāo 
polītica. Entāo de repente vocè quer de uma maneira, mas vocé sabe que, lá em cima, eles de outra... então vocé nunca consegue fazer nada. De repente vocè só tem o cargo de coordenadora do Posto, mas na realidade vocé não e.".

Os fatores facilitadores relacionados a recompensas externas e internas, como a outra face da moeda, aparecem como dificultadores, acrescido de outros.

Em 1983, o estudo COFEN/ABEN ${ }^{24}$ mostra que as secretarias municipais relacionaram entre problemas que afetavam a implantação de programas: a infra-estrutura deficiente $(87,5 \%)$, questōes financeiras $(81,2 \%)$ e recursos humanos $(75,0 \%)$.

Apesar de controvérsias entre os fatores mais importantes, se os externos (salário, condicões de trabalhó) ou os internos como autonomia e responsabilidade, tanto um como outro interferem na qualidade da assistēncia prestada 88 .

A origem da maioria das dificuldades encontradas nos servicos de saúde está na pouca prioridade dada ao social pelo estado brasileiro, em seus trēs niveis (Federal, Estadual, Municipal) durante muitos anos com poucos recursos financeiros. Algumas acōes administrativas poderiam ser feitas pelos servicos municipais; para eliminar alguns fatores e melhorar a satisfação dos profissionais, tais como: acessibilidade aos administradores, participação na tomada de decisões, descentralização da autoridade, cursos de aperfeicoamento, reconhecimento do valor do trabalho e outras técnicas desenvolvidas pelos administradores ${ }^{16,62}$.

\subsubsection{Participação na programação}

TABELA 13 - Nümero e porcentagem de participação de enfermeiros na programação das atividades de saüde, em 22 municípios do Paraná, 1988.

\begin{tabular}{lrr}
\hline \hline PARTICIPACÃO NA PROGRAMACÃO & No & $\%$ \\
\hline Sim & 51 & 43,6 \\
Não & 34 & 29,1 \\
Parcialmente & 27 & 23,1 \\
Sem Informaçāo & 5 & 4,3 \\
\hline T O T A L & 117 & 100,0 \\
\hline
\end{tabular}


participar da programação das atividades de saúde. A questão teve que ser explicada algumas vezes, pois os entrevistados, quando questionados se participavam na programação das atividades da instituição, tinham dificuldades em entendè-la. Esse fato era, sem dúvida, reflexo da ausência de programaçāo em vārios municīpios, descritos na tabela no 1 e a falta de participação nessas atividades.

RIVERA ${ }^{105}$, ao discutir a programação local, afirma que esta deve "comportar um movimento de descentralização do aparelho institucional, que garanta a participação efetiva da população no planejamento". Pretendendo-se que a população participe desse processo, como justificar que quase $30 \%$ dos enfermeiros responderam negativamente à questão?

Se a administração excluia participação dos técnicos, como pretende que a mesma seja construīda com a população?

Os sistemas de planejamento e de programação deveriam estar regidos pelas premissas básicas do planejamento estratégico, que são a inseparabilidade entre planejamento, programação e gerência e busca da viabilidade, atravēs da anālise dos atores e seus projetos ${ }^{105}$.

Os que responderam afirmativamente, participavam das reuniões, na elaboração de normas, projetos de municipalização. Programação e Orçamentação Integrada (POI), dependendo do seu grau de envolvimento com o nivel central), e do fato de ser chefe de postos e coordenadores de departamento.

"Posso dizer por mim, não sei o enfermeiro como um todo. Eu sempre participei na elaboração dos manuais, sempre fui chamada para participar das reuniões, para participar na elaboracāo de normas, de experiências e tal... posso dizer na gestāo passada, nessa gestāo nós tivemos participação em termos de treinamento de atendentes..."

"Quase 100\% participei da POI, municipalizacāo (projeto de municipalização solicitado pelo governo estadual para repasse de verbas)."

"Eu participo sō através da CIMS, porque eu sou secretāria da CIMS. Não tenho autonomia prá isso, chegar atē o pessoal da polītica."

"... estamos tentando programar através da avaliação de hoje com a população, já temos uma programação determinada para o ano que vem. $\bar{E} \quad 0$ que se pretende deste ano, sendo uma idéia que jā foi levada ao nỉvel central, é tentar fazer um planejamento em cima de prioridades. Como existe tudo para se fazer, e nāo dā para se fazer tudo de uma só vez, entāo tentar trabalhar o diagnóstico de saúde local." (o único depoimento que fala em diagnöstico de saúde).

Os que tiveram us seus depoimentos enquadrados como uma 
participaçāo parcial, consideravam que contribuiram em algumas instāncias de deliberacão como, por exemplo, a divisāo de enfermagem ou nas decisões internas com a equipe ou ainda de forma esporádica ou eventual, no caso dos projetos de municipalização ou comissões.

"Borm, a gente nem fica sabendo qual a programaçāo geral da Secretaria. Agora da Divisão, foi feito planejamento, no ano anterior. Programouse, mas viu-se que depois surgiram tantas prioridades, nāo deu pra ser feito nada então, sempre tem aquelas eventualidades que não dá mesmo..."

"A gente programa mais a nível local."

"... muito pequena a participaçāo em nīvel central. A gente fica sabendo quandó estā feito, mas nāo é informado antes. A participação vem de comissōes, às vezes escolhida. Ma participacāo geral, a gente fica meio sem saber."

"0lha, eu participei da programaçāo, da elaboração do projeto de municipalizaçāo, porque è a única forma que a gente tinha de ter acesso a alguma informação do que estava acontecendo, só por isso, porque eu avalio a minha participacão, e também de outros profissionais, a nīvel de interferéncia de estar programando alguma coisa, de estar pensando ou fazendo um diagnóstico, nāo existe, entāo ela é zero. Mesmo a nīvel de posto, esta semana eu vou discutir isso, vamos fazer uma reunião, ñão sei das quantas, vamos ter que discutir isso de emergēncia... Na verdade vocé apaga incéndios, você tem autonomia prā apagar incēndio, nāo pra planejar."

0 percentual dos que responderam negativamente,

consideraram nula a sua participação ou, mesmo quando solicitada, havia interferēncia de níveis hierärquicos superiores.

"Nula, zero, nada, mera executora de tarefas, mais nada. Só executo, nāo sei porque. Só cumpro ordens, infelizmente."

"Zero à esquerda. 01ha, eu ainda participo de algumas coisas, porque é meu jeito, e eu sou metida. Ninguém pergunta o meu palpite, mas eu vou là e dou."

"Nāo tenho participação nenhuma. Só prā vocē ver uma coisa, até na CIMS, o pessoal nāo sabe o que acontece, nem a chefia de divisão sabe. Isso, acho que atē que repete aquilo que eu te coloquei na característica aī da administração."

"Eu realmente nāo tenho voz. Nāo adianta eu dizer que estou precisando disso ou daquilo, prā melhorar naquilo, porque realmente não sou ouvida." 
"... eu estou aqui há nove meses, atē agora ninguém me pediu opiniāo nenhuma. Eu acho que nāo existe participaçāo, que as coisas vem muito prontas prá gente e depois se vai criticar em cima do que está pronto e já não pode ser mais mudado e mesmo que pudesse chegar a fazer uma programacão, quando chega a nīvel do secretārio, ele vai caneteando tudo, entāo eu acho que nāo existe nenhuma participação mesmo."

"É! Falar, pode. Só que não muda. Depois a discussão termina tipo assim: vai ficar estabelecido que vai ser uma vez por més como tinha dito. E termina por aī." (da forma como foi narrado, lembra o caso de Henry Ford e sua discussão com os gerentes para decidir a cor dos carros a serem fabricados: quando os gerentes foram chamados para opinar e sugeriram novas cores e Ford que tinha tradicional cor preta, após ampla discussão, na manhã seguinte, quando todos os gerentes aguardavam uma resposta, ele mandou dizer que concordava com a proposta, mas que os carros continuariam tendo a cor preta) 49 .

Os enfermeiros entrevistados pareciam desconhecer o poder, que deveria ser considerado como categoria de análise, quer pela sua escassa formação em ciências administrativas, quer pela pouca experiência de trabalho ou por ser recente a discussão do Poder em nosso meio, tanto no planejamento, como na administração.

A pouca participação na programação, a falta de autonomia e centralização, relacionadas pelos enfermeiros entrevistados, como fatores dificultantes do seu desempenho, poderiam ser superados ou entendidos, se esforços fossem feitos na busca de participação. .

Nesse conceito de participação estão subassumidas questōes como a distribuição de poder, autoridade e de propriedade, bem como mecanismos de coordenação, integracão e processo de tomada de decisão.

No Brasil, obstáculos impedem uma efetiva particīpacão, porque as relaçōes de trabalho reproduzem as condiçóes mais gerais da sociedade: hábitos e costumes autoritários, nepotismo no preenchimento dos cargos, prevalecendo as relações pessoais sobre as impessoais e uma sociedade de individuos carentes como cidadãos. Muitas vezes, o discurso institucional e político prega a participação, mas o que se observa é que não existindo sobre a forma de negociação coletiva, comitê de empresa, co-gestão e autogestão, destinados aos trabalhadores coletivamente (participacão indireta), ela è mais uma ação pessoal, psicolōgica, não distribuindo poder, mas o sentimento de estar engajado em uma obra ou ação entusiasman$\mathrm{te}^{81}$.

As vantagens de se utilizar esta tecnologia, segundo MENDONCA ${ }^{81}$, centrada em técnicas de grupo que propiciam a distribuição 
do poder, da autoridade e de propriedade, permitindo no processo de trabalho a formulação de objetivos, resoluçāo de problemas e mudanças organizacionais, reduzindo a alienação do trabalhador, pela ação coletiva resultante do processo necessário ao seu desenvolvimento.

As formas de participação podem ser desenvolvidas de forma pragmática ou sem uma posição ideológica.

A posição ocupada pelos enfermeiros, chefia de postos ou do pessoal de enfermagem, nas secretarias e departamentos de saúde - não indicam vir acompanhada de um. poder dentro da organização, seja èle técnico, administrativo ou politico, categorias descritos por TESTA apud RIVERA 105 com sua proposta do pensamento estratégico.

Para MALICK 69 "administrar sem poder termina sendo um trabalho rotineiro, pouco criativo, desgastante... Para a implantação de qualquer proposta se requer relações adequadas entre o administrador, as forças organizadas (internas e externas à organização) e as pessoas."

\subsubsection{Participaçāo Comunitāria}

TABELA 14 - Nümero e porcentagem de participaçāo de enfermeiros em atividades com a comunidade, em 22 municipios do Paraná, 1988.

\begin{tabular}{lrr}
\hline \hline PARTICIPACÃO COMUNITĀRIA & No & $\%$ \\
\hline Sim & 66 & 56,4 \\
Não & 46 & 39,3 \\
Sem informação & 5 & 4,3 \\
\hline T O T A L & 117 & 100,0 \\
\hline \hline
\end{tabular}

Mais da metade dos enfermeiros entrevistados afirmou desenvolver alguma atividade com a comunidade.

As atividades relacionadas como comunitārias foram:

a) Reuniões com a Associação de Moradores.

"... aqui tem 4 associaçōes de moradores, a gente tem reuniāo mensal com eles, assim meio administrativas... tirar düvidas em relação as atividades do Centro de Saúde."

"Esse Centro de Saúde tem uma história muito interessante, quem conseguiu o Centro de Saúde foi a comunidade... eles participam realmente, eles vên, a gente tem uma comissão de saüde. 0 psvo procura, quando tem alguma reclamaçāo, eles ven direto falar com a gente..." 
b) Cursos com participação de voluntārios.

"... jā teve gente que veio se prontificar pra ensinar o curso de enxoval pra bebê, para gestantes."

c) Palestras a grupos.

"... eu participo na forma de palestras..."

d) Treinamento de promotores de saúde ou utilização de voluntários.

"... nōs temos um grupo de 5 promotores de saúde, eles atuam hā dois ou mais anos, nós temos uma área de abrangéncia bastante grande."

"... aqui tem determinadas pessoas que sempre estão no Posto, trabalhando voluntariamente, inclusive ajudando na limpeza."

e) Controle das atividades pelas moradoras.

"... assim! o posto num dia, noutro dia, jā estava lā a associação de moradores que é tocada por mulheres... Elas passam uma vez por més no posto pra fiscalizar. (Verificar se não está faltando medicamentos, pessoal)."

f) Seleção de agentes de saüde. avaliação."

"... ela (população) escolhe os candidatos para depois passar por uma A participação apresenta-se com uma multiplicidade de enfoques e estratégias.

Os profissionais assinalam como participação comunitäria simples atividades de educação em saūde, como palestras a grupos da comunidade e para alguns o enfoque era o desenvolvimentista, da década de 50 , onde voluntários, frações da classe trabalhadora, são mobilizados, através de trabalho gratuito, para ajudar em atividades, que seriam de competéncia dos serviços de saüde ${ }^{9,} 126$.

A participação democrática ${ }^{53}$, em que è oportunizada a ingeréncia comunitária na tomada de decisão e na execução dos programas, era desenvolvida em postos de saúde, quando os entrevistados citam a participação das associações de moradores na construção de postos e na avaliação das suas atividades.

Os serviços de saúde, a nível local, se constituem muitas vezes em estruturas anti-participativas pelo carāter autoritário, com que tentam plantar as atividades e as relaçōes assimētricas, que se estabelecem entre os técnicos (detentores do saber) e a comunidade (destituída de informação para poder opinar e contrapor) ${ }^{109}$. 0s enfermeiros tendem a reproduzir essa relação como representantes que são, em seus postos de tra- 
balho, como chefes e supervisores, das diretrizes politicas e organizacionais das secretarias ou departamentos de saūde." 62 . Por outro lado, a carga horária insuficiente, para enfermagem de Saūde Püblica, durante a graduação, e locais de estāgio, sem desenvolver atividades de participacão comunitāria, refletem-se nas concepções e ações pouco avançadas e distorcidas da participação comunitária.

\section{Associação entre as atividades desenvolvidas, a formação profissional e a organização dos serviços.}

QUADRO 12 - Relação entre as atividades desempenhadas por enfermeiros e servicos organizados e não organizados, em 22 municīpios do Paraná, 1988.

\begin{tabular}{lccc}
\hline & \multicolumn{3}{c}{ SERVICos } \\
\cline { 2 - 4 } ATIVIdDADES & $\begin{array}{c}\text { Organiza- } \\
\text { dos }\end{array}$ & $\begin{array}{c}\text { Não Organiza- } \\
\text { dos }\end{array}$ & Z \\
\hline Supervisão & 61 & 24 & $2,5327 *$ \\
Treinamento de Pessoal & 43 & 16 & $2,5439 *$ \\
Consulta de Enfermagem & 4 & 15 & 3,9634 ** \\
Participação Comunitäria & 37 & 29 & 1,3855 \\
Participação na Programação & 29 & 14 & 1,0005 \\
\hline
\end{tabular}

* $P_{1}>P_{2}$

** $P_{1}<P_{2}$

Aplicando-se o teste $Z$ para proporção, ao nivel de significància de $1 \%$, concluiu-se que:

- em relação à supervisão e ao treinamento de pessoal, existe uma forte evidéncia de que a proporcão de enfermeiros, que desempenhavam estas atividades nos serviços de saúde organizados, é maior do que nos serviços não organizados.

- em relação à consulta de enfermagem, existe uma forte evidéncia de que a proporção de enfermeiros, que desempenhavam esta atividade nos serviços organizados, é menor do que nos serviços não organizados;

- em relação à participacão comunitária e participação na programação, existe uma forte evidéncia de que essas atividades independiam da estrutura da organização.

Esses achados demonstram as discussōes ao longo desse trabalho, em que a consulta de enfermagem era atividade desenvolvida como 
proposta em dois municīpios, no oeste paranaense, com absorcão de uma mesma escola, e em um deles, a relação entre enfermeiros e atendentes era de um por um, em zona urbana, diferente de todos os outros e com uma lógica que contradiz as organizacões em nossa sociedade. 0 processo de produção, mesmo entre os prestadores de serviço, é fragmentado, sendo indesejāvel que um trabalhador detenha todo o conhecimento. A forca do trabalho é constituīda de categorias ocupacionais com um baixo salärio e camadas médias. Essas ültimas tem o poder sobre os demais trabalhadores, funcionando como mediadores da administracão, sob a forma de controle, comando e organização, não cabendo a esses profissionais, em nosso caso, os enfermeiros, em sua maioria supervisores, executarem atividades não relacionadas a sua função ${ }^{47}$.

0 resultado da aplicação do teste $Z$, para a relação entre os serviços organizados e participação comunitária e na programação, ao mostrar que essas independem da organização, sugere que as variāveis que compuseram o indicador "serviço organizado", parecem em nossa op̃inião, inadequadas para evidenciar esta associação.

QUADRO 13 - Relação entre as atividades desempenhadas pelos enfermeiros e escolas de graduação, em 22 municīpios do Paranā, 1988.

\begin{tabular}{|c|c|c|c|c|c|c|c|}
\hline \multirow[b]{2}{*}{ ATIVIDADES } & \multicolumn{7}{|c|}{ ESCOLAS } \\
\hline & UEL & $\begin{array}{l}\text { CESU- } \\
\text { LON }\end{array}$ & $\begin{array}{l}\text { FEDE- } \\
\text { RAL }\end{array}$ & $\begin{array}{l}\text { CATŌ- } \\
\text { LICA }\end{array}$ & $\begin{array}{c}\text { FECI - } \\
\text { VEL }\end{array}$ & UEM & Outras \\
\hline Supervisão & 24 & 08 & 13 & 28 & 05 & 04 & 07 \\
\hline Treinamento pessoal & 11 & 05 & 10 & 26 & 03 & 00 & 04 \\
\hline Consulta Enfermagem & 1 & 00 & 01 & 02 & 11 & 00 & 04 \\
\hline Part. Comunitāria & 11 & 03 & 09 & 20 & 13 & 03 & 07 \\
\hline Part. Programação & 13 & 01 & 11 & 18 & 03 & 00 & 05 \\
\hline
\end{tabular}

Aplicando-se o teste $Z$ para proporção ao nivel de significância de $5 \%$, existe uma forte evidéncia de que:

- A proporção de egressos da FECIVEL apresentou diferenças significativas em relação às outras escolas, na maioria das suas atividades, exceto para a participação comunitária com os egressos da Universidade Federal do Paraná; na participação em programação com os egressos da Universidade Católica do Paraná e CESULON; e no treinamento de pessoal com os egressos da Universidade Estadual de Lonidrina.

A FECIVEL, dentrodas escolas estudadas, mostrou di'ferenças no processo de formação dos seus alunos, que eramabsorvidos em sua maioria em 
dois municipios, ocupando não só cargos dentro do nível local, mas em nível central, tendo oportunidade de determinar as caracteristicas tecnológicas do trabalho a ser desenvolvido. 0 pouco tempo de formado, a vivéncia em único campo de prática, impedindo de estabelecer padrōes de réferéncia (que permitiriam questionar a prática e o ensino), o maior isolamento de uma escola no sudoeste do Estado (distante de centros de influéncia como São Paulo e Ribeirāo Preto, como è o caso das escolas da regiāo Norte do Estado) e a sua fundação recente sugerem que os egressos dessa escola não segmentassem o processo de formação com o campo de prätica.

\section{Avaliação e sugestōes para a disciplina de Saúde Pública}

TABELA 15 - Número e porcentagem de enfermeiros segundo a contribuicão teórica da disciplina de saúde pública, no desempenho atual, em 22 municīios do Paraná, 1988.

\begin{tabular}{lcc}
\hline \hline CONTRIBUICÃO TEÓRICA & № & $\%$ \\
\hline Näo & 49 & 41,9 \\
Em parte & 34 & 29,1 \\
Sim & 27 & 23,1 \\
Sem informaçāo & 7 & 6,0 \\
\hline T O T A L & 117 & 100,0 \\
\hline
\end{tabular}

A teoria ministrada na disciplina de saüde püblica contribui com um percentual bastante baixo no desempenho atual do enfermeiro. Esses achados condizem com a anālise do conteúdo programático e carga horäria insuficientes, que impedem apropriarem-se de conhecimentos teóricos, que possibilitem uma reflexão sobre a ação e que resultem em uma prätica inovadora exigida por sua insercão, em postos de saüde municipais. Se esses se propõem a serem a porta da entrada do sistema e prestar assisténcia básica, o preparo desses profissionais está muito aquém do papel ampliado do enfermeiro, exigido por esse nível de atuação e pelas necessidades de saúde da população. 
TABELA 16 - Número e porcentagem de enfermeiros segundo a contribuição do estágio na disciplina de saúde pública no desempenho atual, em 22 municīios do Paranā, 1988.

\begin{tabular}{lrr}
\hline \hline CONTRIBUICÃO DO ESTÄGIO & No & $\%$. \\
\hline Sim & 40 & 34,2 \\
Não & 39 & 33,3 \\
Em parte & 32 & 27,4 \\
Sem informação & 6 & 5,1 \\
\hline T O T A L & 117 & 100,0 \\
\hline \hline
\end{tabular}

0 estägio na disciplina Enfermagem de Saúde Püblica teve uma avaliação mais favorāvel em relação a teoria, como apresentado na tabela no 20. Apesar das dificuldades em explicitarem quais foram as contribuições do estágio para o desempenho atual (falhas da memöria em separar os conhecimentos da disciplina de Saüde Püblica e outras afins e os adquiridos na graduação e posteriores a essa), os pontos positivos mencionados foram: maior tempo em estágio, características tecnológicas semeThantes entre o serviço e campo de estágio, turmas com poucos alunos, docentes comprometidos com o trabalho, aquisição de conhecimentos técnicos.

"... nós fizemos dois periodos iniciais em Saúde Püblica e no final do curso Administração em Saúde Püblica. Então deu para ter uma visão um pouco maior, dedicando um perīodo integral a essa atividade."

"... passamos por estágios em Postos de Saúde no município, não no Estado."

"... trabalhar com a comunidade, montar programas."

"Acho que a nossa formação foi uma coisa boa, porque foi uma turma pequena."

"... dentro do estágiopode-se ver muitas funçōes, como patologias delegadas e outras."

"Eu peguei fase que tinha boas enfermeiras de saúde pública, que acreditavam no que faziam, e o próprio currículo constava parte maior dessa disciplina."

Tanto a utilização de serviços prōprios, como o de outras instituiçōes, não contribuem para superar a dicotomia entire a teoria e a prätica.

Os serviços mantidos pelas instituições de saúde municipais 
e ou estaduais apresentam deficiēncias, que inviabilizam a construção de padrões de referência ampliados. A transformação se farā só quando se compreender o processo de trabalho em todas as suas dimensōes e a partir da $\bar{j}$ quais serão as necessidades educativas.

Nāo foram estudados os campos de prātica, mas trēs escolas mantinham postos de saúde e concentravam os estägios em seus servicos. As outras utilizavam-se de serviços estaduais e municipais.

QUADRO 14 - Número e porcentagem de sugestões para modificação da disciplina de saúde pública dos enfermeiros, em 22 municípios do Paranā, 1988.

\begin{tabular}{lcc}
\hline SUGESTÕES PARA MODIFICACÃ̃ & № & $\%$ \\
\hline Conteúdo & 87 & 74,3 \\
Carga horäria & 50 & 42,7 \\
Alocaçāo/Integração & 22 & 18,8 \\
Relacionamento Docente/Aluno & 14 & 11,9 \\
Capacitacão Docente & 6 & 5,1 \\
Outros & 4 & 3,4 \\
Sem informação & 9 & 7,6 \\
\hline
\end{tabular}

As sugestões foram agrupadas em grandes categorias acima descritas e o maior percentual foi quanto ao conteūdo, seguido pela carga horäria.

Pela análise da carga curricular da disciplina, em 1987, e quanto ao seu conteúdo, pode-se afirmar que os entrevistados estavam avaliando coerentemente, na medida em que as maiores proporcoóes de sugestões foram para conteúdo e carga horária.

\subsection{Conteúdo}

As sugestões para a disciplina quanto ao conteúdo incluiam mudanças curriculares, levando em contá o ciclo vital: do sadio para doente; inclusão de temas e práticas como Política Nacional de Saúde; Farmacologia dos medicamentos da Central de Medicamentos; Participação Comunitāria; Histōria da Saúde Pública; Gerenciamento e Administração dos Postos, com planejamento, programação; Epidemiologia; Integração Docente Assistencial com utilizaçāo da rede municipal; a prática voltada para atuação e não só observação ou atividades que não corressondem à reaiidade; ênfase em pediatria, ginecologia e obstetrícia e incentivo a pesquisa. 
Seguem-se os depoimentos:

"É reverter todo o quadro, nós temos que ver as pessoas aqui fora, porque depois que elas estāo no hospital é até simples."

"Precisava haver uma disciplina que fosse mesmo polītica nacional de saúde para deixar os alunos inteirados do que está acontecendo em termos de saūde."

"A Universidade tem que ir para a comunidade. Verificar, fazer estudos dessa comunidade, trabalhar a parte de saúde pública mesmo, de epidemiologia, diagnóstico de saúde local e traçar um perfil do profissional em saúde pública en cima das necessidades de saúde dessa populaçāo em relação à saūde."

"... que fosse dada mais énfase na Faculdade sobre as atividades mesmo do enfermeiro, que é avaliação da cobertura vacinal, avaliacão do programa."

"Bom, é meio complicado. Eu acho que a escola passa muito a questáo técnica. A técnica é importante para vocé saber como fazer um curativo, vacina e tal. Acho que isso é importante tambēm, mas a cobranca que vem do servico é mais em termos de administracão, de estar supervisionando e essa visão vocē não tem muito a nīvel de escola."

"Eu acho que a parte de planejamento è uma coisa de que eu estou sentindo muita falta."

"... noção de planta física, que é uma coisa básica, problemas de medicamentos, numa questão mais ampla, onde conseguir esses medicamentos, porque a gente acaba trabalhando com a aquisicão de equipamentos."

"Acho que principalmente nessa parte de educação em saúde."

"Vocé fica muito restrita ao serviço da escola que è modelo. Acho que poderia vir a conhecer um servico municipal de saúde, poderia diversificar essa prática ai."

"Se eu fosse aluna e me colocassem no Centro de Saúde da Prefeitura, eu aprenderia muito mais do que naquela época, do que ficar no Centro de Saúde da Secretaria do Estado, que nāo tem ligaçāo nenhuma com a comunidade, não tem participação, sō fica ali, atende consulta, manda embora, chegou a vacina faz, não tem controle, se faltou."

"Não só o aluno ficar observando fazer uma B.C.G., mas o fazer tambèm."

"Eu acho que o aluno tem todas as' condiçōes de fazer uma BCG, francamente." 
"Ser mais real... vocé aprende que tem que fazer e pegar uma paciente e em cima vocé trabalha uma manhã inteira, o que não é uma realidade, vocé sabe que não é isso. Se pegar uma paciente aqui e ficar com ela 2 horas em consultōrio, fazendo levantamento, a comunidade inteira cai de pau, porque tem outras todas para vocé atender."

"Ter um estágio mais real também, ficar mais tempo no Centro de Saúde, permanecer, fazer uma visita domiciliar, conhecer aquela população, criar vīnculo com aquela população e com aquela equipe, não ficar lá para fazer uma visitinha $e$ ir embora, pois a gente nāo aproveita nda com isso ... tentar fazer um plano em saúde pública.

Os conteüdos ministrados nas escolas estudadas mostram-se insuficientes, para que os seus egressos dominem o processo de trabalho na ārea de saūde pública, pois nos serviços de saúde os objetos de aprendizagem (conteúdo) são complexos, compreendendo aspectos da política, da técnica e da gerência.

\subsection{Carga horäria}

0 aumento da carga horāria sugerida è da disciplina de saúde püblica, para as disciplinas afins e para curso com 4 anos de duração.

"É o aumento da carga horária, porque a partir daī a própria programação seria favorecida, porque se aprende de tudo um pouquinho."

"Se o curso se estendesse mais, e você fizesse uma pressão para ter maior carga horāria, independente se não for ter opcāo que aumente a carga horāria de saúde pública, que é um absurdo, vocé passa dois anos vendo tudo de hospital e só no 70 perīodo tem saúde pública e um estágio de 15 dias, entāo è difícil.."

\subsection{Alocação e integração de disciplinas}

0 currículo fragmentado com disciplinas afins em diferentes periodos no sistema de crédito dificultava ao aluno a interligacão entre os värios conteúdos, e a sua posterior aplicabilidade.

"... dar uma visão maior ao aluno do que é realmente a saúde no inīcio do curso de enfermagem, porque vocé vai aprender o que è saúde, o que é comunidade, quando está se formando... Epidemiologia e Sociologia eu aprendi no comecinho e, quando eu cheguei, e precisava da disciplina lá, eu jā tinha até esquecido ou nāo valorizei na época."

"Eu tive conhecimento de ginecologia e obstetrīcia, que cipois eu ti- 
ve que transportar para a prātica de saúde püblica, só que eu nāo conseguia fazer esse transporte, porque as disciplinas eram tão fragmentadas e nāo havia interligação entre elas, que eu não conseguia me desempenhar bem."

"Acho que a saúde é um todo, então integrar doenças transmissíveis, integrar gineco-obstetricia, pediatria."

"Saúde pública, na minha opinião, ser ministrada no final do curso, poque vocé recebe saūde pública que è a primeira matéria que vocé tem, quando estā entrando no $2 \underline{0}$ ano da Universidade. Deveria ser uma matéria dada durante um tempo maior e no final do curso de graduação."

"A gente deveria optar, porque existe a Administraçāo de Enfermagem. Eu vou querer trabalhar em saúde pública? Então eu vou fazer Administração em Saúde Püblica."

\subsection{Relação Docente/Aluno}

0 excessivo número de alunos no estágio em uma escola por docente), supervisão docente menos próxima, maior liberdade para atuacão no campo de estágio, o relacionamento conflituoso com os funcionários dos serviços e a aferição da aprendizagem são as questões levantadas pelos ex-alunos.

"... a gente fazia estāgio com muitos alunos e os funcionārios não nos aceitavam."

"Eu acho que a gente deveria estar assim mais solta..."

"Na época que fiz estāgio, eu não tinha enfermeira na Unidade, tinha que ir e fazer. Queira ou não, a gente cria uma certa dependēncia..."

"Eu achava excelente a forma, com que eles avaliavam a gente, sō que eu sentia muita falta do feed-back."

\subsection{Capacitação docente}

Os docentes desvinculados do serviço e a sua formação especīfica na àrea foram também motivos para melhoria do ensino.

"O professor da Universidade devia ter mais contato com as Instituicōes de prestação de assistência."

"Professores com um pouquinho mais de especialização, não $s$ endo simplesmente graduados..." 
anälises feitas em anos recentes ou mesmo na história de 20 ou 30 atrás, nas propostas de mudanças curriculares dos enfermeiros, que buscam ajustes para a superação da separação entre o ensino e a prática ${ }^{5}$.

Essas dificuldades enfrentadas não são privilégio do enfermeiro brasileiro, mas guardadas as devidas proporções, também dos educadores e prestadores de servico, nos Estados Unidos e na Inglater$\mathrm{ra}^{42,} 77,124$.

A disciplina de saúde pública, no curso de graduação em relação aos currīculos mínimos, tem sofrido alterações que se demonstram e se refletem, na prática atual.

A Lei no $775 / 49$, de 06.08 .49 sobre o currículo, organizou o curso de enfermagem em 3 séries. A disciplina era ministrada com duração minima de 3 meses e o estágio poderia ser realizado em zona urbana ou ru$\operatorname{rat}^{45}$.

Em 1962, o novo currículo determinava o desaparecimento da disciplina de Saūde Pūblica do curso de graduação. A Associação Brasileira de Enfermagem pede revisão do parecer, solicitando a inclusão da disciplina como obrigatória, os conselheiros negam, com o argumento de um ano da especialização em saūde püblica, acrescentando no final: "No curso geral, as disciplinas de enfermagem terão em vista os aspectos de saúde pública, correspondente." Do mesmo modo a inclusão de Ciēncias Sociais é negada: "tal matéria não consta, como obrigatōria, no curso de medicina. Como exigī-10 no de enfermagem?... Como matéria complementar, as escolas de enfermagem poderão adotā-1a" 83 .

Os cursos são assim desobrigados de mostrar o que acontece com a população fora do hospital e entender a nossa sociedade.

A não obrigatoriedade da disciplina no currīculo minimo coincide com o declínio das açōes de saúde pública ${ }^{29}$. Declínio que se acentua na década de 60, quando começa a diminuição da participação do Ministério da Saüde no orcamento global da União, passando privilegiar a assistência individual, e não mais as ações de saúde pública, com a destinação de maiores recursos para a Previdencia. Com a crise financeira dessa instituicão é que se reativam as propostas racionalizadoras, como a descentralizacão dos aparelhos institucionais de saúde, que levam à municipalização.

A reforma curricular, atualmente vigente, (Lei 5540, art. 26 , de 28 de novembro de 1960 , e o parecer 163/72) tambēm não a incluem como obrigatöria 84 .

0 currīculo conservou-se linear e rigido 45 .

A reforma universitária, com a implantação do sistema de crēditos, foi uma proposta de expansão para a ampliaçäo de vagas no ensino superior, com acréscimo de custos mīnimos ${ }^{59}$. Para a enfermagem talvez a 
criação do básico, (criado para aproveitamento de vagas em cursos de menor procura) tenha sido o responsável, pelo menos em algumas escolas, pela diminuicão da carga do ciclo profissionalizante e, tendo como consequéncia, um profissional com pouco preparo para desempenhar as suas atividades präticas.

Mesmo nas escolas de enfermagem do Paraná, que mantēm a disciplina Enfermagem de Saúde como obrigatōria em sua grade curricular, com uma carga horária mīnima, (se dividirmos a carga horāria da prätica em dias de estāgio, o aluno passa 4 semanas em estāgio: na escola onde atuamos, o estágio corresponde a 17 dias üteis, em contraposição ao "antigo" que na Madre Léonie, em 1967, era de 3 meses), não atendendo a formação de um enfermeiro generalista e nem voltado para as necessidades da maioria da população.

0 conteúdo, face a essa carga horāria mínima, não tem a menor possibilidade de capacitar até em procedimentos básicos. Entre os procedimentos técnicos pode-se citar o B.C.G., que é vacina obrigatória no 10 ano de vida. Tendo em vista o número de postos de saúde existentes nos municipios, o pessoal auxiliar com treinamento curto e a pequena proporção de enfermeiros com Habilitação em Saūde Pública para o Paraná, seria necessārio que o enfermeiro, ao sair da graduação, estivesse capacitado para executar tal procedimento na rede de postos municipais.

os argumentos da necessidade de um número de aplicacoóes para ser um profissional em condições de aplicação devem ser repensados como uma tradição, que tem suas origens no treinamento do teste tuberculinico, feito pela Divisão Nacional de Tuberculose, quando da introdução das hoje antigas seringas de metal para aplicação de P.P.D.. Este treinamento foi feito por uma enfermeira sueca para os enfermeiros, que seriam multiplicadores da técnica, exigindo 500 aplicaçōes e leitura dupla-cega com leitora padrão. O B.C.G. segue o mesmo rigor no treinamento, talvez por ser uma das poucas técnicas pela via intra-dérmica. Esse número exigido pelo treinamento pode ser diminuido, tendo em vista a habilidade das alunas e, de outro lado, as características de um pais, que tem altos indices de tuberculose.

Ao docente cabe facilitar essa aprendizagem, selecionando como campo de prätica não só postos, que, por terem área delimitada, apresentam baixa demanda para a vacina B.C.G., alguns esperando ter um número maior de crianças, para não inutilizar doses de vacina, marcam um dia no més ou na semana.

O B.C.G., como as outras vacinas, è procedimento especifico da Saūde Püblica e também a sua via de aplicação, intra dérmica, è rara de acontecer em outros campos de estágio. 
A auséncia de temas com Política Nacional de Saūde, que ampliam a compreencão do sistema de saūde, também são apresentados como sugestão para a melhoria do desempenho.

As propostas para a correcão dessas disfunç̃es entre o ensino e a prática é preocupação ao longo da nossa histōria. DOURADO 44 em 1946 assinalava: "a comunidade deve oferecer oportunidade de ensino dos fatores sociais e econômicos que influenciam a doença e a saūde, não somente no fim do curso, mas desde o período pré-clinico" ou quando em 1952, ALCANTARA 5 afirma: "As nossas enfermeiras recém-formadas são obrigadas a aceitar postos de chefia em serviços hospitalares e de saūde püblica, ou cargos de ensino em escolas de enfermagem, para os quais não estão preparadas, decorrendo dessa situação frustração por parte das enfermeiras e pouca eficiência nos serviços..."

"Todos precisam compreender que o ensino de uma escola de enfermagem não se restringe a uma acumulação de informações novas e nem $\bar{a}$ aquisição de habilidades manuais. A escola deve desenvolver no estudante a capacidade de pensar, de comunicar-se, de discriminar valores humanos $e$ de fazer julgamento."

PINHEIR0 99 , no VI Congresso Brasileiro de Enfermagem, propondo mudanças curriculares, constata: "Do estudo do currículo seguido nas escolas de enfermagem e da observação das funções, que nossas enfermeiras estão exercendo, que conclusão tiramos? que quase todas nossas diplomadas, numa maioria esmagadora, estão exercendo funçōes para os quais não foram preparadas. Parece um paradoxo, mas e-uma realidade... Por isso mesmo $\bar{e}$ que vimos propor aqui uma revolução: a de prepararmos enfermeiros chefes e supervisores em nossas escolas."

Recomenda que as escolas de enfermagem promovam a revisão curricular, procurando selecionar as atividades dos estudantes e eliminar as repeticões excessivas, afim de tornar possivel a inclusão, no currículo, de noções de Administracão, Pedagogia e Supervisão, acompanhadas da prātica correspondente.

As disciplinas foram incorporadas, mas parece que isso não resolveu a questão, porque os enfermeiros de hoje continuam com dificuldades em fazer o ajuste entre o que a escola ensina e o que o servico exige. Em 1978, PAIM e col. 97 acreditam que as propostas de extensão de cobertura com regionalização dos serviços é a oportunidade de se pensar em inovacões no ensino, condicionadas por uma nova prática.

SILVA ${ }^{113}$, estudando o marco conceitual e estrutural dos currículos de enf srmagem de 1920 a 1970 , encontra-os voltados para os modelos tradicionalisias e aponta para a década de 80 algumas propostas reformistas, como a ideologia voltada para a afirmacão do status profissional, definição de 
papēis e busca de autonomia, integração docente assistencial, extensão de cobertura de servicos, determinação do mercado pelo Ministério da Previdécia e Assisténcia Social.

0 final da década nos encontra na situação retratada pelo presente estudo quanto à prática e formação em saūde pública, sem conseguir superar essas questões, que permeiam tanto a escola como os servicos: a necessidade de forjar novos perfis de liderança, desenvolvimento de capacidades técnicas para a geréncia dos serviços, assim como de aspectos clīnicos e epidemiológicos para a assisténcia individual e coletiva 86,87 .

A dispersão e o pequeno número de profissionais nos municí pios pesquisados podem dificultar a sua dispensa para curso de educação continuada em centros maiores, onde estão localizadas as escolas de enfermagem e as regionais de saūde; tendo em vista essa conformação, é necessārio que os ajustes sejam feitos nos currículos durante a graduação.

Sabe-se que a segmentação entre a escola e a prática parece dificil de ser superada com reformulaçóes curriculares, pois mesmo a enfermagem na Inglaterra, onde no curso de 3 anos, o estudante è ao mesmo tempo aprendiz e trabalhador e passa de 6 a 8 semanas em enfermarias, os estudantes recebem uma visão idealizada dos enfermeiros educadores, mas esperando trabalhar de forma diferente, reconhecendo e acatando o fato de que o que é ensinado pela escola não tem semelhancas com o que encontra nas enfermarias 77 .

A Universidade brasileira em crise, "como Instituição corporativista que $\bar{e}$, tem dificuldade em distinguir o saber real do saber imaginario... Em geral trata-se de uma universidade mal aparelhada, com laboratōrios ineficientes e bibliotecas paupērrimas. O recrutamento forsado entupiu-a com professores incompetentes", devido ao ciclo expansionista de $1968^{55}$.

Dessa anälise mais global que o autor faz, 0 que se pode dizer de uma das escolas que tem apenas 3 enfermeiras em seu corpo docente?

A disciplina de Saúde Pública, em um Estado com $46,2 \%$ da população economicamente ativa, recebendo até dois pisos salariais, deveria ter aderéncia a esta realidade, mas isso não ocorre, pois a escola conforma-se às necessidades do capital, que neste país parece não se preocupar com esta população 51 .

Frente a esse quadro, 0 ajuste não pode ser só curricular com capacitação dos docentes, mas parece ser a medida que ao seu alcance e que a curto prazo reverterá em melhoria para a formação de enfermeiros no Es iado do Paranā.

As sugestões dos egressos quanto à carga horāria, conteū- 
do, relação docente/aluno, capacitação dos professores devem remeter às escolas às discussōes sobre o currículo e as mudanças necessárias para o egresso exercer as suas funçōes em postos de saúde municipais. Os participantes dos seminärios para elaboração de um novo currículo minimo reinvidi cam transformações, apontam parà a compreensão da conjuntura do pa.js, a Política Nacional de Saüde, os princípios da Reforma Sanitária, a Lei do Exercicio profissional, énfase no compromisso social do enfermeiro, aumento do curriculo em horas e anos, extinção das habilitaçōes indicando revisão das àreas de ciēncias biológicas, humanas e de saüde püblica. Caberá a cada curso delinear o perfil, marco conceitual, o trabalho com a comunidade, estratégias para integração docente-assistencial, articulação do pré-profissional com o profissional e da pesquisa com a pós-gradua cãa ${ }^{12,122}$. 
v. CONCLUSŌES 
Quando se considera a integração proposta pela OPAS alicercada no tripé constituido pelo sistema formador de recursos humanos, pelo processo de trabalho e pelo papel do Estado na prestação de serviços nos postos de saúde de 22 municípios do Estado do Paraná, onde existem enfermeiros, os dados colhidos indicam que a prestação de serviços ainda é feita de maneira bastante elementar. Detectam-se insuficiências nos trēs componentes envolvidos na integração, o que acaba por caracterizar os servicos como pouco integrados às präticas modernas sugeridas ao exercício da enfermagem em Saúde Püblica. Na caracterização dos enfermeiros dos postos de saúde e do aparelho formador, grande número das informações obtidas reforcam este ponto de vista, a saber:

- $91,4 \%$ dos enfermeiros graduaram-se nas escolas do pröprio Estado do Paraná, sendo que $35,8 \%$ formaram-se nos últimos 2 anos. Isto mostra um grande contingente de recém-graduados, com pouca experiēncia profissional. Além disso, apenas $42,7 \%$ dos enfermeiros tinham algum curso de especializacão lato sensu em Saúde Pública;

- Mais da metade dos enfermeiros atuavam havia menos de 2 anos nos servicos. Frequentemente eram os primeiros enfermeiros do servico, não contando, pois, com a orientação de enfermeiros mais experientes. Quando se estuda a carga horäria desses profissionais, vē-se que $95,8 \%$ tinham uma carga horäria mỉnima de $30 \mathrm{~h}$. Apenas $12,0 \%$ dos enfermeiros não exerciam atividades externas aos postos de saüde. A relação enfermeiros/ auxiliares mostrou grande variação: desde 1:1 até 1:23; também foi grande a variação enfermeiros/postos de saúde sob sua supervisão: desde $1: 1$ até $1: 12$;

- As atividades administrativas intrapostos citadas com maior frequência foram: supervisão $(76,1 \%)$, organização do serviço $(47,0 \%)$, elaboração de relatórios/escalas $(39,1 \%)$, coordenação de programas $(31,6 \%)$ e chefia do posto de saúde $(25,6 \%)$. Em relaçãoàs atividades assistenciais, $83,8 \%$ dos enfermeiros faziam o atendimento de enfermagem. Atividades encampadas recentemente pela ASP, como consulta de enfermagem e visita domiciliar, eram desempenhadas por baixas porcentagens de enfermeiros $(16,2 \%$ e $13,7 \%$, respectivamente). Dentre as atividades educativas, $50,4 \%$ dos enfermeiros exerciam o treinamento de pessoal e de grupos, geralmente constituídos, os ültimos, por setores específicos da clientela. As atividades de pesquisa foram referidas por apenas $4,2 \%$ dos enfermeiros. Esta atividade nāo é considerada prioritāria nos postos de saūde, pois os mesmos têm como principal função a prestação de serviços. No entanto mostra que pelo menos alguns postos têm uma estrutura que se destaca dos demais, permitindo tal 
atividade. Dentre as atividades externas aos postos de saúde as referidas com maior frequência foram: participação em reuniōes $(54,7 \%)$, programas com creches e/ou escolas $(40,1 \%)$, coordenação em nível central $(10,2 \%)$ e participação em comissōes $(10,2 \%)$;

- Quando se estuda a organização dos serviços considerandose a existēncia ou nāo de programas, atribuiçōes do enfermeiro e do auxiliar de Saúde e Manual de Normas e Procedimentos, verifica-se que menos de $1 / 3$ dos municipios dispunham desses instrumentos. As atribuiçöes dos enfermeiros foi o subítem encontrado com maior frequencia, em $50,0 \%$ dos servicos. Esses dados mostram que a maioria dos municípios não possuem uma organização mīnima em seus serviços de saüde;

- Dentre os fatores institucionais facilitadores do desempenho, os citados com maior frequencia foram: bom relacionamento dentro da equipe $(33,3 \%)$, apoio institucional $(31,8 \%)$, autonomia profissional $(10,2 \%)$ e existēncia de diretrizes políticas $(7,6 \%)$. A gama dos fatores institucionais dificultadores do desempenho foi muito grande. Destacam-se: planta física inadequada $(46,4 \%)$, insuficiência de recursos humanos $(36,6 \%)$, capacitação insuficiente de recursos humanos $(27,6 \%)$ e falta de medicamentos $(22,3 \%)$. É interessante observar que alguns fatores citados como facilitadores também o foram como dificultadores, como, por exemplo, a falta de relacionamento dentro da equipe $(11,6 \%)$ e a falta de autonomia $(8,9 \%)$;

- A prática e a formação profissional, quanto a escola de graduação, mostrou diferenças estatisticamente significantes para a maioria das atividades selecionadas (supervisão, treinamento de pessoal, consulta de enfermagem, participaçāo comunitāria e na programaçāo) para os egressos da Faculdade de Educação, Ciēncias e Letras de Cascavel (FECIVEL), em relação aos egressos das outras escolas, exceto quanto à participação comunitäria com os egressos da Universidade Federal do Paraná, participacão na programação com os egressos da Universidade Católica do Paraná e o Centro de Estudos Superiores de Londrina (CESULON) e o treinamento de pessoal com os egressos da Universidade Estadual de Londrina;

- A relação entre os servicos organizados e as atividades selecionadas (supervisão, treinamento de pessoal, consulta de enfermagem, participação comunitāria e participação na programação) mostrou-se estatisticamente significante, com forte evidéncia que a proporcão dos enfermeiros, que desempenhavam atividades de supervisão e treinamento nos serviços de saúde organizados, era maior do que nos serviços não organizados;

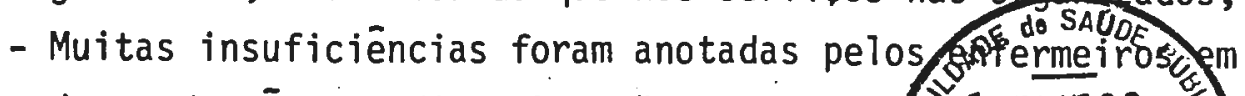
relação ao curso de graduação, na disciplina "Enfermagem d $41,9 \%$ dos enfermeiros classificaram o conteúdo teórico co שeibinede quadentaca suas präticas. Isso corresponde ao encontrado quando se an 
tas dessa disciplina. De fato, nenhuma escola apresentava temas voltados ao planejamento e programaçāo em saüde; pouca ènfase è dada às atividades administrativas. Por outro lado a pequena carga horária impede que temas importantes sejam incluỉdos. Também a adequação em relação ao estágio é considerada baixa: apenas $34,3 \%$ consideraram-na eficiente. Tais deficiēncias são percebidas por grande número de enfermeiros, que sugerem, como mudanças curriculares necessärias relativas ao conteüdo, aumento da carga horäria geral, e, especificamente à dedicada à temas como Administração, Politica Nacional de Saúde e Participação Comunitäria, entre outros.

- De modo geral o currículo não está adaptado às exigências do exercício profissional. Além das deficiências citadas, algumas präticas são ultrapassadas, enquanto que os novos avanços em áreas como Administração e Epidemiologia raramente são levados à discussão na disciplina. Isto é em parte ilustrado pela adoção do livro de LEAVELL \& CLARK em 5 escolas, - qual analisa a doença do ponto de vista ultrapassado da multicausalidade e não como um processo de caräter histörico e social.

- Os dados obtidos mostram que a qualidade dos servicos oferecidos estão aquém do desejado. Os fatores de insuficiência são detectados desde a formação dos enfermeiros nos cursos de graduação, contribuindo para que os mesmos saiam das escolas totalmente inexperientes, até os vários fatores dificultadores do desempenho apontados nos postos de saúde, englobando desde problemas de direção atē problemas de relacionamento dentro das equipes.

- Vē-se, portanto, que a melhoria desses serviços deve passar, necessariamente, por esses trēs niveis de integração. 
VI. REFERÊNCIAS BIBLIOGRĀFICAS 


\section{VI - REFERĒNCIAS BIBLIOGRÁFICAS}

1. ADAMI, N.P. Campos de prática de enfermagem de saúde püblica no Estado de São Paulo. São Paulo, 1972. [Tese de Doutorado - Faculdade de Saúde Püblica da USP.].

2. AHUMADA, J. et al. Problemas conceptuales y metodologicos de la programacion de la salud. Washington, Organizacion Panamericana de la Salud, 1965. (OPAS - Publicaciōn Científica, 111).

3. AIS: uma estratégia para as transformaçōes. Rev. Espaco para a saúde, $1: 25,1989$.

4. Albuquerque, M.C. A enfermeira e a AIS no Paranā. [Apresentado à 6a Jornada Catarinense de Enfermagem, Florianópolis, 1986 - mimeografado].

5. ALCANTARA, G. de Currículo de escolas de enfermagem na sociedade: integracão da escola de enfermagem na sociedade. An. Enferm., $\underline{5}: 301-$ $8,1952$.

6. ALMEIDA, M.C.P. \& ROCHA, J.S.Y. 0 saber de enfermaem e sua dimensão prätica. São Paulo, Cortez, 1986.

7. ALVES, D.B. Mercado e condicões de trabalho da enfermagem. Salvador, Gräfica Central, 1987.

8. ALVES, M. Organização do trabalho na enfermagem. Belo Horizonte, 1991. [Dissertacão de Mestrado - Faculdade de Ciéncias Económicas da UFMG].

9. AMMANN, S.B. Ideologia do desenvolvimento de comunidade no Brasil.

5á ed. São Paulo, Cortez, 1985.

10. ARCH, M. \& GRAETZ, B. Work satisfaction, unionism and militancy amongst nurses. Community H1th Stud., 13:177-85, 1989.

11. ARNS, 0. Um relance histörico. Inform. ABEn., Curitiba, 3:1, 1979.

12. ASSOCIACÃO BRASILEIRA DE ENFERMAGEM. Sobre uma nova proposta de currículo minimo para a formação do enfermeiro. Brasīi ia, 1989. [mimeografado].

13. BARRENECHEA, J.J. et al. Implicaciones para la planificacion y administracion de los sistemas de salud: salud para todos en el año 2000. Colombia, Universidade de Antioquia, 1990.

14. BEDEJAN, A.G. et al. The relationship between role stress and jobrelated, interpersonal and organizational climate factors. J.soc. Psychol.; 113:247-60, 1981.

15. BITTEL, L.R. Supervisão eficaz. São Paulo, McGraw Hill, 1982.

16. BONJEAN, C.M. et al. Increasing work satisfaction through organizational change: a longitudinal stuiy of nursing educators. J. appl. behav. Sci., 18:358-69, 1982. 
17. BOEMER, M.R. et al. Proposta alternativa para produção científica de enfermeiros assistenciais. Rev. Esc. Enferm., S: Paulo, 24:21123, 1990.

18. BRAINARD, A.M. The evolution of public health nursing. Philadelphia, Saunders, 1922.

19. BRASIL. Lejs, etc. Lei no 7.498 de 15 de junho de 1986: dispöe sobre a regulamentação do exercīcio de enfermagem e dá outras providéncias. Diärio Oficial da União, Brasilia, 26 jun. 1986.

20. BUENO NETO, C. Composição da equipe dos centros de saúde da Prefeitura Municipal de Curitiba. Curitiba, Prefeitura Municipal de Curitiba, 1987.

21. BURLAMAQUE, C.S. et al. Avaliação da produçāo científica dos enfermeiros do Rio Grande do Sul. Rev. Gaücha Enferm., 7:157-79, 1986.

22. CALLAHAN, C. B. \& WALL, L.L. Participative management: a contingency approach. JONA, 17(9):9-15, 1987.

23. CAMARGO, A.P.S. et al. Situação da produção científica em enfermagem no Estado de Santa Catarina. Rev. Gaücha. Enferm., 7:180-98, 1986.

24. CARMEL, S. et al. Autonomy, job satisfaction and professional selfimage among nurses in the context of a physicians' strike. Soc. Sci Med., 28:1315-20, 1989.

25. CARTA de Montes Claros: muda saüde. Saüde Deb., 17:50-1, 1985.

26. CARVALHEIRO, J. da R. La investigación de necessidades de salud en relación con la prestación de servicios. Cuad. Méd. Soc., Rosario, (34): 15-23, 1985.

27. CAVANAGH, S.J. Nursing turnover: literature review and methodological critique. J.Advanc. Nurs., 14:587-96, 1989.

28. CEDENO, M. et al. Participación actual de la enfermera en la atividades comprendidads en el papel ampliado de enfermeira. Educ. Med. Salud, 2:196-208, 1979.

29. CENTRO DE ESTUDOS E PESQUISAS EM ENFERMAGEM. Associação Brasileira de Enfermagem. Simpósio: reflexōes sobre o processo de trabalho de enfermagem na organizaçāo dos serviços de saúde na sociedade brasileira, Brasilia, CEPEn/ABEn, 1987.

30. CEREZO, L.V. et al. El futuro de la enfermeria em América Latina.

Educ. Med. Salud, 13:428-40, 1979.

31. Chiavenato, I. Administracão de empresas. São Paulo, McGraw Hill, 1982.

32. Chiavenato, I. Administracão: teoria, processo e prática. São Paulo, McGRaw Hill, 1987.

33. CONCLUSÕES dos dois anos do grupo de saúde da AMEPAR. J. Saúde AMEPAR, 17:4, 1986. 
34. CONFERẼNCIA INTERNACIONAL SOBRE CUIDADOS PRIMĀRIOS DE SAŪDE, Alma Ata, 1978. Relatörio. Brasīia, OMS/UNICEF, 1979.

35. CONSELHO FEDERAL DE ENFERMAGEM/ASSOCIACC̃̃O BRASILEIRA DE ENFERMAGEM. $\underline{0}$ exercīicio da enfermagem nas instituicões de saüde do Brasil - 1982/ 1983: enfermagem no contexto institucional. Rio de Janeiro, 1986.

36. CONSELHO FEDERAL DE ENFERMAGEM/ASSOCIAC̄̃A BRASILEIRA DE ENFERMAGEM.

Forca de trabalho em enfermagem: o exercicio da enfermagem nas instituicões de saúde no Brasil - 1982/1983. Rio de Janeiro, 1985.

37. CORDONI JR., L. Medicina comunitäria: emergéncia e desenvolvimento na sociedade brasileira. São Pau10, 1979. [Dissertação de Mestrado Faculdade de Medicina da USP.]

38. CORDONI JR., L. Participação social em saúde: experiéncia do Paraná. In: Conferēncia Nacional de Saúde, 8ạ, Brasīila, 1986. Anais, Brasijia, Ministério da Saúde, 1986, p. 307-11.

39. CORDONI JR., L. Serviços municipais de saúde no Paraná: tendéncias e perspectivas. São Paulo, 1986. [Tese de Doutorado - Faculdade de Saúde Pública da USP.]

40. CURITIBA. Secretaria Municipal de Saúde. Manual de funcionamento dos Centros de Saúde. Curitiba, 1987. [mimeografado].

41. DALLARI, S.G. Municipalização dos servicos de saúde.. São Paulo, Brasiliense, 1985.

42. DEIMAN, P.A. et al. BSN education and PHN practice: good fit or Mismatch? Nurs. Outlook, 36:231-33, 1988.

43. DI LASCIO, C.M.D.S. Satisfação no desempenho profissional da enfermeira: estudo sobre necessidades psicossociais. Rev. Esc. Enferm., S. Paulo, 14:321-31, 1980.

44. DOURADO, H.G. \& DOURADO, R.G. Organização de escolas de enfermagem no Brasil. An. Enferm., S. Paulo, (18):21-25, 1946.

45. DUARTE, A.B. Visão histórica dos currículos de enfermagem. Cad. Trab. Cient., R. de Janeiro, 1:26-35, 1989.

46. ESTUDO comparativo da implantação e desenvolvimento das ações integradas de saūde - Estado do Paranā. Londrina, UEL/NESCO, 1991.

47. FISCHMANN, R. Trabalho e capital monopolista: contribuicão para o estudo da obra de H. Braverman. R. Fac. Educ., S. Paulo, 12:189-97, 1986.

48. FRANCO, L.H.R. de 0 . Consulta de enfermagem. COFEN, $1(8), 1989$.

49. FREIRE, P. Como trabalhar com o povo. São Paulo, Associação Paulista de Saúde Püblica, 1983.

50. FREIRE, P. Extensão ou comunicacão. Rio de Janeiro, Paz e Terra, 1980. 
51. FUndACÃo IBge. Pesq. Nac. Amost. Dom., Rio de Janeiro, 12(5):277, 1988.

52. GADOTTI, M. Ação pedagógica e prática social transformadora. Educ. \& Soc., (4):5-14, 1979.

53. GALLARDO, L.D. Algumas tendencias de la educación y participación comunitaria en salud en America Latina. Bol. Ofic. sanit. panamer., 96:314-25, 1984.

54. GERMANO, R.M. Educação e ideologia da enfermagem no Brasil. São Paulo, Cortez, 1984.

55. GIANNOTTI, J.A. A universidade e a crise. Novos. Est. CEBRAP., (10): $32-41,1984$.

56. GONCALVES, R.B.M. Tecnologia e organização social das präticas de

saúde: características tecnológicas do processo de trabalho na rede estadual de centros de São Paulo. São Paulo, 1986. [Tese de Doutorado - Faculdade de Medicina da USP.]

57. GORZ, A. Crïtica da divisão de trabalho. Säo Paulo, Martins Fontes, 1980.

58. HADDAD, J. Desarrollo educacional en Salud: perspectivas para el año 2000. Educ. Med. Salud., 20.448-57, 1986.

59. HUMPHRIS, G.M. \& TUNER, A. Job satisfaction and attitudes of nursing staff on a unit for the elderly severely mentally infirm with change of location. J. advanc. Nurs., 14:298-307, 1989.

60. INTEGRA do relatörio final da 8a CNS. Rev. Espaço para a Saúde, 1: 44-6, 1989.

61. JOHNSON, J.A. \& BERGMANN, C.L. Nurse managers at the brokers table:

the nurse executive role. JONA, 18(6):18-21, 1988.

62. KARSCH, U.M.S. Consumir assisténcia médica: um direito do cidadão

paulistano. In: COVRE, M. de L.M. org. A cidadania que não temos.

São Paulo, Brasiliense, 1986. p. 85-94.

63. KURCGANT, P. Liderança em enfermagem. São Paulo, EPU, 1991.

64. LAPORTE, J.R. et al. Epidemiologia do medicamento: principios gerais.

São Paulo, HUCITEC, 1989.

65. LINDQUIST, K. \& HART, K. How hospitals are respoding to the shortage. Am. J. Nurs., 88:1206-10,

66. LOPES, M.J. : Discurso proferido por ocasião da colação de grau em Enfermagem da turma 87/1 da Escola de Enfermagem da UFRS. Rev. Gaúcha Enferm., 9:125-27, 1988.

67. LOPES, M.J. O trabalho da enfermeira: nem püblico, nem privado feminino, doméstico e desvalorizado. Rev. bras. Elıferm., 41:211-17, 1988. 
68. MACEDO, C.G. de. Polïtica de recursos humanos en salud. Educ. Med. Salud, 20:415-23, 1986.

69. MALIK, A.N. Teoria da administração: uma perspectiva, 1990. [mimeografado].

70. MANSFIELD, P.K. et al. The job context index: a guide for improving the "fit" between nurses and their work environment. J.advanc. Nurs., 14:501-8, 1989.

71. MARCH, M. Educação sanitāria e cuidados de enfermagem a domicīlio. An. Enfer., 16:57-60, 1947.

72. MÁRQUEZ, P.V. \& ENGLER, R. Crisis y salud: retos para la decada de los 90. Educ. Med. Salud, 24:7-25, 1990.

73. MARSIGLIA, R.G. Medicina social: evolução de um campo de idéias e de präticas. Temas IMESC., 1:3-11, 1984.

74. MARTIN, G.M. \& OIKAWA, L.T. Municipalização da assisténcia à saúde em Cambé. Saúde Deb., 21:13-15, 1988.

75. MASCARENHAS; R.S. et al. Introduçāo à administração sanitāria. São Pau1o, Faculdade de Saúde Püblica da USP, 1972. [mimeografado].

76. MCDOWELL, H.H. Programa de enfermeras com funciones ampliadas para la atenciōn primaria de salud en el Caribe Central. Bol. Ofic. sanit. panamer., 96:425-38, 1984.

77. MELIA, K.M. Student nurse construction of occucpactional socialisation. Soc. Health and I11nes., 6:132-51, 1984.

78. MENDES, D. de D. Algumas considerações sobre o perfil do enfermeiro na função gerencial da assistēncia de enfermagem. Rev. Gaūcha Enferm., 9:67-72, 1988.

79. MENDES, E.V. A evolucão histörica da prātica médica: suas implicações no ensino, na pesquisa e na tecnologia médica. Belo Horizonte, PUCMG/FINEP, 1984.

80. MENDONCA, L.C. de. A participacão do cidadāo nas decisões da administração püblica. Rev. Adm. púb1., 18:175-82, 1984.

81. MENDONCA, L.C. de. Participação na organização: uma introdução aos

seus fundamentos, conceitos e formas. São Paulo, Atlas, 1987.

82. MERCER, H. La medicina social en debate. Cuad. Méd. Soc., Rosärio, (42):5-13, 1987.

83. MINISTÉRIO DA EDUCACÃO E CULTURA. Conselho Federal de Educação. Parecer no 271: currīculo do curso de Enfermagem; Aprovado em 19/10/62. Documenta, (10):54-60, 1962.

84. MINISTÉRIO DA EDUCACÃO E CULTURA. Conselho Federal de Educação. Parecer no 163/72, C.C.R.: currīculos. Aprovado em 26/01/72. Documenta, (135):261-64, 1972 . 
85. MINISTÉRIO DA PREVIDÊNCIA E ASSISTẼNCIA SOCIAL. Reorientacāo da assisténcia à saúde no àmbito da previdéncia social. 3á ed. Brasīilia, 1983.

86. MINISTÉRIO DA SAÚDE. A educacão continuada de enfermeiros no sistema único de saúde. Brasilia, Centro de Documentação do Ministério da Saúde, 1990.

87. MINISTÉRIO DA SAÚDE. Sistema único de saüde: diretrizes para formulacão de politica de recursos humanos. Brasilia, Centro de Documentaçāo do Ministērio da Saüde, 1989.

88. MOTTAZ, C.J. Work satisfaction among hospital nurses. Hosp. Health. Serv. Adm., 33:57-75, 1988.

89. NAKAMAE, D.D. Bases para o encaminhamento da questão do ensino de enfermagem. Sāo paulo, 1986. [Tese de Doutorado - Escola de Enfermagem da USP.]

90. NOGUEIRA, M.J. de C. Assisténcia primária: uma responsabilidade para a enfermeira brasileira. Rev. Esc. Enferm., S. Paulo, 17:89-105, 1983.

91. NOGUeIRA, M.J. de C. Ensino de Enfermagem Comunitäria em São Paulo.

Rev. Esc. Enferm., S. Paulo, 15:95-117, 1981.

92. NORMAS e critérios de competência: enfermeiras e enfermeiros do

Quebec. São Paulo, Cortez, 1989. (Cadernos de Enfermagem, 2).

93. NÜCLEO DE TECNOLOGIA EDUCACIONAL PARA A SAŪDE. Centro Latino-Americano

de Tecnologia Educacional para a Saúde. Fundação W.K. Kellogg. Re-

latório final do grupo de trabalho sobre a participacāo da enfermagem na atençāo primária de saúde. Rio de Janeiro, 1983.

94. NUNES, E.D. org. Juan Cézar Garcia: pensamento social em saúde na América Latina. São Paulo, Cortez, 1989.

95. ORGANIZACÃO PANAMERICANA DE LA SALUD. El papel de la enfermera e la atención primeria de salud. Washington, D.C., 1977. (Publicación Cientifica, n. 348).

96. ORGANIZAR a defesa das propostas dos municipios. J. Saüde AMEPAR, (26):1, 1987.

97. PAIM, L. et al. As inovaçöes no ensino superior de enfermagem face a assistēncia à saúde da população. In: Congresso Brasileiro de Enfermagem, 3, Belém, 1978. Anais, Brasilia, ABEn, 1978. p. 11-115.

98. PILARES, V. Recursos humanos: (des) consideracōes gerais. São Paulo, Nobel, 1991.

99. PINHEIRO, M.R.S. A inclusão da pedagogia, supervisāo e administração no currículo das escolas de enfermagem. An. Enfern., S. Paulo, 5: 319-33, 1952. 
100. PROGRAMA colaborativo de estudios sectoriales sobre recursos humanos. Washington, Organizacion Panamericana de la Salud, 1991 [mimeografado].

101. REID, V.V. La ensenanza basica de enfermeria para la atención primaria de la salud en el Caribe del habla inglesa. Educ. Méd. Salud, 3:284-301, 1984 .

102. RELATÕRIO final da reunião de trabalho sobre ações integradas de saúde. Saúde Deb., 17:23-4, 1985.

103. RELATÓRIO final do grupo de trabalho sobre organização dos servicos de saúde. [Apresentado ao 50 Enccintro Municipal do setor Saúde, Londrina, 1978 [mimeografado].

104. RIBEIRO, M.N.F. \& GOULART, S.F. História da pesquisa em enfermagem. Rev. Gaücha Enferm., 5:299-304, 1984.

105. RIVERA, F.J.U., org. Planejamento e programação em saúde: um enfoque estratégico. São Paulo, Cortez, 1989.

106. ROBERTS, D.E. Enfermeria de salud de la comunidad: conceptos y estratégias. In: Organizacion Panamericana de la Salud. Antologia de experiēncias em serviço y docencia en enfermeria en América Latina. Washington, d.C. 1980. p. 24-43. (Publicaciōn cientifica, 393).

107. ROCHA, S.M. de M. A puericultura e a enfermagem no Estado de São Paulo. São Paulo, 1985. [Tese de Doutorado - Escola de Enfermagem de Ribeirão Preto da USP.]

108. ROSEN, G. A history of public health. New York, M.D. Publications, 1958.

109. ROUX, G. de et al. Participacion social y sistemas locales de salud. In: Organizacion Panamericana de la Salud. Los sistemas locales de salud. Washington, DC, 1990. p. 28-49. (Publicación Cientifica, 519).

110. SANTOS, N.R. Novo profissional de saüde: aspectos da perspectiva em atenção primāria e regionalização. Rev. bras. Educ. med., 11:17$21,1980$.

111. SCHRAIBER, L.B., org. Programação em saúde hoje. São Paulo, Hucitec, 1990.

112. SECRETÁRIOS Municipais paulistas organizam colegiado e fazem sugestão. J. Saúde AMEPAR, 26:8, 1987.

113. SILVA, A.L.C. Marco conceitual e estrutura dos currículos dos cursos de graduạcão. In: Congresso Brasileiro de Enfermagem, 31, Fortaleza, 1979. Anais, Brasilia, ABEn, 1979. p. 107-14. 
114. SILVA. E.M. Supervisão em enfermagem: Anālise crítica das publicacões no Brasil dos anos 30 à dēcada de 80. São Paulo, 1991 [Dissertação de Mestrado - Escola de Enfermagem de Ribeirão Preto da USP].

115. SILVA, G.B. Enfermagem profissional: anälise crítica. São Paulo, Cortez, 1986.

116. SILVA, V.E.F. da. Manuais de enfermagem. In: ADMINISTRACÃO EM ENFERMAGEM, São Paulo, EPU, 1991. p. 59-72.

117. SILVEIRA, M.M. Municipalização dos serviços de saúde. RADIS, 1982 , p. 3-8.

118. SONIS, A. La investigacion de servicios de salud: problemas

actuales. In: Organizacion Panamericana de la Salud. Los sistemas locales de salud. Washington, D.C. 1990. p. 443-49 (Publicacion Cientifica, 519).

119. SOUZA, A.M. de A. et a1. Processo educativo nos servicos de saúde. Brasilia, OPS, 1991.

120. SOUZA, R.K.T. Relato da prātica de enfermagem na rede de atendiment básico a saúde no município de Cambé. Londrina, 1985. [mimeografado].

121. STEAGALL-GOMES, D.L. Identificação do enfermeiro na força de trabaTho de enfermagem de saúde püblica no Departamento Regional de Saúde de Ribeirão Preto. São Paulo, 1986. [Tese de Doutorado Faculdade de Saúde Pública da USP].

122. SUBSİDIOS para elaboração de uma proposta de currículo mínimo para a formação do enfermeiro. Rev. bras. Enferm., 41:179-82, 1988.

123. SUDS no Paranā. Rev. Espaço para a Saúde, 1:74-5, 1989.

124. TANSEY, E.M. \& LENTZ, J.R. Generalists in a specialized profession. Nurs Outlook, 36:174-78, 1988.

125. TEIXEIRA, S.M.F. Descentralização dos serviços de saüde: dimensões analiticas. Rev. Adm. Públ., R. de Janeiro, 24:78-99, 1990.

126. UGALDE, A. Las dimensiones ideológicas de la participacion comunitaria em Latinoamérica. Cuad. Méd. Soc., Rosario, (41):27-43, 1987.

127. VIEIRA, C. Enfermagem e atenção primária à saūde no Brasil: contribuição para uma crítica. [Apresentado ao grupo de trabalho sobre a participação da enfermagem na atenção primäria de Saúde, Rio de Janeiro, 1983 - mimeografado.]

128. WEAM, E. Obstetrícia e saúde püblica na Inglaterra. An. Enferm., São Paulo, (4):236-40, 1953. 
129. YUNES, J. \& CAMPOS, 0. 0 papel da Faculdade de Saúde Pública na formação de recursos humanos para a saúde. Rev. Saúde Pübl., S. Pau10, 18(n. esp.):61-6, 1984.

130. ZAROUR, D.M. et a1. Perfil da enfermeira na SSPS/PML. Londrina, Secretaria de Saúde e Promocão Social de Londrina, 1984. [mimeografado]. 
ANEXOS 


\section{ANEXO NO 1}

:GRESSOS DOS CURSOS DE ENFERMAGEM DO PARANĀ

TABELA 17 - Evolução do número de egressos dos cursos de enfermagem do Paraná, 1957 - 1987, Paraná, 1988.

\begin{tabular}{|c|c|}
\hline ANO & №. \\
\hline 1957 & 06 \\
\hline 1958 & 09 \\
\hline 1959 & 07 \\
\hline 1960 & 08 \\
\hline 1961 & 10 \\
\hline 1962 & 08 \\
\hline 1963 & 12 \\
\hline 1964 & 06 \\
\hline 1965 & 06 \\
\hline 1966 & 00 \\
\hline 1967 & 06 \\
\hline 1968 & 16 \\
\hline 1969 & 10 \\
\hline 1970 & 21 \\
\hline 1971 & 24 \\
\hline 1972 & 33 \\
\hline 1973 & 22 \\
\hline 1974 & 48 \\
\hline 1975 & 09 \\
\hline 1976 & 53 \\
\hline 1977 & 85 \\
\hline 1978 & 97 \\
\hline 1979 & 102 \\
\hline 1980 & 133 \\
\hline 1981 & 99 \\
\hline 1982 & 178 \\
\hline 1983 & 253 \\
\hline 1984 & 217 \\
\hline 1985 & 268 \\
\hline 1986 & 328 \\
\hline 1987 & 296 \\
\hline TOTAL & 2.369 \\
\hline
\end{tabular}




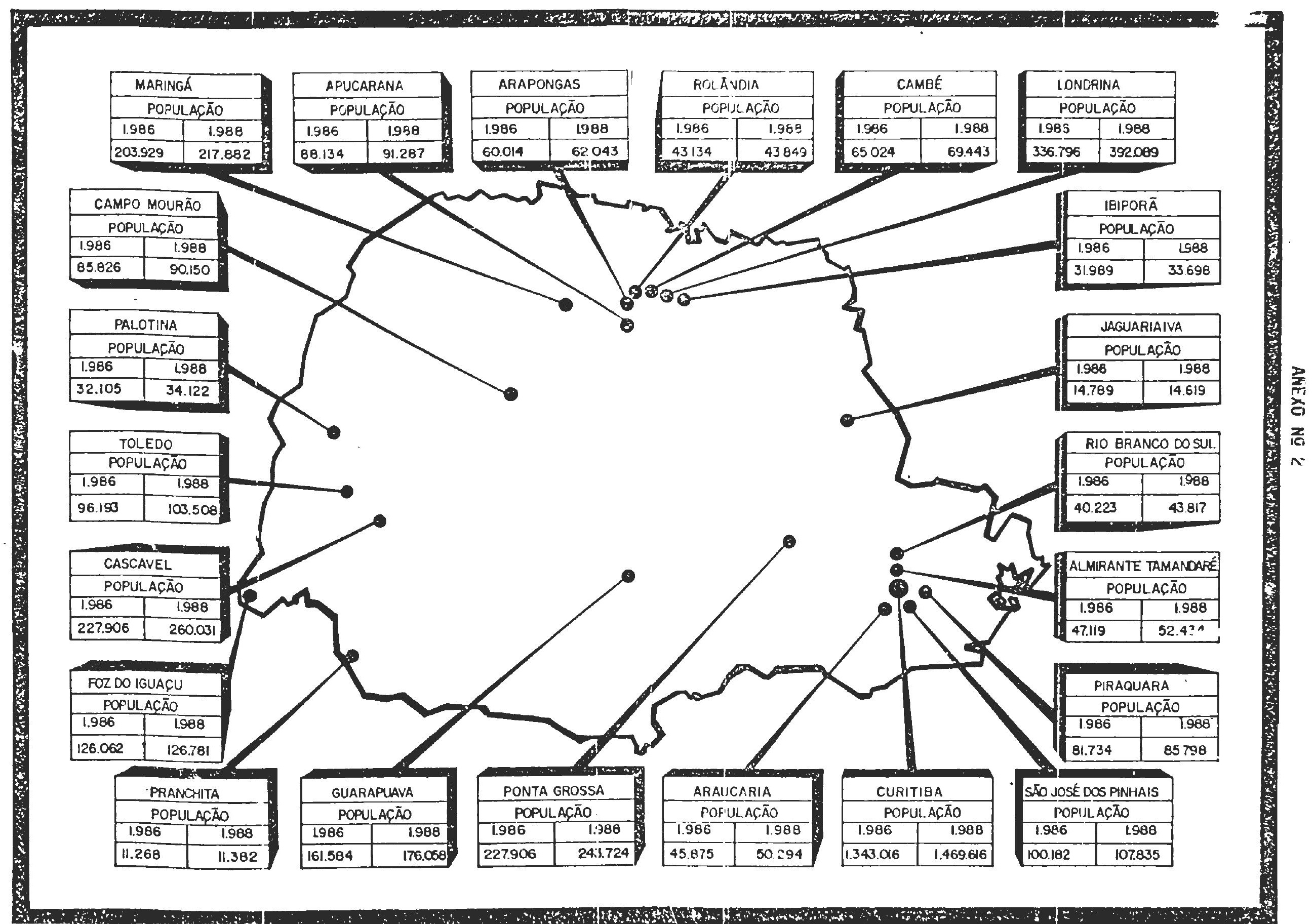


ANEXO No 3

TABELA 18 - Nümero de enfermeiros com vínculo empregatício nos postos de saúde dos municípios segundo número de entrevistados e existentes na rede, Paranä, 1988.

\begin{tabular}{|c|c|c|}
\hline MUNICİPIOS & ENTREVISTADOS & EXISTENTES \\
\hline Almirante Tamandaré & 02 & 01 \\
\hline Apucarana & 03 & 05 \\
\hline Arapongas & 02 & 02 \\
\hline Araucāria & 06 & 06 \\
\hline Cambē & 05 & 05 \\
\hline Campo Mouräo & 03 & 04 \\
\hline Cascavel & 11 & 16 \\
\hline Curitiba & 41 & 42 \\
\hline Foz do Iguacu & 03 & 03 \\
\hline Guarapuava & 02 & 02 \\
\hline Ibiporā & 02 & 02 \\
\hline Jaguariaiva & 01 & 01 \\
\hline Londrina & 15 & 16 \\
\hline Maringā & 04 & 05 \\
\hline Palotina & 02 & 02 \\
\hline Piraquara & 01 & 01 \\
\hline Ponta Grossa & 04 & 06 \\
\hline Pranchita & 01 & 01 \\
\hline Rio Branco do Sul. & 01 & 01 \\
\hline Rolāndia & 03 & 03 \\
\hline São José dos Pinhais & 01 & 01 \\
\hline Toledo & 04 & 06 \\
\hline$T O T A L$ & 116 & 128 \\
\hline
\end{tabular}


ANEXO № 4

ORGANIZAÇÃO DO - SERVICQO DE ENFERMAGEM

Municipio:

Atribuiçōes de Enfermeiros
[ ] $\operatorname{sim}$
[ ] Não

Atribuiçōes de auxiliares de Saúde
[ ] Sim
[ ] Não

Programas do Departamento ou Secretaria de Saúde
[ ] Sim
[ ] Não

Manual de Procedimentos e Rotinas no(s) Posto(s)
[ ] Sim
[ ] Não 
ANEXO 5

01) FORMULARIO $\mathrm{N}^{\circ}$

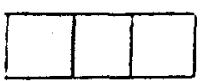

02) MUNICIPIO

03) GRADUAÇAO

04) HABILITAÇAO EM SAÚDE PÚBLICA

1 Sim 2 Não

05) ESCOLA HABILITAÇAO

06) ANO HABILITAÇAO

07) ESPECIALIZAÇAO EM SAÚDE PÚBLICA

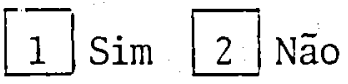

08) ANO DA ESPECIALIZAÇÃO

09) ESCOLA ESPECIALIZAÇÃO

10) JORNADA SEMANAL DE HORAS TRABALHADAS

11) JORNADA SENANAL DE HORAS CONTRATADAS

12) N DE POSTOS DE SAUDE ZONA URBANA

13) No DE AUXILIARES DE SAUDE ZONA URBANA

14) N: DE POSTOS DE SAUDE ZONA RURAL

15) N: DE AUXILIARES DE SAUDE ZONA RURAL

16) HORAS DE TRABALHO OU ATIVIDADES INTRA POSTO SEMANAL

17) HORAS DE TRABALHO EXTRA-POSTO SEMANAL

18) TEMPO DE TRABALHO NO MNICIPIO ANOS E MESES 
19) ATIVIDADES EXTRA POSTO DE SAUDE

1 Coordenação/assessoria nível central

2 Reuniōes

3 Cursos de formação

4 Conselho Comunitārio/CIMS

5 Curso de Especialização

6 Levantamentos Estatísticos

7 Assistência a creches/escolas

8 Outros

9 Sem informação

\begin{tabular}{|l|l|l|l|l|l|l|l|l}
\hline 1 & 2 & 3 & 4 & 5 & 6 & 7 & 8 & 9 \\
\hline & & & & & & & & \\
\hline
\end{tabular}




\section{ANEXO NO 6}

\section{(ROTEIRO PARA ENTREVISTA COM ENFERMEIRO DO POSTO)}

01. Quais as funçōes que vocē desempenha atualmente?

02. Descreva as atividades que desenvolve em cada uma das funçōes!

03. (Caso não tenha relacionado nas funçōes) Vocé tem alguma atividade de Prestação Direta de Assisténcia?

04. Como e quando è feita?

05. Relacione as atividades Extra-Postos de saúde que desempenha.

06. Existe participação comunitäria? (caso não tenha mencionado).

07. Como ela é feita?

08. E para vocé o que é Participação Comunitäria?

09. Existe(m) algum(s) fator(es) na Insituição que facilita(m) o seu desem penho?

10. Enumere-os ou descreva-os.

11. Existe(m) fator(es) na Instituição que dificulta(m) o seu desempenho?

12. Enumere-os ou descreva-os (capacidade instalada, recursos humanos, referéncia, etc.)

13. Como vocé avaliaria a assisténcia prestada pelo enfermeiro neste P.S. (numa escala de 0 a 10 que nota vocé daria para sua atuação e porque).

14. Em sua opinião, quais seriam as funções e atividades dos enfermeiros num P.S. em seu municipio?

15. Como vocé vè a sua participação na programação, das atividades de saúde, neste municipio? (numa escala de 0 a 10 qual o seu grau de participação).

16. A sua formação teörica em Saúde Pública durante a graduação contribui para o seu desempenho atual.

17. Vocé poderia relacionar na formação teörica em P.S. o que contribui para o seu desempenho atual?

18. A sua formação prätica em Saúde Pública durante a graduação contribui para o seu desempenho atual?

19. Relacione na sua formação prätica em Saúde Pública o que contribui para seu desempenho atual.

20. Em sua opiniāo, qual a formação teórica e prática que deveria ter recebido em Saúde Pública durante a graduação que facilitaria o seu desempenho? 


\section{ANEXO 7}

20) ATIVIDADES INTRA POSTO DE SAUDDE

1 Supervisão

2 Atendimento de Enfermagem

3 Consulta de Enfermagem

4 Grupos

5 Chefia do Posto

6 Treinamento A.S. em serviço

7 Coordenação de Programas

8 Relatōrios

9 . Visita Domiciliar

10 Organização do Serviço

11 Pesquisa Operacional

12 Outros

13 Sem informação

\begin{tabular}{|l|l|l|l|l|l|l|l|l|l|l|l|l|}
\hline 1 & 2 & 3 & 4 & 5 & 6 & 7 & 8 & 9 & 10 & 11 & 12 & 13 \\
\hline & & & & & & & & & & & & \\
\hline
\end{tabular}


21) PARTICIPAÇAO COMNITARIA

$\square$ Sim

$\square$ Não

Sem informação

22) CONCEPÇAO DA PARTICIPAÇAO COMUNITARIA

1 Tecnológica

2 Democrātica

3. Política-ideológica

4 Sem informação

23) EXISTE FATORES QUE FACILITAM O DESEMPENHO?
1 Sim
2 Não
3 Sem infun....ugum

24) FATORES QUE FACILITAM O DESEMPENHO

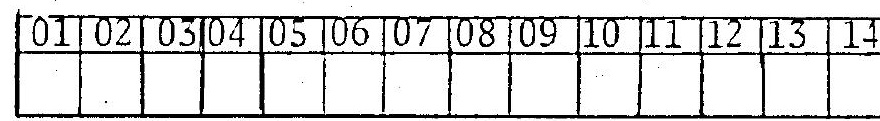

1 Integração comunidade/departamentos

2 Relacionamento inter-equipe

3 Supervisão

4 Capacitação

5 Transporte

6 Autonomia

7 Trabalho gratificante

8 Apoio institucional

9 Política de Saúde 
10 R.H. bom número

11 . Demanda não reprimida

12 Aceitação da comunidade

13 Outros

14 Sem informação

25) EXISTE FATORES QUE DIFICULTAM O DESEMPENHO

1 Sim

2 Não

3 Sem informação

26) FATORES QUE DIFICULTAM

1 Capacitação Insuficiente

2 Insuficiência de Recursos Humanos

3 Relacionamento inter-equipe

4 Motivação

5 Autonomia

6 Medicamentos

7 Equipamento

8 Transporte

9 Planta física/localização

10 Insuficiência de verbas

11 Carga horāria

12 Integração

Centralização

14 Comunicação 
15 Superrisão

16. Ausência de programação/planejamento

17 Ausência Divisão Enfermagem

18 Atividades Administrativas em excesso

19 Interferências políticas

20 Diretrizes da Instituição

21 Baixo salário

22 Alta demanda

23 Desvio de funções

24 Pouca valorização do trabalho

25 Trabalho em 02 níveis

26 Sistema de saúde e estrutura do país

27 Função do enfermeiro - definição

28 Cutros

29 Sem informação

\begin{tabular}{|c|c|c|c|c|c|c|c|c|c|c|c|c|c|c|c|c|c|c|c|c|c|c|c|c|c|}
\hline 01 & 02 & $03 \mid 0$ & 04 & 050 & 06 & 07 O & 08 & \begin{tabular}{l|l}
09 & 1 \\
\end{tabular} & 10 & \begin{tabular}{l|l}
11 & 1
\end{tabular} & \begin{tabular}{l|l}
12 & 1 \\
\end{tabular} & $13 \mid 1$ & \begin{tabular}{l|l}
44 & 1 \\
\end{tabular} & $5 \mid 1$ & 17 & 18 & 19 & 20 & 21 & 22 & \begin{tabular}{l|l}
23 & 2 \\
\end{tabular} & $4 \quad 25$ & 26 & & $28: 29$ \\
\hline & & & & & & & & & & & & & & & & & & & & & & & & & \\
\hline
\end{tabular}

27) A FORMAÇAO TEORICA EM S.PÚBLICA DURANTE A GRADUAÇAO CONTRIBUIU PARA O SEU DESEMPENHO ATUAL

1 Sim

2 Não

3 Parcial

4 Sem informaçāo 
28) A FORMAÇAO PRÁTICA EM SAÚdE PÚblica DURANTE A GRADUAÇAO CONTRI BUIU PARA O SEU DESEMPENHO ATUAL

$1 \mathrm{Sim}$

2 Não

3 Parcial

4 Sem informação

29) SUGESTOEES PARA A DISCIPLINA DE SAÚDE PÚBLICA QUE FACILITAM O DESEMPENHO

1 Relacionamento docente/aluno

2 Conteúdo \begin{tabular}{|l|l|l|l|l|l|}
\hline 01 & 02 & 03 & 04 & 05 & 06 \\
\hline & & & & & \\
\hline
\end{tabular}

3 Carga horäria

4 Alocação /integração disciplinas

5 Outros

6 Sein informação

30) PARTICIPAÇAO NA PROGRAMAÇAO DAS ATIVIDADES DE SAUdE

1 Não

2 Sim

\begin{tabular}{|l|l|l|l|l|}
\hline 01 & 02 & 03 & 04 & 05 \\
\hline & & & & \\
\hline
\end{tabular}

3 Parcialmente

4 Sem informação

31) CARGO

1 Enfermeira

2 Chefe de Posto 
EGRESSOS POR ESCOLAS DE ENFERMAGEM DO PARANĀ

TABELA 19 - Número dos Egressos da Escola de Enfermagem Madre Léonie - Pontifícia Universidade Catölica do Paraná, 1957-1987, Curitiba, 1988.

\begin{tabular}{|c|c|}
\hline ANO & № \\
\hline 1957 & 06 \\
\hline 1958 & 09 \\
\hline 1959 & 07 \\
\hline 1960 & 08 \\
\hline 1961 & 10 \\
\hline 1962 & 08 \\
\hline 1963 & 12 \\
\hline 1964 & 06 \\
\hline 1965 & 06 \\
\hline 1966 & Não houve formatura \\
\hline 1967 & 06 \\
\hline 1968 & 16 \\
\hline 1969 & 10 \\
\hline 1970 & 21 \\
\hline 1971 & 24 \\
\hline 1972 & 33 \\
\hline 1973 & 22 \\
\hline 1974 & 37 \\
\hline 1975 & Nāo houve formatura \\
\hline 1976 & 32 \\
\hline 1977 & 37 \\
\hline 1978 & 47 \\
\hline 1979 & 55 \\
\hline 1980 & 54 \\
\hline 1981 & 44 \\
\hline 1982 & 92 \\
\hline 1983 & 99 \\
\hline 1984 & 102 \\
\hline 1985 & 91 \\
\hline 1986 & 77 \\
\hline 1987 & 78 \\
\hline TOTAL & 1.049 \\
\hline
\end{tabular}


A14

TABELA 20 - Número dos egressos do curso de enfermagem da Universidade Estadual de Londrina, 1974-1987, Paranā. 1988.

\begin{tabular}{ll}
\hline ANO & № \\
\hline 1974 & 11 \\
1975 & 09 \\
1976 & 21 \\
1977 & 48 \\
1978 & 40 \\
1979 & 35 \\
1980 & 52 \\
1981 & 48 \\
1982 & 24 \\
1983 & 55 \\
1984 & 44 \\
1985 & 47 \\
1986 & 42 \\
1987 & 42 \\
\hline TOTAL & 518 \\
\hline
\end{tabular}


TABELA 21 - Numero de egressos do curso de Enfermagem da Universidade Federal do Paraná, 1979-1987, Paraná, 1988.

\begin{tabular}{ll}
\hline ANO & NO \\
\hline 1978 & 10 \\
1979 & 13 \\
1980 & 27 \\
1981 & 07 \\
1982 & 42 \\
1983 & 35 \\
1984 & 33 \\
1985 & 40 \\
1986 & 48 \\
1987 & 26 \\
\hline TOTAL & 281 \\
\hline
\end{tabular}


TABELA 22 - Nümero de egressos da Faculdade de Educação, Cienncias e Letras de Cascavel 1982-1987, Paranä, 1988.

\begin{tabular}{ll}
\hline ANO & No \\
\hline 1982 & 20 \\
1983 & 22 \\
1984 & 32 \\
1985 & 25 \\
1986 & 38 \\
1987 & 23 \\
\hline TOTAL & 160 \\
\hline
\end{tabular}


TABELA 23 - Número dos egressos do curso de Enfermagem da Universidade Estadual de Maringā, 1984-1987, Paranā, 1988.

\begin{tabular}{ll}
\hline ANO & No \\
\hline 1984 & 04 \\
1985 & 33 \\
1986 & 47 \\
1987 & 49 \\
\hline TOTAL & 133 \\
\hline
\end{tabular}


TABELA 24 - Nümero dos egressos do Centro de Estudos Superiores de Londrina (CESULON), 1983-1987, Paranä, 1988.

\begin{tabular}{ll}
\hline ANO & No \\
\hline 1983 & 42 \\
1984 & 02 \\
1985 & 32 \\
1986 & 52 \\
1987 & 57 \\
\hline TOTAL & 185 \\
\hline
\end{tabular}


TABELA 25 - Nümero dos egressos da Fundação Faculdade Municipal de Educacão, Ciências e Letras de Paranava i, 1986-1987, Paranā, 1988.

\begin{tabular}{ll}
\hline ANO & № \\
\hline 1986 & 24 \\
1987 & 21 \\
\hline TOTAL & 45 \\
\hline
\end{tabular}

